\title{
STUDIES ON THE METABOLISM OF RIBOFLAVIN IN ASHBYA GOSSYPII
}

By

ROBERT LAWRENCE STEPHENS

\begin{abstract}
A DISSERTATION PRESENTED TO THE GRADUATE COUNCIL OF THE UNIVERSITY OF FLORIDA

IN PARTIAL FULFILLMENT OF THE REQUIREMENTS FOR THE DEGREE OF DOCTOR OF PHILOSOPHY
\end{abstract}

UNIVERSITY OF FLORIDA

June, 1956 


\section{ACKNOWLEDCMENT}

The vrlter wishes to express his appreciation to Dr. T. W. Stearns, under whose direction this work was carried out; to the Fennessee Eastman Company for the Bodak Fellowship funds which permitted a more extensive study of the problem; to the Chemistry Department of the University of Florlda which provlded supplies and laboratory space; and to Dr. L. J. Wickerham of the Agrlcultural Research Service, United States Department of Agriculture, who supplied the culture of Ashbya gossypif. 
TABLE OF CONTEENTS

Page

ACKNOWLBDCMIENTS

LIST OF TABTES

LIST OF FIOURES

I. REVIIW OF THE LITERATURE

A. The Microblological Synthesis of Ribollavin

B. The Blosynthefice Relationships of Amino Acids 21

C. Chromatography

D. Riboflavin Assay

II. STATEMINT OF THE PROBLEM

III. BXPERTITANTAL

A. Apperatus

1. The Colorimeter

2. The Shaker

3. The pH Meter

4. The Muorometer 23

B. Generel Procedures

1. Keintenance of the Culture

2. Experimental Media 23

3. Inoculation and Incubation of Hedia 24

4. Measurement of Growth 25

C. Riboflavin Deteminations 26 
1. Preparation of the Sample for Riboflavin Deterrinatione

2. Fiuorometric Detemination of Piboflevin 26

D. Chromatography

1. Paper Sheets and Strips

2. Circular Chronatography

3. Column Chromatography

1. The Reletionship of Riboflavin Synthesis to Growth in a Peptone ledium

2. The Fractionation of Peptone on a Cellulose Colum 40

3. The Growth and Piboflavin Production of A. gossypil with Peptone Fractions as Mitrogen Sources

4. The Proximate Qualitative Chromatographic Analysis of the Anino Acids in the Peptone Fractions

5. The Iffect of Various Amino Acids Combinations on the Gronth and Piboflavin Formation of A. gossypi1

6. Further Studies on the Irfects of Amino Acide on the Growth and Blosynthesis of Riboflavin by A. gossypi1

7. The Effect of Serial Transfers of Cells of A. gossypil on Synthetic Media, on Growth and Riboriavin Pormation

8. The Growth and RSboflavin Formation of A. gossypif as Affected by Inocula Prepared from Cellis Sribjected to Different Numbers of Washings

9. The Iffect of Miscellaneous Nitrogen Sources on Growth and Ribollavin Pormation

10. The Treatment of Peptone with Permutit 
11. The Crowth and Riboflavin Synthesis on the Glutanic Ac1d-Arginine Nedium with Different Concentrations of Glycine

12. The Effect of Different Concentrations of Peptone on Growth and Riboflavin Formation in a GIutandc Acld-Argintne-1ycine Medium

13. The Effect of the Components of the Giutandc Ac1dArginine-Glycine Medium on the Synthesis of Ribollavin in a Peptone Medium

14. The Effect of a Cell. Extract of A. Eossyni1 on Growth and Ribollavin Formation

15. The Effect of Chronstographic Fractions of an A. gossupi1 Cell Ixtract on Ribollavin Formation

16. I Further Study of the Iffect of Cell. Extracts of A. gossvoli on Growth and Fiboflevin Forration

17. The Colorimetric Analyais of Riboliavin

18. The Effect of Giycine, I-Serine and DL-Threonine on Growth and Riboflavin Synthesis when Added to Different Synthetic Media

19. The Effect of Lmistidine $\mathrm{HCl}$ on Growth and Ribollavin Formation in Glutamic Acldarginine and Gutamic Acld-Arginine-Giycine Media

20. The Effect of Initial ph of the Mediun on Crowth and Iiboflavin Formation in the Glutanic AcidArginine Hedium and the Glutamlc AcidurginineG ycine-Histidine Medium

21. The Effect of Inddazole on Growth and Riboflavin Synthesis

22. The Effect of Different Concentrations of Giutanc scid or Aspartic Acid on Crowth, Riboflavin Formation and Histidine Inhibition in Synthetic Media.

23. Studies on Growth and Riboflavin Synthesis in the Qlutaric Acid-Arginfine-Histidine Kedium with Different Concentrations of Amino $\Lambda_{c i d s}$ 
24. Studies on Grovth and Riboflevin Synthesis in the Gutamic Acldarginine-fistidine liediun with Different Concentrations of Amino Aclds

25. A Study of Special Amino Acid Media

124

26. The Effect of L-Serine on RAboflavin Synthesis in Glutamic Acidarginine and Glutamic Acid-ArginineHistidine Media

27. The Effect of Different Concentrations of Asparagine on Growth and Riborlavin Formation in a Peptone Nedium

IV. SUMART AND CONCLUSIONS 
Table

Page

1 The Fuorescence of Standard Ribollavin Solutims

2 The $R_{f}$ Values of Amino Acids and Peptides in ButanolAcetic Acid-Water and Pyridine-Tertiary Amyl AlcoholWater Solvents on Circular Chromatograms

3 The Per Cent Transmittance, pH and Miboflavin Content of Cultures of A. gossyp11, and Dry Welghts of Their Extracted Ceilis, at Different Ages Grown in a Peptone Medium

4 The $n_{f}$ Values of Chromatographically Separated Fractions of Peptone

5 The Crowth and Pigmentation of Ashbya gossypil on Media Containing Peptone Practions as Nitrogen Sources

6 The $R_{f}$ Values of the Rings and Possible Amino Acids in the Hydrolyzates of Peptone Fractions

7 The Amino Acids Composition of Synthetic Media

The Effect of Amino Acid Combinations on Growth and Pigmentation by Aghbya gossyp11

9 The Effect of Added Amino Acids on the $C_{r o w t h}$ and Riboflavin Formation by Ashbye gossypli in a Histidine Base Medium

The Effect of Added Araino Acids on Growth and Riboflavin Synthesis in a L-Glutanic Acid-Histidine HCI Base Kedium

11 The Effect of Added Anino Acids on Growth and Riboflavin Synthesis in a Glutanic Acid-Histidine-Arginine Base Medium Serial Transfer of Cells on Crowth and Riboflavin Pormation 
13 The Effect of Serlal Transfer of Cells of Ashbya gossypis on Growth and PIbonavin Fornation on Peptone and Synthetic Media

14 The Effect of Serlal Transfer on the Growth and Pigmentation of $\mathbf{A}$. gossupli on the Clutanic Ac1d-Arginine Base Medium with Added Amino Acids

The Growth and Rboflavin Formation of A. gossypis on a Peptone Kedium Inoculated with BeriaI Transfer Cells

The Growth and Pigmentation on the Glutemic Acld-ArginineGIycine (CACIy) Medium Inoculated with Cells Washed a Different Number of Tines

The Growth and Riboflavin Formation on Media Containing Untreated and Permutit Treated Peptone

The $\mathrm{R}_{f}$ Values and Possible Amino Acids Present in a Chromatographed, Hydrolyzed Permutit Extracted Fraction of Peptone

The Growth and Ribollavin Synthesis of $A$. gossvpil in a Givtamic Acidarginine (GA) Media with Added Amounts of Gijcine

20 The Growth and Riboflavin Synthesis in a Glutanic AcidArginine-Glycine (GAGIy) Medium Containing Various Concentrations of Peptone

21 The Synthesis of Ribollavin in a Peptone Nediun Containing Components of the Olutemic Acldarginine-flycine (GAGly) Medium

22 The Synthesis of Riboflavin by A. gossypli in Glutanic AcidArglnine (GA) and Glutanic Acidarginine-Glycine (GAGIy) Medis Containing 0.1 Mililiters of Cell Extract

23 The Chromatographic Composition of an A. gossypil Cell Extract from a Butanol-Acetic Ac1d-Water Solvent Systen

24 The Effect of Orronatographic Cell Extract Fractions on Riboflavin Synthesis by A. gossypil in a Glutanic AcldArginine-Gljeine (GAGIy) Kedium

The Growth and Riboflavin Formation in a Glutamic AcldArginine-Glycine Medium with Added Cell Extracts and Acetone Dried Cella 
26 Absorbance Values for Known Riboflavin Solutions

27 The Determination of Riboflavin in Aliquots of an Bxtract of Cells and a Check of Recovery of Added Riboflavin

28 The Effect of Gircine, I-Serine or DL-Threonine on Crowth and Piborlavin Synthesis in Gutamic Acid-Arginine, (GA) Aspartic Acid-Arginine, (AA) and Asparagine-Arginine (AspA) Media

29 The Iffect of $\mathrm{H}_{1}$ stidine $\mathrm{HCl}$ on Growth and Riboflavin Formation in Giutanic Acld-Arginine (GA) and Giutamic Acid-Arginine-Glycine (GAGIJ) Media

The Effect of Histidine HCl on Growth and Riboflevin Formation in the Glutanic Acid-Arginine-Glycine (CAGly) Nedium

31 The Effect of Initial pil of Hedia on Growth and Riboflavin Formation in the Glutamic Acldarginine (GA) and Glutamic Acid-Arginine-GIyeine-HL stidine (GAGIyil) Vedia

32 A Comparison of the Effect of Imidazole with that of Histidine on Crowth and Riboflavin Synthesis in the GIutanic Acid-Arginine-Giyeine (GACIJ) Kedium

33 The Effect of Different Concentrations of L-Glutaric Acid and Laspartic Acid on Growth and Riborlavin Synthesis in Synthetic Media.

34 The Effect of Gycine on Growth and Riboflavin Formation During Four Days Incubation in Synthetic Medis with Gijeine Added at Different Times During Incubation

35 The Effect of Delayed Addition of Glycine on Growth and Ribollavin Forretion in Synthetic Niedia

36 The Growth and Riboflavin Formation in the Glutanic AcidArginine-llistidine (GAH) Mediwe with Different Concentrations of Different Amino lcids

37 The Results of Calculations to Determine the Riboflavin Symthesized per Milligram of Amino Acid Added to the GIutamic Acid-Arginine-filstioline ledium

38 The Amino Acids Added to the Basal in the Amino Actd $\mathrm{B}_{\text {ase Nedium }}$ 
39 The Growth and Ribollavin Synthests on a Special Amino Acid Hedium with Different Concentrations of Principal Nitrogen Sources

Lo The Effect of Serine on Ribonavin Formation in Glutenic Acid-Arginine (GA) and Glutamic Acid-Arginine-Histidine (GAH) Media with Different Concentrations of Glutamic Acid

41 The Bffect of Different Concentrations of Asparagine on Growth and Riborlavin Formation in a Peptone Vedium 
I.IST OF FIGURFS

Pigure

Page

1 The Blosynthetic Relationships of Amino $A_{c i d s}$

2 A Standard Ribollavin Curve

30

3 The Relationship of Growth, pH and Riboflavin Content of Cultures of A. gossypil Grown in a Peptone Medium and the Dry Weights of Their Ixtracted Cells

4 A Standard Curve for the Colorimetric Analysis of Riboflavin 


\section{REVIEW OF THE LITERATUFE}

A. The Microblological Synthesis of Riborlavin

Riboflavin, one of the B complex ritemins, was first discovered by Goldberger and Iillie (34) while studying the nature of pellagra. They reported the exdstance of a heat stable substance which prevented certein deficiency aymtams in rats which were on speciel diets. Xuhn, et al., (49) 1solated a yellow-green fluorescent substance from egg white and demonstrated that it was similar to the factor reported by Goldberger and Lillie. Flinger and Koschara (26) reported the isolation of a similar substance from whey, Itver, kidney, muscle, yeast and certain plant materials. These 1solated materials were named ovoflavin, lactorlavin, heptoflavin, etc., depending on the source from which they had been isolated. When It becane known that they contalned the same active substance, the varlous names were discarded and the nane, riboflavin, was adopted. Karrer, Schopp and Benz (4h) described the first chemical method for the synthesis of riboflavin which has the following structure:

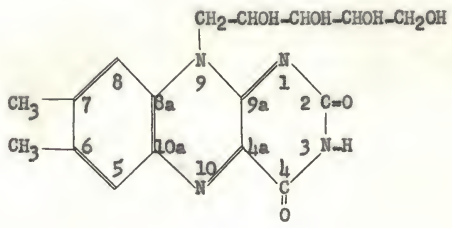


Von Erler, et al., (108) established that synthetic ribollavin and the natural substance were Identical.

Although the cheanical synthesis of ribollavin has been well estabIished, the methods by which organisms synthesize riboflavin have not been -lucidated up to the present time. Riboflavin has been reported to be synthesized in appreciable anounts by several microorganiams, namely, Clostridium acetobutylicum (117), Candida guiliermondia (90), Candida Marerf (99), Mycobacterium smegmatis (53), Aspergillus Mlavus (70), Fusarium species (62), Saccharomyces cerevisiae (33), Eremothecium ashbyli1 and Ashbre gossypi1 (37). The closely related Hitcroorganisme, Eremothecium ashbyi1 (․ ashbyi1) and Ashbye gossyp11 (․ gossypi1), are used in the commercial microblological synthesis of riboflavin due to their capacity to produce large amounts of the vitanin. For this reason, the conditions for microbiological synthesis of ribollavin have been studied more widely In these organtame than in other known producers of the compound. The microorganisms, E. ashbyi1 and A. gossypi1, are plant pathogens, having been 1solated from the infected boll of the cotton plant. Guillermond, Fontaine and Raffy (37), in 1935, reported that the organism, E. ashbyli, produced a yellow-orange fluorescent pigment when eultured on Sabouraud's liedium at $25^{\circ} \mathrm{C}$. They found that 1 . gossypit produced only small amounts of the pigment when cultured under the same conditions. Rafy and Fontaine (76) produced large amounts of the flavin pigment by growing E. Eshbyit on Sabouraud's Agar Mediun and Raffy (75) showed by rat experiments that the pigment had vitamin properties similar to riboflavin. Mirimanoff and Raffy (59) demonstrated that, microchemically, physlologically, spectrographically and fluorometrically, the flavin pigment was 
identical with riboflavin.

In 1930, Farries and Bell (27) stated that 1. gossypif would not grow on artificial media containing $\mathrm{KNO}_{3}$ and amonium salts unless supplenental growth factors were present. However, hydrolyzed natural protelnaceous material would serve as a good nitrogen source for growth. Buston and Pramanik (12) established that the factor necessary for growth was a complex. One component was Inositol and the other was a substance which was similar to a then little known factor called biotin. Kogl and Fries (47) and Fries (28) showed that three factors, biotin, thiamine and Inositol, were necessary for the growth of A. gossypif. Buston, Kasinathan and Wylie (II) reported that Inorganic and organic ammonium salts would not give satisfactory growth when added to a medium of natural lentils extract, mineral solts and Inositol. However, when $\beta$-alanine or L-asparagine was used, moderate growth was obtained.

The first systematic study of riboflavin production by $\underline{E}$. ashbyif was made by Schopfer (89) who used a basal I1quid medium containing, 1 per cent glucose, 0.1 per cent glycine or asparagine, 0.05 per cent $\mathrm{MgSO}_{4} \cdot 7 \mathrm{H}_{2} \mathrm{O}$ and 0.15 per cent $\mathrm{KH}_{2} \mathrm{PO}_{4}$, to test the effect on riboflevin synthesis when different natural extracts were added to the basal medium. Liver extract, at a concentration of 3 per cent, produced a marked stimulation of riboflavin synthesis in the basal medium. There was a considerable variation In the amount of mboflavin produced when peptones from varlous sources were tested. Norite treatment of peptone rendered it inactive for the synthesis of the vitamin. Biotin was reported to be essential for growth and riboflevin synthesis with thiamine and inositol acting as complenentary growth factors. 
Renaud and Lachaux $(81,82)$, in experiments with $\mathrm{E}$. ashbyli grown on a liquid medium of peptone, glucose and $\mathrm{NaCl}$, reported that the depth of the medium was a factor Influencing yields of Mboflevin, highest ylelds being obtained when the depth was less than 1 centimeter. They obtained highest yields on the peptone-glucose medium when 1.5 - 3.0 per cent glucose and 1.2 per cent peptone vere used. The addition of 0.1 per cent $\mathrm{NH}_{4} \mathrm{H}_{2} \mathrm{PQ}_{4}$ was benifleial. Schopfer and Cuslloud (91) reported that leucine or arginine, alone or in combination, supported the growth of E. ashbyli in a medium to which blotin, thiamine and inositol had been added.

Moore, de Becze and Schraffenberger (60) studied the synthesis of Mboflavin by E. ashbyii using the shake nask method of growth. The optimum temperature was found to be between $26-30^{\circ} \mathrm{C}$. with an optimnm pli of $5.5-6.5$. The pll was reported to increase to the alkaline side in the later stages of growth. Refrigeration of the culture at $4^{\circ} \mathrm{C}$. for more than 7 days reduced the ability to produce riboflavin. Lyophilization destroyed the vitemin synthesizing ability completely.

Mudert (86), using E. ashbyil, reported that ribonlavin could be synthesized on a carbohydrate free mutrient medium containing a metabolizable lipid, such as corn oil, egg albumin and mineral salts, ss long as sufficient air was supplied to the culture. Deseive (2I) observed that 0.001 per cent cystine reduced the growth of $\underline{\mathrm{E}}$. ashby11 and inhibited the riboflavin formation.

Chin (13) studied the growth and riboflavin formation of $\underline{\mathrm{E}}$. ashbyli In a medium of 1 per cent glucose, 0.2 per cent $\mathrm{KH}_{2} \mathrm{PO}_{4}, 0.1$ per cent $\mathrm{MgSO}_{4}$, 0.1 per cent $\mathrm{NaCl}, 0.1$ per cent agar, 5.0 per cent rice germ extract and 5.0 per cent of a suitable nitrogen source. Peptone was the best nitrogen 
source, followed by glutamine, asparagine, alanine and $\left(\mathrm{NH}_{4}\right)_{2} \mathrm{SO}_{4}$ in decreasing order of suitability as a nitrogen source. Tryptophan, tyrosine, cystine, cysteine, htstidine and urea were not satisfactory. Glucose, sucrose and glycerol were good carbohydrate sources but glycol, zylose and mannitol could not be used.

Phelps (63) grew E. ashbyil on a medium with solubilised casein as the nitrogen source. He reported that $0.25-2.5$ per cent fatty acid glycerldes increased the synthesis of riboflavin with the greatest stimlation being shown by buttex fat.

In 1946, Wickerham, Fleckinger and Johnston (113) reported that a yellow-orange varient strain of $\mathbf{A}$. gossyp11 resulted from contimal transfers of the original light yellow strain. This new strain was able to procuce appreciable quantities of ribollavin when grown under proper conditions. When grown in a modium of 0.3 per cent yeast extract, 0.5 per cent peptone and 2.0 per cent glucose at pH $6.8-7.0$, under aerated culture conditions and at $28^{\circ} \mathrm{C}$. , abundant anounts of riboflevin vere produced. They reported that sucrose and maltose but not lactose could be used as a substitute for glucose.

Tanner, Vojnovich and Van Lanen (100) made an extensive studj of the conditions for growth and riborlavin synthesis by the organisan, $\mathbb{A}$. gossypit. The organism grew well over a wide temperature renge but highest Jields of riboflavin were obtalned when the culture was Incubated at 26 $28^{\circ} \mathrm{C}$. Temperatures higher than $28^{\circ} \mathrm{C}$. decreased the riboflavin aynthesis sharply, whereas tenperatures below $26^{\circ} \mathrm{C}$. caused a lesser decrease. The best initial pH range was found to be between 6.0 - 7.0. Glucose at a concentration of $0.25-3.0$ per cent served as an adequate carbohydrate 
source. Sucrose and maltose in relatively pure form could replece glucose but xylose and arabinose were not metabolized. They found that 0.5 per cent corn steep Ifquor with 0.5 per cent peptone, as nitrogen sources, gave very high glelds of ribollavin. The fermentation was reported to be comprised of two distinct phases. In the fIrot phase, which occurred during the Pirst $2 \mathrm{~h}-36$ hours, glvcose was assimilated, the medium becane more acid and very little rlboflavin was formed. The second phase occurred after glucose consuruption was substentially complete and was characterized by an increase in the pll of the medium and a rapid production of riboflavin.

Pridhan (71) found that riboflavin synthesis by $\Lambda$. gossypil was increased by the addition of $1-2$ per cent of a fermentable sugar to the medium after the fermentation had progressed for 24 - 72 hours, usually during the period of $\mathrm{pHI}$ increase between $\mathrm{pH} 5.3$ and 6.4 .

Nost of the early work on riborlevin synthesis by $\underline{\mathbb{E}}$. aghbyil and A. gossypii was mainly designed to bring about a greater commercial production of the vitamin under more economical conditions. It was not until about 1950 that any interest was directed toward how these microorganiams produced riboflavin and what chemical components were involved in this synthesis. Dulaney and Orutter (2L) studied the nutritional requirements of E. ashbyl1 grown on a mediun of glucose, hydrolyzed carein, inositol and mineral salts. They found that inositol was necessary for growth and riboflavin production and that low levels of glutamine, pantothenic acid, Vitamin $B_{12}$, nicotinic acid, pyridoxdne, choline, p-aminobenzole actd and follc acld had no effect when added singly or together. L-prolline, DLglutanic ac1d and L-arginine with inositol gave growth and riboflavin 
formation.

Minoura (56) reported that ashed peptone had no growth promoting not riboflavin producing effect on $\underline{\mathbb{B}}$. ashbyli. Hydrochloric acid hydrolyzed peptone was more effective in promoting growth and ribollavin synthesis that untreated peptone. Asparagine and arginine promoted the growth of the organism but no riboflavin was produced.

Pridham and Raper (72) gave an extensive morphological and cytological description of A. gossypi1. They described the growth eycle of the organism from the vegetative stage, through the sporulation stage and to the spore germination stage. Photomicrographs illustrating the different grovth phases included the "bulb forms" which accompany rlbonavin synthesis. In another report, Pridham and Raper (73) also subJected 1. gossypif cultures to ultra violet light, x-ray radiations and chemlcal mutagenic agents in an attempt to get higher riboflavln producing strains. In general, the trend of mutation effect was the formation of degenerate atrains which produced less riboflavin. The addition of 0.1 per cent sodium dithionite to the stock medium enhanced pigment formation and tended to maintain the organisms at a high flavinogenic state.

Iaw (118) reported that mathionine was important in the growth of E. ashbyis. Histidine was thought to be related to riborlavin synthesis either by direct incorporation Into the vitanin molecule or by an indirect effect on the synthesizing system. The medium for these studies was completely defined being composed of glucose, asparagine, histidine, 1nositol, biotin, thiamine and mineral salts.

Vaciaren (50) studied the effect of various purines and pyrimidines on the growth and mboplavin synthesis of $\underline{E}$. ashbyli in a variation of 
Yaw's medium. The purines, adenine, xanthine and guanine increased riboflavin synthesis without increasing the growth of the organism. The pyrimidines, uracil and thymine, did not effect the growth of the organiam but uracil inhibited the synthesis of riboflavin. Macharen postulated that a "purine pathway" may exist in the process of riboflavin biosynthesis.

Dikanshaya $(22,23)$ observed that more active growth of $\underline{\mathrm{I}}$. ashbyli proctuced less riboflavin. Folic acid and p-minobenzolc acid were needed for growth and biotin and Inositol were needed for riboflavin synthesis. A low vitamin content of the medium along with sparse mycelial growth contributed to favorable conditions for riboflavin formation. Strains of E. ashbydi most effective in riboflavin synthesis had weaker cytochrome systems but more active dehydrogenase and proteolytic enzyme systems than Low mboflavin producing strains.

Kinoura $(57,58)$ reported that arginine ves most effective in promoting riboflavin synthesis in E. ashbyli. Other amino acids, in decreasing order of effectiveness were, aspartic acid, glutanic acid, esparagine, proline, lysine, methionine, phenylalanine, leucine and tyrosine. Serine and norleucine were inferior to $\left(\mathrm{NH}_{4}\right)_{2} \mathrm{SO}_{4}$. Asparagine was most effective in increasing growth. The addition of $0.01-0.1$ milligrans of $r$-benzene hexachloride per 100 milliliters of medium increased the synthesis of riboflavin; however, concentrations greater than 0.1 willigram were inhibitory to the vitamin synthesis.

Van Lenen, $S_{m i l e y}$ and Stone (105) devised an anino acid medium for the growth and riboflavin synthesis of A. gossypif. Olycine, alanine, threonine and proline added to a sucrose, Vitamin, mineral salts medium 
gave a noticeable yield of riboflavin. Dicarboxylic acids and related compounds were reported to interfere with riboflavin synthesis.

Coodvin and Pendlington (35), using a 0.005 per cent peptone basal medium, reported that I-serine, L-threonine or I-tyrosine stimulated riboflavin synthesis in E. ashbyli. In-glutamic acld, Lmaspartic actd and L-asparagine stimulated both growth and vitamin synthesis, whereas L-cystine inhibited both. The other amino acids and $\left(\mathrm{NH}_{4}\right)_{2} \mathrm{SO}_{4}$ were without effect. Xanthine, adenine and adenosine increased mbohavin synthesis but pyrimidines had no effect. Alloxan inhibited growth and riboflavin synthesis. Klungsoyx $(45,46)$ obtained riboflavin synthesis by cells of $\underline{E}$. ashbyil suspended in a buffer composed of $\mathrm{NaCl}$, $\mathrm{HCl}, \mathrm{NigSO}_{4} \cdot 7 \mathrm{H}_{2} \mathrm{O}, \mathrm{Na}_{2} \mathrm{HPO} / 4$ adjusted to pil 6.9. He proposed that the riboflavin was synthesized in preformed cells and that growth and riboflavin synthesis may be regarded as independent processes. When acetic acid-1-CI/ was added to the synthesizing cells, less than 0.01 per cent of the added Cll activity was recovered in the riboflavin and this was found to be in the carbon-2 atom of the ring portion of the molecule. The activity from added Cl/-formate was also found to be in the carbon-2 atom of the ring.

MeNutt $(51,52)$ continued the work of Macharen on E. eshbyli, using uniformly labeled adentne. He reported that the adenine was principolly incorporated into the 6,7-dimethylisoalloxazine portion of the riboflavin molecule, further substantiating the posiculated "purine pathwas" of riborlavin synthesis. Naturally occurring purine macleosides and mucleotides were no more effective than the parent purines in increasing riboflavin synthesis.

Brown, Goodwin and Pendlington (10) reported that pyruvate was the 
only non-nitrogen compound related to serine and threonine which gave an increase in riboflavin formation with $\underline{E}$. ashbvil. Aminopterin, at a concentration of 2 micrograns per 100 millsuter inhibited the growth of the organism but stimulated navogenisis.

Plaut $(66,67,68)$ reported on the location of tagged atoms in the riboflavin molecule when cll-formate, cll-bicarbonate, acetic acids1-Cl4 and 2-Cl4, glycines-1-Cll and 2-Cl4, and totel1y labeled glucose were added to a growing culture of A. Bossypli In a medium of corn steep Hequor, peptone and glucose. He found that the Cll-formate activity was concentrated in the carbon-2 atom of the mbonavin, wherees the Cll-bicarbonate activity vas in the carbon- 4 atom of the molecule. Acetic acid1-Cll produced activity in the carbon-4 atom but to a lesser degree than cll-bicarbonate. The acetic acid-2-cll activity was in the methyl groups, carbons $-5,6,7,8,8 \mathrm{a}$ and $10 \mathrm{a}$ and in the ribltyl side chain of the molecule. A sinilar distribution of activity was shown with uniformily labeled glucose. The activity of the labeled glycines was located predominantiy in carbons- $4 a$ and $9 a$ of the ring portion of the ribollavin molecule. The addition of glucose-1-Cll and glucose-6-Cll resulted in the activity being primarily located in the methyl groups and carbons- 5 and 8 . Plaut expressed the possibility of a two carbon fragment being involved in the synthesis of the cyclic carbon ring of the ribollavin molecule. Plaut and Broberg (69) have reported further studies on the incorporation of $\mathrm{Cl}_{4}$ acetate and glucose into the ribityl side choin of riborlavin. The abundance of research on the problem of riboflavin synthesis by microorganisms is shown by the number of reports in the literature, however, the question of the nature of the pathway of synthesis remains 
unanswered. Further research on the growth and metabolism of these riboflavin synthesizing organisms will no doubt eventually provide the answer to this question.

B. The Blosynthetic Relationships of Amino Acids

Amine acids are often referred to as the "bullding blocks" of protein, but they are also essential in the blosynthesis of other inportant nitrogen containing biological compounds. The structure of Flboflavin indicates that there are four nitrogen atoms per molecule and, therefore, anino acids might be expected to play a key role in the biosynthesis of the molecule. The relationship of amino acids to riboflavin blosynthesis is emphasized by the fact that formation of the vitanin by microorganisuns is dependent on a sudtable organic nitrogen source as shown by many references in the preceeding section. The review of the biosynthetic relationahips of anino ac1ds in this section will be of general nature and, for the most part, restricted to processes in microorganisms. A more comprehensive survey of the subject may be obtalned from recent reviews $(19,54)$. One of the irportant amino acids involved in transamination reactions is alanine which is present in a wide variety of natural proteinaceous meterials. It is related to pyruvic acid through the transamination reaction sequence, glutamate + pyruvate $\longleftrightarrow \alpha-d k e t o g l u t a r a t e$ + $\alpha$-alanine, which is reversible (36). Thls reaction serves as the mechanism for the nicroblological synthesis and degradation of $\alpha$-alanine. The courpound, $\beta$-alanine, is one of the less connon amino acids but it 18 important as a part of the vitamin, pantothenic acid which makes up part of coenzyme A. Gale (31) reported that $\beta$ malanine could be formed 
by the decarboxylation of aspartic acid. It has been shown by Roberts, et al., (83) that $\beta$-elanine was associated with transamination in Aspergillus fumigatus; however, the reaction mechaniam has not been estab1ished. In rat feeding experiments with 1sotople compounds, Phil and Fritsson (65) sound that $\beta$-alanine was rapldly oxidized and part of the carbon chein converted to acetic acid. They were of the opinion that oxldation took place after the amino acid had been deaninated and decarboxylated.

Aspartic acid, like $\alpha$-alanine, is important in nitrogen transfer reactions involving transanination. It is synthesized in many microorganims by the amination of fumaric acld which is a reveralble reaction catalyzed by the enzyme aspartase (30). It has also been reported to be formed by a transamination reaction involving oxaloacetic acld ( 48 ). Abelson and Vogel (3) stated that aspartic acid wes the precursor for the amino acids, homoserine, methionine, threonine and isoleucine, in Torulopsis ut111s and Neurospore crassa. Aspartic acid has been reported to be associated with the blosynthesis of Coenzyme A (31), purines (110) and pyrinldines (77). Asparagine is formed by the amidation of aspartic acid; however, the reaction mechanism is not known. Black and Qray (7) reported that $\beta$-aspartyl phosphate may be a precursor of ssparagine. In a rat liver preparation, Neister and Fraser (55) found that asparagine could be formed by the transanination of $\alpha$-ketosuccinanic acld with glutamine which was the most active anino group donor. Asparagine is important as a nitrogen source for many microorganiams.

Another amino acid, glutaulc acid, occuples an important position in the nitrogen metabolism of microorganisms and animals. It is primarily 
formed through the transamination of $\alpha$-ketoglutaric acid (32) and the reaction of $\alpha$-ketogluterate with anmonia catalyzed by the engyme glutanic dehydrogenase. Giutanic acid can aløo result from the degradation of proline, arginine or histidine. Shemin and flussel (92) reported the blosynthesis of glutamate by the reaction of glycine and succinate via $\delta$ aminolevilenic actd. Abelson (1), using 1sotope inhibition analysis, clasmed that glutaric acid was the precursor of proline, ornithine, citrulline and arginine. Glutamine, the anide of glutanic acid, is synthesized by the combination of glutamic acid and amonia in the presence of $\operatorname{ATP}(42,112)$.

Arginine is synthesized from glutanic acid, via ornithine and citrulline, in ‥ coll and wany other microorganirms. Anderson-Kotto, et al.., (5) established that In ․․ coll II-acetylglutamic acid was one of the intermediates in the synthesis of ornithine from glutamate. Srb and Horowltz (95) reported the formation of citrulline from ornithine in Neurospora, the mechanism not being known. Citrulline and aspartic scid form arginine via the intermediate, arginino-succinate $(79,78)$. Vogel, et ㄹ‥, (106) reported that the activity of labeled N-acetylglutaric ac1d was heavily concentrated in the arginine synthesized by $\mathrm{I}$. colli, verifying the glutamate to arginine sequence.

Vogel and Davis (107) have reported that proline, an indno acid, was formed from glutaric acid Va glutanic $r$-semialdehyde and $\Delta^{\prime}$-pyrrolino5-carboxylic acid in two mutant strains of $\underline{E}$. cols.

The blosynthesis of lysine is belleved to follow different pathways In bacterla and fung1. Davis (17) reported that in $\underline{E}$. coli $\alpha, \alpha$-diaminopimelic acid is an intermediate in the synthesis of lysine from aspartic 
ac1d. In Neurospora, Windsor (114) showed that $\alpha$-aminoadipic acid could be converted to Iysine. Strassman and Weinhouse (97) established that the alpha carboxyl carbon of lysine was derived from acetate as shown by the use of labeled acetate as the sole carbon source for a yeast and Neurospora. They proposed that carbons- 3 and 6 resembled the succinvl moiety of $\alpha$-ketoglutarate and that acetate probably condensed with succingl-Coenzyme $A$ in the Initial step of lysine biosyntheris. Rothstein and Millar (85), using 1 ysine $-6-C^{14}$ proposed that lysine degraded to $\alpha$-ketoglutarlc acld and acetate $\mathrm{Vla} \alpha$-aninoadipic acld.

The blosynthesis of histldine is not too clearly understood at the present time. Purine bases have been reported to be related to histidine biosynthesis in lactic acid bacteria (9). Fries (29) suggested that asparagine may function as a nitrogen donor in some step of histidine blosynthesis since either histidine or asparagine were required by a mutant of the mold, Ophiostoma. In accumulation studies with Neurospors, Haas, et 2l., (38) have proposed a path of synthesis via Imidazole glyeerol phosphate, inidazole acetol phosphate, histidinol phosphate, histidinol and histidine. In yeasts grown with labeled acetate, the carboxyl groug of histidine was reported to be derived from the methyl group of acetate (25). Ames and Mitchell (4) have suggested that the five carbon chain of histidine might cone Irom pentose-5-phosphate. Using 1sotope distribution analyais, Wolf (115) showed that hlatidine could be degraded to glutanic acld through some unknown path of reactions.

Tryptophan, phenylalanine and tyrosine are biosynthetically related through the common precursor, shikimic acid (16). Davis (18) reported that phenylalanine was synthesized from shikimic acid via prephenic acid and 
phenylpyruvic acid. Prephenic acld has also been shown to be a precursor for tyrosine biosynthesis in a tyrosine requiring mutent of Neurospore (20). Srinivasan, et al.., (96), in experiments with labeled glucose, have suggested that the side chatns of phenylalanine and tyrosine may arise from a glycolysis product. In tryptophen biosynthesis, shikimic acid was converted to anthrenilic acld (102). Rafelson, et 르., (74) showed that acetate was added to anthrantilic acld to give indole. Tatum and Shemin (101) reported that serine combined with indole to form tryptophan in the presence of the enzyme, tryptophen desmolase.

Serine and glycine are known to be related in their metabolisms but there is some question whether serine or glyeine is formed first. Ehrensvard, et al., (25) reported that the pathway, pyruvate, serine to glycine, probably exdsted in Torulopsis utilis, since ovidence indicated that the same isotoplc distribution in alanine, serine and glycine occurred when labeled acetate was used as the carbon source. Abelson (1) also reported the gynthesis of glycine from serine in E. coll using labeled serine and glycine in the presence of glucose. Wang, et al., (III) obtained evidence that serine was synthesized from glycine in baker's yeast when pyruvate-2 $-C 14$ was the sole carbon source. Low (43) has presented evidence that the carboxyl group of glycine is incorporated into the pentoses of ribonucleic acids. Clycine has also been shown to be incorporated into purine bases (98).

Cystine and cysteine are two oulfux containing amino acids which are important in metabolism. Abelson (1) reported that inorganic sulfur and serine combined to form cysteine which was further converted to cystine in E. colf. Plerpoint and liughes $(64)$ have pointed out that in 
Lactobaciliug arabinosus Coenzyme A fornation from pantothenic acid would proceed only if cystine was present in the mediun.

Ehrensvard, et al., (25) proposed that throonine synthesis origlnated with aspartic acid in Torulopsis utilis and E. colf since the isotope distribution with labeled acetate was the same in aspartic acid and threonine. Woods, et al., (116) have reported that threonine can spare aspartic acid requirements in certain lactic acid bacteria. The work of Abelson, et 2l., (2) has shown that homoserine can serve as a precursor for threonine. Black and Wright $(8)$ have suggested that $\beta$-aspertyl phosphate and aspartic acid $\beta$-semialdehyde may be intermediates between aspartic acid and homoserine in the pathway of threonine synthesis. The formation of homoserine fram $\beta$-aspartyl phosphate has been shown to be inhibited by glutamic acid in Leuconostoc dextranicum (80).

The biosynthesis of valine has been shown to proceed from pyruvic acid via $\alpha$-ketoisovaleric acid $(1,3)$. Abelson (1) has suggested that leucine may be derived from pyruvic acid via $\alpha$-ketolsovaleric acid and $\alpha$-ketoisocaproic acid. He proposed that $\alpha$-ketolsovalerate may contribute carbons- 3 and 6 to combine with acetate in the formation of $\alpha$-ketolsocaproic acid. Ehrensvard, et 르., (25) and Cutinelli, et al., (15) have established that the $\alpha$-carbon atom and carboxyl group of leucine are derived directly from acetate in yeasts and bacteria. Abelson and Vogel (3) reported that isoleucine is formed from threonine vis the intermediates $\alpha$-ketobutyric acid and $\alpha$-keto- $\beta$-methylvaleric actd.

Methionine is a sulfur containing anino acid which is importent in tranomethylation reactions. Homoserine and cysteine combine to form cystathionine which is converted to methionine $(40,41)$. Cystine can spere but 
not replace methionine as a growth factor $(84)$.

The relationships of anino acids are sumarized in Figure 1.

\section{Chrounatography}

Chromatography 18 an important technique which is used in the separation and analjsis of biological materials. The flrst application of chromatography 1s usually attributed to Tswett (103) who separated green leaf extract into different fractions by means of a column of powdered calcium carbonate. The introduction of paper-partition chromatography by Consden, Gordon and Martin $\left(U_{4}\right)$ In 1944 was one of the most important recent advances in chromatography. Paper chromatography is probably one of the most widely used methods in the biological research of today.

There have been meny variations of the original technique which resolved mixtures on paper strips or sheets by means of various solvents. Rutter $(87,88)$ introduced a method which he called circular chromatography, which allowed a separation of a mixture by the movement of the solvent system through a small wick cut from the center of a filter paper disk, thus giving a series of rings making wp the components of the mixture. The method gives the advantage of rapid separation of mixtures but the resolution is not very clear cut.

The solvent system is Important for the proper separation of components in paper chromatography. One of the flrst solvents was couposed of water saturated phenol solution ( $\left.\mathrm{I}_{4}\right)$. Slotta and Primosigh (93) Introduced the solvent system, n-butanol-acetic acid-water, which is widely used for the separation of many groups of compounds. The components of the solvent were mixed in the ratio of $4: 1: 5$, respectively, by volume and 
THE BIOSWTHETIC RELATIONSHIPS OF AMTMO ACIDS

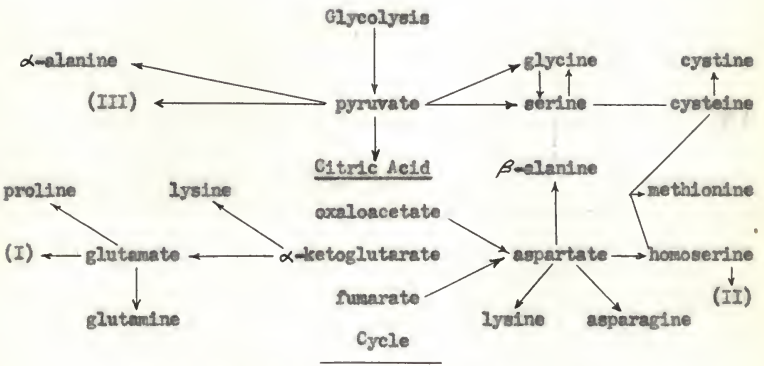

(I) ornt thine $\longrightarrow$ eltruliline $\longrightarrow$ arginine

(II) threonine $\longrightarrow$ 1soleveine

(III)

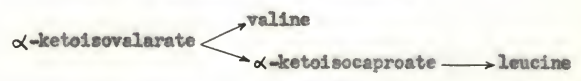

\section{HISTININE}

$? \longrightarrow$ histidinol phosphate $\longrightarrow$ histidinol $\longrightarrow$ histidine

\section{ARONATIC AMINO ACIDS}

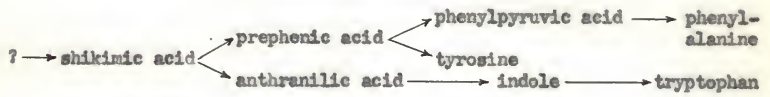


the top layer used as the solvent. Another useful solvent is composed of pyridine, tertiary anyl aleohol and water in the ratio of $3.5: 3.5: 3$ by volume (61). A comprehensive survey of the voluminous literature on chromatography is beyond the scope of this review. The references presented include only those considered to be pertinent to the problem.

\section{Ribonavin Agag}

After riboflavin was established as a growth factor, it was necessary to provide a means of analyzing for the vitamin. Von Filer and Malmberg (109) introduced the biological assay method which was designed to measure ribollavin by comparing changes in growth rates of test animals, usually rats, treated with the unknown sample and animals given standard amounts of raboflavin.

Snell and Strong (94) developed the microbiological method of riboflavin assay which is extensively used today. It is based on the growth response to riboliavin by the microorgantsm, Lactobacillus cesel, which produces lactic acid in proportion to the amount of the vitamin present under certain conditions. The lactic acid procuced with the unknown is titrated and conpared with that produced with standard anounts of the pure riboflavin. The assay is very reliable but it must be carried out under carefully controlled conditions and requires the preparation of apecial culture media.

The fluorometric analysis of ribollavin was introduced by $\mathrm{Van}$ Eckelen and Dmerie (104). Under the influence of ultraviolet light, riboflevin exhibits a characteristic Iluorescence which is proportional in Intensity to the amount of mboflavin in dilute solutions. Hodson and 
Norrls (39) modified the method by introchucing the use of sodiun dithionite to reduce the riboflavin to the colorless form without effecting the other fluorescing substances present, thus increasing the accuracy of the procedure. The Association of Vitamin Chemists (6) has described a standard fuorometric procedure, including extraction techniques and methods of perforning the assay.

Tanner, et al., (100) extracted the riboflavin from A. gossypif cells by autoclaving them for 30 minutes at 15 pounds stean pressure in a $0.123 \mathrm{M}$ sodiun acetate buffer at $\mathrm{pH} 4.7$.

Yaw (118) used a colorimetric assay method to determine riborlavin extracted from $\underline{E}$. ashbyli cells. The nethod, using a Klett-Srumerson colorimeter, was reported to agree within plus or mima 5 per cent of the microbiological method; however, there were no details given for the procedure, 


\section{STA TEMENT OF THE PROBLFM}

Although the conditions for the comnercial synthesis of riboflavin are well established, the mechanlams by which microorganians synthesize it have not been fully elucidated. This study of the metabolism of riboflavin by Ashbye gossypii was undertaken in an effort to gain more facts pertaining to the mechanim of riboflevin synthesis in microorganisms and, thereby, bring about a more complete understanding of the pathway and intermediates participating in the synthesis. 


\section{EXPERTMEATAL}

\section{A. Apparatus}

1. The colorimeter. An Evelyn Photoelectric Colorimeter, manufactured by the Pabicon Company of Philadelphia, Pennsylvania, was the instrument used in turbidimetric measurements of growth and colorinetric determinations of riborlavin. The instrument is a single-photocell, direct reading, photoelectric photometer equipped with light filters and a light bean galvanometer.

2. The shaker. A platform reciprocating shaker, constructed in the Chemistry Depertment shop at the University of Florida, was used to maintain an efficient seration of the cultures during incubation in liquild media. The ahaking platform accomodated flfty $250 \mathrm{ml}$. narrow mouth Irlemneyer Rasks which were held in place by a renovable plywood top containing 50 two and one-half inch holes to separate the flasks. A second layer of fifty flasks could be added by attaching a special tray to the main shaking platform. The shaleing rate could be adjusted by using different size pulleys; however, the size pulley used provided a shaking rate of 90 three 1nch strokes per minute. The shaker was housed in a constant temperature room at $28^{\circ} \mathrm{C}$.

3. The pH meter. A Beckman Model H-2, Iine operated, glass electrode $\mathrm{pH}$ meter with attached constant voltage transformer was used for all pH measurements. The pH meter was standardized before use against a pH 7.0 buffer prepared from a Becknan concentrated liquid buffer. The 
Instrument was allowed to warm up for at least a half an hour before atandardisation.

4. The fluorometer. A Colenan Universal Spectrophotometer, Model $\mathrm{I}_{\mathrm{h}}$, was used for the fluorometric determinations of riboflavin. The instrument was adapted to fluorometric analysis with aniversal Ultravlolet IIluminator and set of filters, UV-2 and PC-2, specific for riboflavin analysis. Round, fluorometer microcuvettes which held $10 \mathrm{ml}$. of sample were used with a special microfluorometric cuvette jig.

\section{B. General Procedures}

1. Maintenance of the culture. The culture of $\underline{A}$. gossypi1, strain NhR I-1056, obtained from the Northern Reglonal Research Laboratory of the Department of Agriculture in Peoria, Illinois, was meintained on stock agar slants which were prepared from a medium conteining 2.0 per cent glucose, 1.0 per cent Difco-peptone, 0.5 per cent Difcojeast extract and 1.8 per cent Difco-agar. The medium was sterillzed by autoclaving at 15 pounds stean pressure for 30 minutes and slanted. Transfers were made to new slants every 48 hours in order to naintain an actively pigmenting culture. Every two or three weeks, a 4-day-old, plgmenting culture was placed in the refrigerator at $8-10^{\circ} \mathrm{C}$. so that a pigmenting strain would be avallable in case of contamination or loss of the ability to produce constant pigmentation. The cultures were incubated in a constant temperature room at $28^{\circ} \mathrm{C}$.

2. Experimental modia. Liquid media were prepared by adding different nitrogen sources at different concentrations to a general basal 
medium containing $2.0 \mathrm{~g}$. glucose, $0.1 \mathrm{~g} . \mathrm{KH}_{2} \mathrm{PO}_{4}, 0.1 \mathrm{~g} . \mathrm{K}_{2} \mathrm{HPO} / 4,0.1 \mathrm{~g}$. $\mathrm{NaCl}_{3} 0.05 \mathrm{~g} . \mathrm{MgSO}_{4} \cdot 7 \mathrm{H}_{2} \mathrm{O}, 3.0 \mathrm{mg}$. Inositol, $0.1 \mathrm{mg}$. thiamine- $\mathrm{HCl}$ and $2.0 \mathrm{ug}$ biotin in $100 \mathrm{ml}$. of distilled water. In the early experiments, $0.05 \mathrm{~g}$. $\mathrm{NaCl}$ was used in place of the $0.1 \mathrm{~g}$. NaCl as shown in the general basal medium. All media were adjusted to $\mathrm{pH} 6.5-6.6$ with 0.1 1.0 molar solutions of either NlaOH or KOH unless otherwise specified. In each shaker flask for inoculation, $20 \mathrm{ml}$. of liquid medium was placed. When solid media were used in an experiment, $1.8 \mathrm{~g}$. of Difcomagar was added to each $100 \mathrm{ml}$. of liquid media. Such solid medie were dispensed in 10 to $12 \mathrm{ml}$. volumes per tube and slented after autoclaving. A1I media were sterlilized by autoclaving at 15 pounds steam pressure for 17 minutes.

3. Inoculation and incubation of media. The inoculum for the shaker flasks was prepared from cells of $\Lambda$. gossypil grown on stock agar slants for $2 / 4$ to 72 hours depending upon the experimental conditions being studied. In the early experiments, the inoculum was prepered by washing the cells from each slant with approximately $10 \mathrm{ml}$. of sterile distilled water and breaking up clumps with the inoculation loop. This cell suspension was transferred to a sterlle, $15 \mathrm{ml}$. centrifuge tube, centrifuged, washed twice with $10 \mathrm{ml}$. of fresh sterile distilled vater and resuspended in $10-12 \mathrm{ml}$. of sterile distilled water. A volume of $0.2-0.3 \mathrm{ml}$. of the weshed cell suspension was used to inoculate each shaker Mlask. In later experiments, the suspension, before being washed, was shaken with sterile glass beads to provide a more uniform inoculum. The flask of inoculated experimental media vere incubated on the 
shaker In a constant temperature room at $28^{\circ} \mathrm{C}$. for a given perlod of time, in most cases, for 96 hours. Solid media slants were incubated at the same temperature as the Flasks for the desired length of time.

4. Measurement of growth. Orowth was measured by turbidimetric measurements or by obtalning the weight of the dry cells. Turbidimetric measurements were carried out in the Evelyn photoelectric colorimeter using the 540 millimicron green filter. The instrument was set at 100 per cent transmittance with a distilled water blank and the value of an air blank was determined with this setting. Further adjustments of the instrument were made by setting the instrument on the air blank reading throughout each set of determinations. After incubation each culture was adjusted to the original volume of $20 \mathrm{ml}$. with distilled water and then added to a colorimeter tube which was placed in the colorimeter. The growth was measured as per cent transmittance which varied inversely as the amount of growth present. The readings were nade within a few seconds after the suspensions were prepared because the cells tended to pack to the bottom of the tube. The method was rapid and reasonably accurate at lower concentrations of cells, however, at higher concentrations of cells it was difficult to measure differences in growth.

The determination of the dry weight of cells was accomplished as follows: the medium containing the cells was diluted to the original volume of $20 \mathrm{ml}$. After therough mixing, a $10 \mathrm{ml}$. aliquot of a suspension was removed for riboflavin determination and the remaining portion of the suspension was suction filtered onto a previously dried and weighed fllter paper. After the cells and filter paper were washed with distilled 
water, they were placed in an oven at $105^{\circ} \mathrm{C}$. to dry for 12 hours. The dried cells and paper were reweighed and the dry weight of cells per $10 \mathrm{ml}$. of allquot was deternined by difference. The dry weight method provided a more accurate meang of measuring growth than the turbidimetric method.

\section{c. Riboflavin Determination}

1. Preparation of the sample for riboflavin determination. The riboflavin was extracted from the cells of $\Lambda$. gossypif by autoclaving them for 30 minutes at 15 pounds steam pressure. Befors extraction, $2.5 \mathrm{ml}$. of $0.123 \mathrm{M}$ sodium acetate buffer, at pH 4.7 , wes added to each $10 \mathrm{ml}$. of the growth medium containing cells. The buffer was added to stabilise the riboflavin during extraction, since 1 would be rapidly destroyed in near neutral or alkaline solutions. The autoclaved mixture was filtered to remove the cells and the filtrate was diluted to an appropriate volume, usually $25 \mathrm{ml} .$, with distilled water. The necessary dilutions were made from this solution before the riboflavin determinations were made.

\section{Fuorometric determination of riboflavin. The fluorometric} determination of riboflavin described by the Association of Vitanin Chemists (6) was modifled to adapt it for use with the Universal spectrophotometer. Fluorescence was measured by readings on the per cent transrittance scale of the instrument. The standard solutions were made from a standard stock solution which wes prepared by dissolving $25 \mathrm{mg}$. of riboflavin in $1000 \mathrm{ml}$. of a solution containing $2 \mathrm{ml}$. glacial acetic acid. Ten milliliters of each diluted unknown riboflevin solution and of the 
standard solution were added to separate test tubes each of which contained $1 \mathrm{ml}$. of glacial acetic acid. After thoroughly mixing the solutions, each solution was transferred to a special microcuvette and fluorescence measurements were made. Duplicate determinations were made for each uniknown or standard riboflavin solution. The cuvettes were rinsed thoroughly with distilled water and dried after each determination.

The fuorometric deternination of riboflavin was made on a Epecially adapted Univeras Spectrophotometer. The instrument was adjusted to zero per cent trenamittance using a water blank, then using a solution containing 50 ug. of sodium fluoroscein per liter of distilled vater as a substitute standard, the Bal dial was set at a per cent transulttence for reference, usually between 40 to 60 per cent, and then the index of the galvanometer scale vas adjusted to read sero with the nuorometer knob of the instrument. During the assay, frequent checks were made with the sodium fluoroscein solution by readjusting the instrument to the reference transmission selected in order to maintain standardized conditions. A water-dithionite blank value was deternined on a solution of $10 \mathrm{ml}$. of diatilled water and $1 \mathrm{ml}$. of glacial acetic acid containing approxdmately $20 \mathrm{mg}$. of sodium dithionite.

After the fluorescence of a ribollavin ample was measured, approximately $20 \mathrm{mg}$. of sodium dithionite was added to the ample in the cuvette and thoroughly mixed. The dithionite reduced the riboflavin to the colorless form and the sample was again measured to determine the Nuorescence by substances other than riboflavin in the reduced sample. The water-dithionite blank value was subtracted from the fuorescence of the reduced ribollavin sample to give the correction for the Anorescence 
of non-riboflavin substances present in the untreated sample. The fluorescence due only to riboflavin in the sample was determined by subtracting the correction for the non-riboflavin fluorescence from the fluoresence of the untreated sample. A geries of standard riboflavin solutions vere measured in order to calibrate the instrument and to prepare a standard curve. The standard stock solution was diluted to give duplicate solutions ranging in concentration from 0 ug. to 1 ug. of riboflavin per ml. The results of a standard calibration determination are shown in Table 1 and the data plotted as a standard curve in Figure 2.

\section{IABLE 1}

THE FLUORESCENCE OF STANDARD RIBOFLAVTI SOLUTIONS

\begin{tabular}{|c|c|c|c|c|c|}
\hline \multirow{2}{*}{$\begin{array}{l}\text { Riboflavin } \\
\text { Solutions } \\
\text { (ug/ml) }\end{array}$} & \multicolumn{5}{|c|}{$\begin{array}{l}\text { Fluorescence } \\
\text { (Dial Readings) }\end{array}$} \\
\hline & Untreated & Reduced & Correction & Riboflavin & Average \\
\hline $\begin{array}{l}0.05 \\
0.05\end{array}$ & $\begin{array}{l}76.2 \\
76.6\end{array}$ & $\begin{array}{l}73.9 \\
73.8\end{array}$ & $\begin{array}{l}0.1 \\
0.0\end{array}$ & $\begin{array}{l}76.1 \\
76.6\end{array}$ & 76.3 \\
\hline $\begin{array}{l}0.10 \\
0.10\end{array}$ & $\begin{array}{l}79.2 \\
79.1\end{array}$ & $\begin{array}{l}73.9 \\
74.0\end{array}$ & $\begin{array}{l}0.1 \\
0.2\end{array}$ & $\begin{array}{l}79.1 \\
78.9\end{array}$ & 79.0 \\
\hline $\begin{array}{l}0.30 \\
0.30\end{array}$ & $\begin{array}{l}89.1 \\
89.0\end{array}$ & $\begin{array}{l}73.9 \\
74.0\end{array}$ & $\begin{array}{l}0.1 \\
0.2\end{array}$ & $\begin{array}{l}89.0 \\
88.8\end{array}$ & 88.9 \\
\hline $\begin{array}{l}0.50 \\
0.50\end{array}$ & $\begin{array}{l}98.0 \\
98.2\end{array}$ & $\begin{array}{l}73.9 \\
74.0\end{array}$ & $\begin{array}{l}0.1 \\
0.2\end{array}$ & $\begin{array}{l}97.9 \\
98.0\end{array}$ & 98.0 \\
\hline $\begin{array}{l}0.75 \\
0.75\end{array}$ & $\begin{array}{l}108.7 \\
109.2\end{array}$ & $\begin{array}{l}73.9 \\
74.0\end{array}$ & $\begin{array}{l}0.1 \\
0.2\end{array}$ & $\begin{array}{l}108.6 \\
109.0\end{array}$ & 108.8 \\
\hline $\begin{array}{l}1.0 \\
1.0\end{array}$ & $\begin{array}{l}119.6 \\
119.8\end{array}$ & $\begin{array}{l}73.9 \\
74.0\end{array}$ & $\begin{array}{l}0.1 \\
0.2\end{array}$ & $\begin{array}{l}119.5 \\
119.6\end{array}$ & 119.6 \\
\hline
\end{tabular}

* - Average water-dithlonite blank value 73.8 .

* - Correction for non-ribonavin fluorescence. 


\section{rrovis 2}

A STANRARD RTBORLATIN CURY 


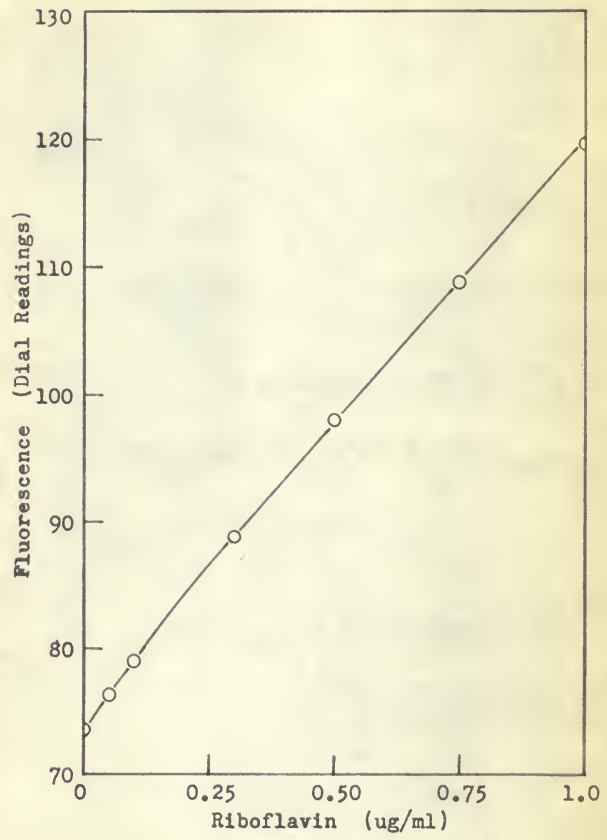


Since the curve In Figure 2 showed that the most desirable concentrations of riboflavin for the determination were between 0.3 ug. and 1.0 ug. per ml., dilutions of unknown samples were made to give concentrations which would fall within this desired range. The unknown samples were treated in the same manner as the standard samples above, fluorescence readings were made and anounts of riboflavin were read from the standard curve prepared for each series of unknown determinations. 1Ithough the fluorometric method gave good results, it required 4 to 6 hours to make one complete assay of a serles of amples, therefore, it placed a limit on the number of experiments which could be performed at one time.

\section{Chromatogrephy}

1. Paper sheets and strips. The conventional methods of ascending paper chromatography were employed with sheets or strips of Whatman Ilo. 1 filter paper. The butanol-acetic acid-water and the pyridine-tert. anyl alcohol-water solvents were used as the resolving systems. Small sheets, $18 \mathrm{~cm}$. by $18 \mathrm{~cm}$, were formed into cylinders and run in large mouth jars. The cylinder was held in form by a nichrome wire shaped in the form of a mall crescent. The spots were developed by ultraviolet light, ninhydrin solution or other standard developing solution. The amall twodimensional chromatograms could be completed in 7 to 8 hours as compared to at least 48 hours for the standard lange sheots.

2. Circular chrometography. The technique of circular chronatography was exployed as a rapid means of chromatographic separations and for the identiflcation of component fractions present in a solution. 
Circles of Whatman No. 1 filter paper, $20 \mathrm{~cm}$. In diameter, were cut Into quarters and a vick, approximately $2 \mathrm{~mm}$, wide, was cut from the are side of the quarter to the center of the quarter. The solution, to be chromatographed, was applied at the bend where the wick and the paper connected. As in all paper chromatograms, the smallex the gpot of application, the better the resolution of the components. The chromatographic chamber vas nade of two $9 \mathrm{~cm}$. fluted watch glasses, one to serve as the solvent reservols and the other as the top. Apter 5 to $6 \mathrm{ml}$. of solvent had been added to the reservoir, the wick was bent down and placed in the solvent with the remainder of the paper resting on the watch glass. The watch glass top was put in place and the chromatogram allowed to Nlow as a circular migration from the wick in the center of the paper. The chromatogram was removed from the solvent when the solvent front had progressed 25 to $30 \mathrm{~mm}$. from the point of application. The solvent front was marked and the paper dried, sprayed and developed according to standard procedures. The $R_{f}$ values of the ring spots were measured in the conventional manner by dividing the ring distance by the solvent front distance. Solutions of amino acids and peptides, prepared by adding $50 \mathrm{mg}$. of the Individual amino acid or peptide to $100 \mathrm{ml}$. of distilled water were chromatographed. In Table 2, the $R_{P}$ values of amino acids and peptides are recorded for circular chromatograns using the solvent systems, n-butanol-acetic acid-water and pyridine-tertiary anyl alcohol-watex. The ring spots vere developed with a spray solution of ninhydrin.

3. Column chromatography. Column chromatography was used in the separation of peptone into different fractions. The column was made of a standard $50 \mathrm{ml}$. burette, however, a pyrex glass condenser tube, $250 \mathrm{~mm}$. 
TABLE 2

THE $R_{P}$ VALUES OF AMTNO ACIDS AND PEPTIDES IN BUTANOLACETIC ACID NATER AND PYRTDIVI-TERTIARY AMYL ALCOHOL-WITER SOLVENIS ON CIRCULAR CHROMATOGRAMS

\begin{tabular}{|c|c|c|c|}
\hline \multirow[b]{2}{*}{$\begin{array}{l}\text { Amino Acids and } \\
\text { Peptides }\end{array}$} & \multicolumn{2}{|c|}{$\mathrm{R}_{\rho}$ Values } & \multirow[b]{2}{*}{$\begin{array}{c}\text { Ninhydrin } \\
\text { Color }\end{array}$} \\
\hline & BuOH-HAc-Water & $\begin{array}{l}\text { Pyridine-t-anyl } \\
\text { alcohol-Water }\end{array}$ & \\
\hline alpha-Alanine & 0.47 & 0.50 & Red-purple \\
\hline betadlanine & 0.43 & 0.44 & Purple-blue \\
\hline Arginine-HICl & 0.34 & 0.34 & Purple \\
\hline Asparagine & 0.39 & 0.38 & Brown \\
\hline Aspartic Acid & 0.38 & 0.37 & Purple \\
\hline Cystine-HCl & 0.33 & 0.31 & Purple \\
\hline Glutamie Acid & 0.50 & 0.41 & Red-puxple \\
\hline Glyeine & 0.41 & 0.43 & Purple \\
\hline Histidine-HCI & 0.36 & 0.44 & Blue-purple \\
\hline Isoleucine & 0.74 & 0.70 & Purple \\
\hline Leucine & 0.77 & 0.70 & Purple \\
\hline Lysine-HCI & 0.38 & 0.31 & Red-purple \\
\hline Methionine & 0.64 & 0.66 & Purple \\
\hline Phenylalanine & 0.72 & 0.71 & Purple \\
\hline Proline & 0.51 & 0.54 & Iollow \\
\hline Serine & 0.44 & 0.46 & Purple \\
\hline Threonine & 0.50 & 0.51 & Red-purple \\
\hline Tryptophsne & 0.68 & 0.69 & Purple \\
\hline Tyrosine & 0.60 & 0.66 & Red-purple \\
\hline Vallne & 0.64 & 0.61 & Red-purple \\
\hline Alanylphenylalanine & 0.77 & 0.70 & $\begin{array}{l}\text { Brown, turns } \\
\text { pink }\end{array}$ \\
\hline Glyeylglycine & 0.44 & 0.36 & $\begin{array}{l}\text { Brown, turns } \\
\text { pinis }\end{array}$ \\
\hline Glycjlalantne & 0.70 & 0.61 & $\begin{array}{l}\text { Brown, turns } \\
\text { pink }\end{array}$ \\
\hline
\end{tabular}

* - Average of duplicate measurenents.

by $10 \mathrm{~mm}$., can be used when fltted with a removable stopcock at the narrow end. Approxdmately one-hale inch of glass wool was packed into the botton of the column to retain the material forming the stationary phase of the coluran. In the experiments with peptone, Whatman powdered cellulose was 
used as the stationary phase. Approxdmately 8 grams of powdered cellulose vas suspended in the butanol-acetic acld-water solvent and carefully added to the column. The column was allowed to pack by the now of the solvent through the cellulose, taking care to tap the air bubblea out as the column formed. It is important to keep the solvent level above the top of the cellulose since once the cellulose becomes free of the solvent, a pocket of air forms thus deatroying the unifornity of the atationary phase. After 211 of the cellulose was paciced into the column it was washed w1th 50 to $60 \mathrm{ml}$. of fresh solvent. The solvent was allowed to run through the column until it was about $1 \mathrm{~cm}$. frome the top of the cellulose and at this point the stopeock was shut off.

The peptone was prepared by dissolving about $1.0 \mathrm{~g}$. of Difco-peptone in a minimum amount of water. The peptone solution was mixed with powdered cellulose to form a paste which was dried at $75^{\circ} \mathrm{C}$. for about 30 minutes. The peptone-cellulose mixture vas added to the top of the cellulose colum and carefully packed. Fresh solvent was run into the column and the stopcock opened to allow a flow of the solvent to pass through the cellulose. Samples of the effuent from the column were checked perlodically by wetting a filter paper strop, drying 1 and spraying it with ninhydrin solution to show the appearance of the ninhydrin positive portions of peptone. After the first indication of ninhydrin positive material in the effluent, fractions were collected from the column every 3 to $4 \mathrm{ml}$. Circular chromatograms were wade of each fraction as it was collected which provided an indication of the progress of the separation on the column. This speeded up the entire procedure, so that similar fractions could be comblned as the separation wes taking place. This application of circular chromatography 
served to stress the utility of the technique in cases where a rapid chromatographic interpretation of mixtures is desired.

\section{E. Fuxperinents}

1. The Relationship of Riboflavin Synthesis to Growth in a Peptone Kedium. The work of Tanner, et 르., (100) with A shbye gossypili has shown that riboflavin synthesis did not begin until after the organisa had grown for approximately 48 hours. They suggested that riboflavin may be synthesized only after the organism had reached a certain stage of growth but gave no data to indicate at what stage of growth the synthesis started. This experiment was undertaken to show the relationship of riboflavin synthesis to the growth of 4 . gossypil.

A liquid medium was prepared which contained 2.0 per cent glucose, 0.5 per cent peptone, 0.1 per cent $\mathrm{KH}_{2} \mathrm{PO}_{4}, 0.1$ per cent $\mathrm{K}_{2} \mathrm{HPO}, 0.05$ per cent $\mathrm{MgSO} / 4.7 \mathrm{H}_{2} \mathrm{O}$ and 0.05 per cent $\mathrm{NaCl}$, in $100 \mathrm{ml}$. distilled water. The medivm was adjusted to pH 6.5 and autoclaved in $250 \mathrm{ml}$. Erlenmeyer Rlasks. Twenty flasks containing the sterilized medium were inoculated with a 48 hour washed cell suspension of $A$. Bossryplit in the usual manner. Two flasks were used for the duplleate zero time determinations. The rest of the flasks were Incubated on the shaker. Two Nasks were removed from the shaker after each of the following time Intervals: $8,12,18.5,24,29$, $36,48,72$ and 96 hours. The contents of each flask were diluted to $20 \mathrm{ml}$., the original volume, and transferred to a colorimeter tube and the turbidity determined by measuring the per cent transmittance. The plil of the contents of each tube was determined next, followed by the addition of $5 \mathrm{ml}$. of acetate buffer and extraction of the riboflavin. The extracted cells were 
filtered onto previously weighed f1lter papers and drled for dry weight determinations of the extracted cells. Each filtrate was removed and diluted to the appropriate concentration range and the ribollavin was determined fluorometrically. The results of the experiment are given in Table 3 and are shown graphically in Tigure 3.

The growth of A. gossypif follows a pattern typical of most microorganians, as shown by the turbidometric growth curve in Figure 3. After a 6 hour lag period, the growth increases rapidly for a 10 to 12 hour period which corresponds to the logarithnic phase of growth. At this phase, growth slowly begins to level off and reaches a maximum between 38 and 45 hours. The growth, as determined by the dry weights of extracted cells, follows a pattern simllar to that determined tarbidimetrically, reaching a maxdmum dry weight at 36 hours. The dry weights of extracted cells decrease rapidly from 36 hours to the flnal determination at 96 hours, which is approxinately 5 th per cent of the maximum dry weight. This probably indicates a greater disruption of the cells during the extraction procedure with the resultant loss of intrecellular materials. This is to be expected since older cells are known to be more easily affected by physical environment. In the work of Mac Leren on I. ashbyi1, the dry weight of extracted mycella was used as an indication of growth for comparing the effects of various purines and pyrimidines in different media. On the basis of the experiment just discussed, there may be some question whether the dry weights of extracted cells could be validly used as a true measure of growth. A better indication of the true growth of the organiam might be obtained by taking the dry weighta of an aliquot of cells before the extraction of riboflavin. 
TABLE 3

THE PER CENT TRANSMITTANCE, PH AND RTBOFLAVIN CONTEDT OF CULTURES OF A. GOSSIPII, AND DRY WTIGHTS OF THEIR EXTRACIED CELIS,

AT DIFFERENT AGES GROWN IN A PEPTONE MEDIUM

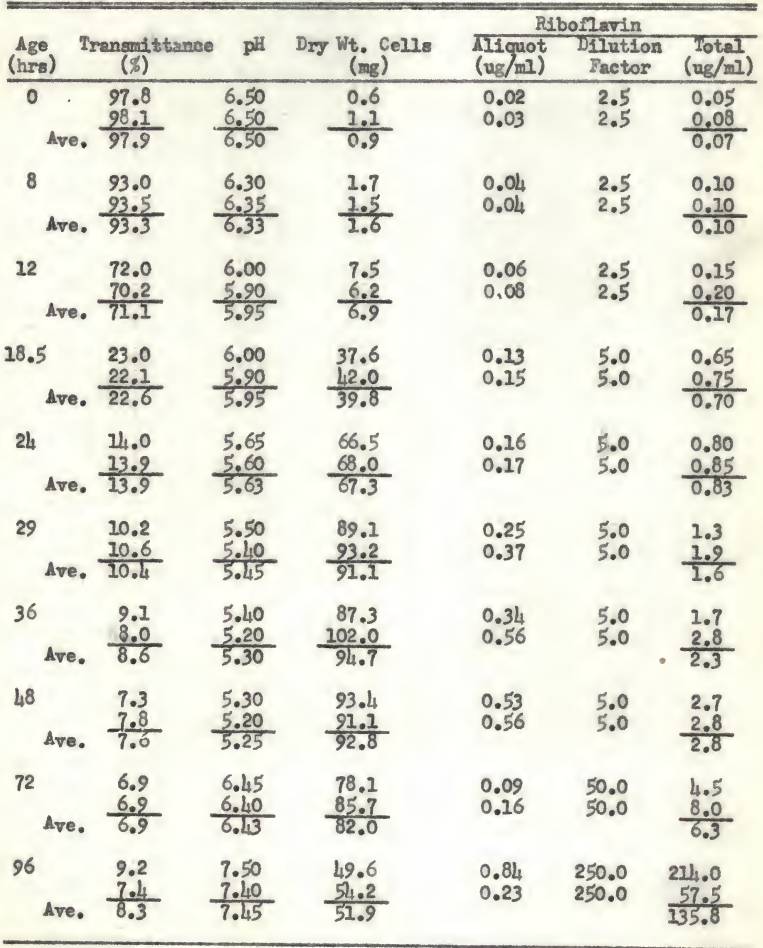


FICUR 3

THE RERATIONSHIP OF GRONTH, PH AND RIBOFLAVIN CONTENT OF CULTURES

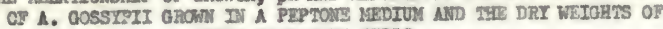
THETR EXIRACTED CELLS 
39
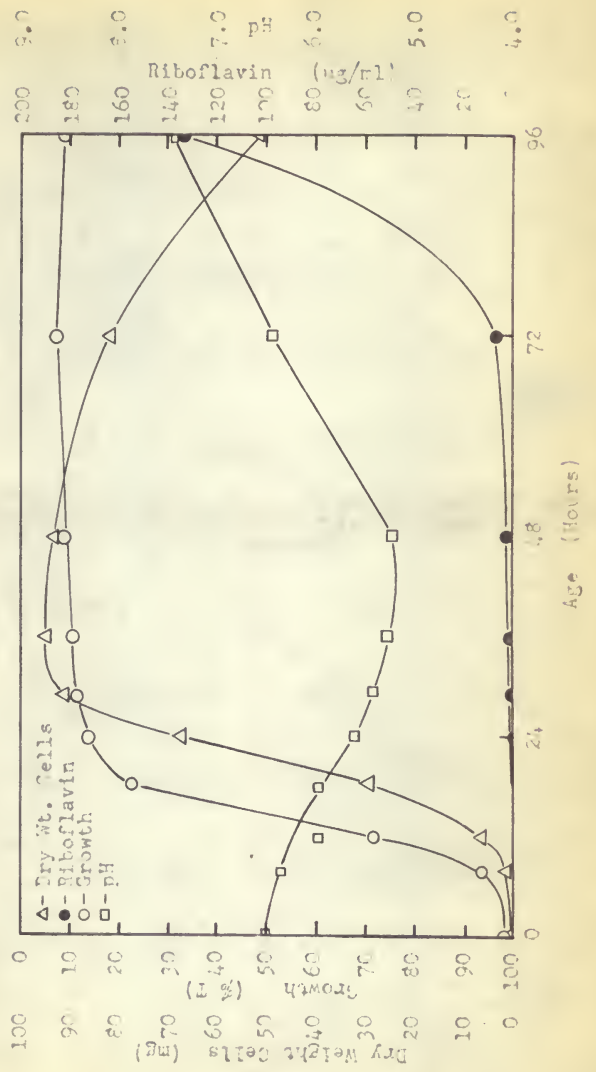
There is no indication of riboflavin synthesis until after the Iirst 24 hours. The synthesis proceeds slowly until at 72 hours there Is a very rapid increase in the production of the vitamin. As Figure 3 shows, riboflavin is not synthesized in appreciable anounts until several hours after the maximum growth has been reached. The data leaves little doubt that riboflavin synthesis occurs after meximun growth in a glucosepeptone mediur.

The changes in pll during growth were the same as those described by Tanner, et el., (100). During the first 36 to 40 hours of growth, there is a gradual decrease in pll to a value of approximately 5.3. The phl shows a rapid increace after 45 hours reachlng a value of phl 7.45 at 96 hours. It is to be noted that the pll increase closely parallels the increase in riboflavin eynthesis. It hes not been determined whether the pil Increase is a result of ribollavin synthesis or riboflavin synthesis is a result of the changes ceusing the pil increase. It is poesible in the peptone medium that the concentretion of some intermediate related to ribollavin synthesis must reach a critical value before the Vitamin production can begin and that the cells must be of a certain age or stage of growth before this limiting intermediate can be made avaliable to the riborlavin synthesizing mechanisms of the cells.

\section{The Fractionation of Peptone on a Cellulose Column. A sample} of Difco-peptone was fractionated on a Whatman powdered cellulose column, in order to determine which anino acid or peptide components vere assoclated with the formation of ribollavin by 1 . gossypif. The column was prepared according to the procecure previously given. The eluate was collected in tubes, memually, every 3 to $4 \mathrm{ml}$, until a total of 40 separate 


\section{1}

volumes had been collected. The liquid in oach tube was chromatographed With the circular chromatography technique as it was collected from the colum. R $R_{f}$ values of components were calculated and tubes with components having the same $R_{f}$ value were combined. The $R_{f}$ values and the tubes that were combined are shown in Table 4.

\section{TABLE 4}

THE $R_{f}$ VALUES OF CHROMATOGRAPHICALLY SEPARA TED FRACTIONS OF PEPTONE

\begin{tabular}{ccc}
$\begin{array}{c}\text { Fraction } \\
\text { Number }\end{array}$ & $\begin{array}{c}\text { Tubes } \\
\text { Combined }\end{array}$ & $\begin{array}{c}\text { Average Rf Values } \\
\text { of the Rings }\end{array}$ \\
\hline I & $1-7$ & 0.78 \\
II & $8-10$ & $0.75,0.57$ \\
III & $11-13$ & $0.72,0.57,0.41$ \\
IV & $15,16,18$ & $0.58,0.41,0.30$ \\
V & $19-30$ & $0.36,0.27$ \\
VI & $31-34$ & Approx. 0.27 \\
VII & $35-40$ & Very faint ring
\end{tabular}

The fractions were concentrated to dryness over $\mathrm{CaCl}_{2}$ in a vacuum desiccator at room temperature. The $R_{f}$ values of the fractions indicated that peptone contained at least four distinct components.

\section{The Growth and Riboflavin Production of A. gossypil with}

Peptone Fractions as Nitrogen Sources. The peptone fractions obtained in the previous experiment were used as n1trogen sources for studying the growth and the formation of riboflavin by A. gossypi1. The standard basal 
mediun with 0.05 per cent Instead of 0.1 per cent $\mathrm{NaCl}$ was prepared as previously described and the different peptone fractions were added to the basel medium to give individual media which were storilized by autoclaving. The sterile media were Inoculated with a washed cell suspension of A. gossypi1 and placed on the shaker in the constant temperature room. A control with peptone as the nitrogen souree was run in the same way. After 96 hours, the flasks were removed from the shaker and examined visually for growth and rboflavin production (the formation of yellow pigment). The growth and pigmentation were estimated on the basis of an arbitrary maxdmum value of +4 for the peptone control. The lower values were in proportion to the control value, with the designation \pm indicating a value slightly less than the corresponding + value. The results obtalned are shown in Table 5.

\section{TABLE 5}

THE GROWTH AND PIGARTIATTON OF ASHBYA GOSSYPII ON MEDIA CONTAININO PEPTONE FRACTIONS AS ATTROGEN SOURCES

\begin{tabular}{ccc}
\hline $\begin{array}{c}\text { Fraction } \\
\text { Number }\end{array}$ & Growth & Pignentation \\
\hline I & +4 & \pm 1 \\
II & +3 & 0 \\
III & 0 & 0 \\
IV & +4 & \pm 1 \\
V & +4 & 0 \\
VI & +4 & +3 \\
VII & +2 & 0 \\
Peptone Control & +4 & +4 \\
\hline
\end{tabular}


The growth compared favorably with the control in all fractions except III and VII. Fraction VI was the only fraction which showed any appreciable pigmentation, however, there was evidence of alight pigmentation In fractions I and IV. It appears that fraction VI contains the camponent or couponents which account for the stimulation of riboflavin synthesis when peptone is used as a nitrogen source. It is to be noted that this fraction contained the low $R_{I}$ value ninhydrin positive components which would Indicate the presence of besic andno acids and/or peptides, under the chromatographic conditions employed.

4. The Proximate Cualitative Chromatographic Analygis of the Amino Ac1ds in the Peptone Fractions. In order to obtain some indication of the amino acids present in the peptone fractions, portions of the fractions were hydrolysed with $6 \mathrm{~N} \mathrm{HCl}$ in seeled glass tubes by autoclaving at 15 pounds steam pressure for 30 minutes. Portions of the hydrolyzates were chromatographed by the circular technigue and the $R_{f}$ values calculated for the resulting rings. These $\mathbb{R}_{f}$ values were compared with those for the known anino acids in Table 2 to find the amino acids that were possibly present. No effort was made to identify the individual anino acids. The results are presented in Table 6. The Rf velues of these rings may vary slightly from the values of the pure anino acids since 1nteractions among the amino acids and their hydrochloride salts will affect the migration; however, relative locations of the rings can be compared with the known locations of the pure amino acids.

The chromatogrem of fraction VI, the fraction which allowed appreciable pigmentation, showed that the concentration in the three rings 


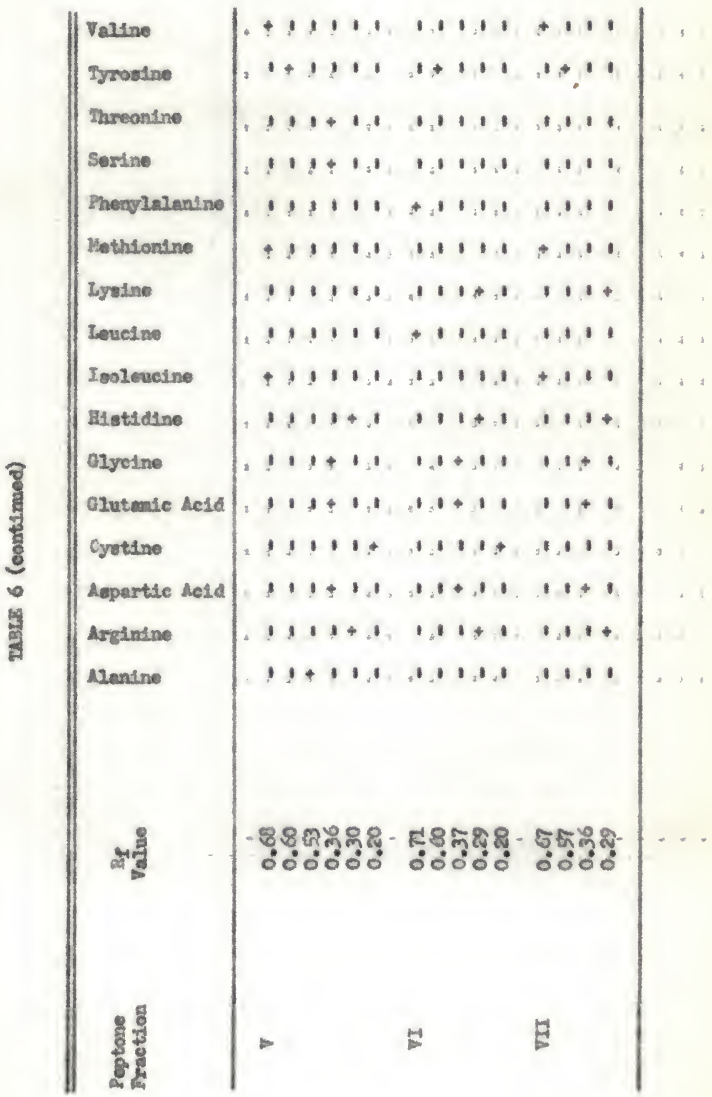


of lower $\mathrm{H}_{f}$ value was much greater than the comparable rings of and of the other Iractions. These rings indicate the possible presence of the dicarboxylic and basic arino acids, which would indicate a relattonship between these amino aclids and riborlavin formation in $\mathbf{A}$. gossypif. However, compounds other then amino acids could be present in this frection and exert some effect on the oynthesis of the vitamin.

5. The Effect of Various Amino Acid Conbinations on the Growth and Riboflavin Formation of A. gosszpif. The previous experiment presented some ev1dence that certain amino acids vere concentrated in the fraction of peptone which gave appreciable pigmentation with $\mathbb{A}$. gossxpif. These amino acids, in various combinations, were used as nitrogen sources in a series of media in order to determine if combinations of pure amino acids could stimulate the growth and pigmentation obtained on peptone. The basal medium was prepared with 0.05 per cent $\mathrm{NaCl}_{\mathrm{a}}$ and the amino acids were added in various concentrations to give a constant $L O \mathrm{mg}$. of nitrogen per $100 \mathrm{ml}$. of each medium. The nitrogen vas determined on the basis of Lmanino acids present in each medium. After the addition of the amino aclds, the pH was adjusted to $6.5-6.8$ and the media sterlilged by autoclaving. The amino acid composition of the medis are given in Table 7. Since arginine seemed to be present in each peptone fraction it was arbitrarily chosen as the initial anino acid of the series which was tested.

The sterile media were inoculated with a 36 hour vashed cell suspension of A. gossypil and incubated on the shaker in the constant temperature room. The media were examined in the same manner as in the previous experiment at various time intervals to estimate the growth and 


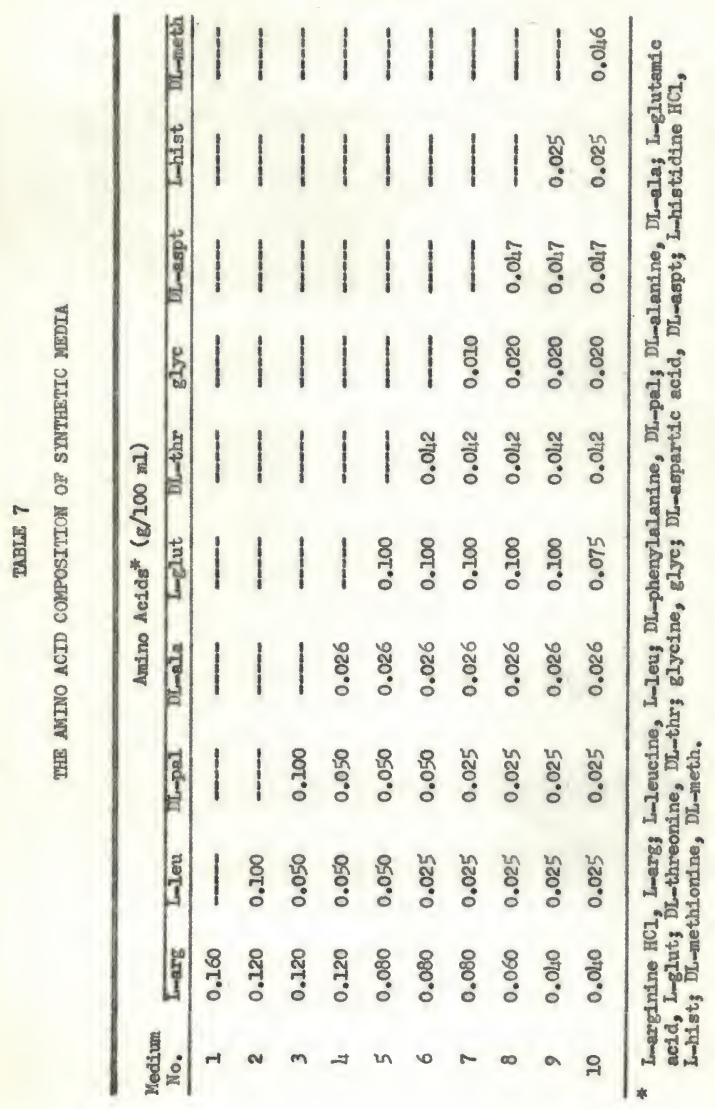


48

pigmentation. The results are presented in Table 8 ,

TABLE 8

THE BFFECT OF ANINO ACID CONBINATIONS ON GROWTH

AND PIGMENTATION OF ASHBYA GOSSYPII

\begin{tabular}{|c|c|c|c|c|c|c|c|c|}
\hline \multirow{3}{*}{$\frac{\begin{array}{c}\text { Medium } \\
\text { No. }\end{array}}{1}$} & \multicolumn{8}{|c|}{ Time } \\
\hline & \multicolumn{2}{|c|}{$\frac{24 \text { hours }}{\text { Growth Pigment }}$} & \multicolumn{2}{|c|}{$\frac{48 \text { hours }}{\text { Growth PIgment }}$} & \multicolumn{2}{|c|}{$\frac{72 \text { hours }}{\text { Growth PIgment }}$} & \multicolumn{2}{|c|}{$\begin{array}{l}96 \text { hours } \\
\text { Growth Pigment }\end{array}$} \\
\hline & 81 & 0 & \pm 1 & 0 & +2 & 0 & +3 & 0 \\
\hline 2 & +1 & 0 & +2 & 81 & +2 & 81 & +4 & +1 \\
\hline 3 & 81 & 0 & $s 1$ & 0 & +1 & 0 & +2 & 0 \\
\hline 4 & 81 & 0 & +1 & 0 & +1 & 0 & +3 & s1 \\
\hline 5 & +1 & 0 & +2 & 0 & +3 & 0 & +4 & 0 \\
\hline 6 & +2 & 0 & +3 & 0 & +4 & 0 & +4 & 81 \\
\hline 7 & +2 & 0 & +3 & 0 & +4 & 0 & +4 & 81 \\
\hline 8 & +2 & 0 & +3 & 0 & +4 & sl & +4 & 81 \\
\hline 9 & +3 & sl & +4 & +1 & +4 & +2 & +4 & +3 \\
\hline 10 & +3 & 0 & +4 & 0 & +4 & 0 & +5 & 0 \\
\hline
\end{tabular}

At the end of the first 24 hours, medium number 6 showed an increased growth over the previous media, indicating that L-glutamic acid Is probably associated with the growth of the organiam. A similer increased growth wes noted with medium number 9 when L-histidine HCl was added. Medium number 9 also gave evidence of slight pigmentation which may relate histidine to riboflavin formation. After 48 hours, growth hed Increased in all the media except number 3 which may have been inhibited by DL-phenylalanine since the presence of D-anino acids does sometimes 
exert such effects. At 48 hours, pigmentation continued in medium mumber 9 and a slight coloration appeared in medium number 2 which contained only arginine and leucine as nitrogen sources. The final examination of the media at 96 hours indlcated good growth in all cases except medium number 3. There was slight pigmentation in media numbers $4,6,7$ and 8; moderate pigmentation in medium number 2 and appreciable plgmentation in mediun number 9.

The final results seen to indicate interaction effects of the anino acida which are present in the media. These effects could be the results of interferring concentrations or merely the presence of the amino acids themselves. When L-leucine was added to L-arginine HCl, pigmentation resulted which would seen to relate leucine to ribonavin formation but the addition of DL-phenylalanine to the leucine-arginine medium prevented the pigment formation which should have been expected to contimue. An even greater effect on riboflavin synthesis was shown by the addition of methionine which completely reversed the effect of histidine and Inhibited the riboflavin formation which had been denonstrated in medium number 9. It is evident that interactions must be taken into conIderation whenever combinations of amino acids axe used for studying riborlavin synthesis in 1 . gossypi1.

6. Further Studies of the Effects of Amino Acids on the Growth and Biosynthesis of Riboflavin by A. gossypif. In the preceeding experiment it was noted that the addition of histidine to the other anino acids resulted in an increased formation of riboflavin. This experiment was designed to study the effect of histidine further and to deternine which amino acid relationships were directly concerned with the formation of 
riboflavin by A. gossyoil. The standard basal medium with 0.05 per cent $\mathrm{NaCl}$ was used throughout the experiment and was designated as "basal". Since histidine seemed to be a stimulator for miboflavin synthesis, it was chosen as the base amino acid in the first part of the experiment and was added to the bessel 2.8 the hydrochloride in a concentration of $0.012 \mathrm{~g}$. or an equivalent of $2.24 \mathrm{mg}$. nitrogen, per $100 \mathrm{ml}$. of medium to make the base medium for studying the effects of other added amino acids. This base medium was distributed into Rlasks, into each of which except one was added singly the other amino aclds used. Thus one flask conteined histidine as the nitrogen source, whereas the other flasks contained histidine plus another anino acld. Control flasks were also set up for peptone as the nitrogen source and the basal alone without a nitrogen source. The media were adjusted to pH 6.5 with $\mathrm{NaOH}$ and sterilized. The sterile media vere inoculated with a 36 hour washed cell suspension and Incubated on the shaker for 4 days at $28^{\circ} \mathrm{C}$. After incubation the growth was estimated visually in the same manner 28 the previous experiment. The ribollavin was estimated visually by examining the flasks in a beam of ultraviolet light and estimating the amount of fluorescence as compared with that from peptone as +4 . This allowed the detection of a much maller concentration of pigment than could be determined by color. The composition of the media and the effects on growth and riboflavin formation are shown in Table 9.

Glutamic acid was the only amino ecld which showed a substantial stimulation of the growth of A. gossypil, however, the addition of leucine, alanine, threonine or asparagine did increase the growth slightly over the histidine alone. Only leucine and threonine exhibited any stimulating 


\section{TABLE 9}

THE EREECT OF ADDED ANINO ACIDS ON THE GROWTH AND RTBOFLAVIN FORMATION BY ASHBYA GOSSYPII IN A HISTIDINE BASE MEDIUM

\begin{tabular}{|c|c|c|c|c|c|}
\hline $\begin{array}{l}\text { Kedium } \\
\text { No. }\end{array}$ & Base Medium & 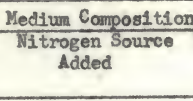 & $\begin{array}{c}\text { Concentration } \\
(\mathrm{g} / 100 \mathrm{ml})\end{array}$ & Growth & $\begin{array}{l}\text { Fluor- } \\
\text { escence } \\
\text { (ribo- } \\
\text { Ilavin) }\end{array}$ \\
\hline 1 & Basal & I-histidine $\mathrm{HCl}$ & 0.012 & +81 & 0 \\
\hline 2 & Ned. H1 & Inglutanic acid & 0.21 & +4 & 0 \\
\hline 3 & Ked. "I1 & I-leucine & 0.19 & +1 & 81 \\
\hline 4 & Med. \#1 & L-argInine $\mathrm{HCI}$ & 0.08 & sl & 0 \\
\hline 5 & Ned. II & Glycine & 0.11 & s1 & 0 \\
\hline 6 & Med. II & DL-aspartic acid & 0.39 & -1 & 0 \\
\hline 7 & Med. $\# 1$ & DL-alanine & 0.26 & +1 & 0 \\
\hline 8 & Med. 觔 & DL-threontne & 0.34 & +1 & 81 \\
\hline 9 & Med. II & DL-serine & 0.30 & 81 & 0 \\
\hline 10 & Med. "I 1 & Asparagine & 0.09 & +1 & 0 \\
\hline 12 & Basal & Peptone & 0.14 & +4 & +4 \\
\hline 12 & Basal & None & - & 0 & 0 \\
\hline
\end{tabular}

effect on pigment formation; however, the effect was anall. At the concentration used, it is evident that histidine cannot serve as the sole nitrogen source for growth and xiboflavin formation by A. gossypil.

Since these results indicated that good growth was obtained with L-glutanic acid and L-histidine HCI as nitrogen sources, the next part of this experiment was performed using these amino acids as the principal nitrogen sources. I-glutamic acid and L-histidine HCI were added to the 
basal to give $20.0 \mathrm{mg}$. and $2.4 \mathrm{mg} .$, respectively, of Imamino acid nltrogen per $100 \mathrm{ml}$. of medium to make the base medium for studying the effects of other added amino actds in this part of the experiment. This base mediun was distributed Into Naaks, into each of which except one was added singly the other amino acids used. Thus one flask contained glutamic acid and histidine as the nitrogen sources, whereas the other flasks contained glutanic acid, histidine and another amino acld. The media were adjusted to pH 6.5 with $\mathrm{NaOH}$, sterilized, Inoculated with a 36 hour washed cell suspension and incubated on the shaker for 4 deys at $28^{\circ} \mathrm{C}$. The composition of the media, and the results determined in the sane way as in the flrst part of the experiment are presented in Table 10.

The addition of I-histidine HCI to the glutanic acid medium resulted in decreased growth as compared to the glutanic acid medium. There was also decreased growth when DL-serine or glycine was added to the glutamic acid-histidine mediun, whereas the addition of L-arginine HCI increased the growth noticeably. Riboflavin formation occured to a slight extent when I-leucine or DL-threonine was added to the glutamic acidhistidine medium, however, the addition of DL-alanine or glyelne resulted in a moderate formation of the vitamin. The effects of alanine or glyeine are of interest, since neither of these amino acids has previously shown any effect on mboflavin formation when added to the histidine medium in the first part of the experiment.

In the last part of this experiment, a base medium was prepared by adding L-Glutanic acid, L-hist1dine HCl and L-arginine HCI to the basal for the nitrogen sources, since this combination of amino acids had given the best growth without riboflavin formation above. This base medium was 
THE FTFECT OF ADDED ANTNO ACTDS ON OROWTH AND RTBOFTAVIN SWNTHESIS IN A L-GLUTAMIC ACID - HISTIDINE HCI BASE YEDIUM

\begin{tabular}{|c|c|c|c|c|c|}
\hline \multirow[b]{2}{*}{$\begin{array}{l}\text { Medium } \\
\text { No. }\end{array}$} & \multirow[b]{2}{*}{ Base Kedium } & \multicolumn{2}{|c|}{ Medium Composition } & \multirow[b]{2}{*}{ Growth } & \multirow[b]{2}{*}{$\begin{array}{l}\text { Pluor- } \\
\text { escence } \\
\text { (ribo- } \\
\text { flavin) }\end{array}$} \\
\hline & & $\begin{array}{l}\text { Witrogen Source } \\
\text { Added }\end{array}$ & $\begin{array}{c}\text { Concentration } \\
(\mathrm{g} / 100 \mathrm{ml})\end{array}$ & & \\
\hline 1 & Basal & L-glutamic acid & 0.210 & +3 & 0 \\
\hline 2 & Med. ีㅗ 1 & I-histidine $\mathrm{HCl}$ & 0.012 & +2 & 0 \\
\hline 3 & Hed. Wh & L-leucine & 0.025 & +3 & 81 \\
\hline 4 & Med. \#2 & DL-threonine & 0.040 & +3 & $\mathbf{s}$ \\
\hline 5 & Med. \#2 & DL-serine & 0.032 & \pm 2 & 0 \\
\hline 6 & Med. $\frac{n}{\pi 2}$ & L-arginine $\mathrm{HCl}$ & 0.010 & +4 & 0 \\
\hline 7 & Med. 紊2 & DL-1soleucine & 0.050 & +1 & 0 \\
\hline 8 & Ked. Wh & DL-alanine & 0.035 & +3 & +1 \\
\hline 9 & Med. "I2 & Glycine & 0.015 & \pm 2 & +1 \\
\hline 10 & Med. \#2 & L-lysine $\mathrm{HCl}$ & 0.016 & +3 & 0 \\
\hline 11 & Basal & Peptone & 0.155 & +4 & +4 \\
\hline 12 & Basal & None & $-\ldots$ & 0 & 0 \\
\hline
\end{tabular}

used to study the effects of other added emino acids and was distributed Into flasks, into each of which except one was added singly the other amino acids used. This gave one Mlask which contalned glutamic acid, histidine and arginine as the nitrogen sources, whereas the other Nasks contained glutamic acid, histidine and arginine plus another amino acid. A peptone control flask was set up also. The media were adjusted to pH 6.5 with $\mathrm{NaOH}$, sterilized, inoculated with a 36 hour washed cell 
suspension and Incubated on the shaker for 4 days at $28^{\circ} \mathrm{C}$. The composition of the media, and the results determined in the same way as in the flrst part of the experiment are presented in Table 11.

\section{TABLE II}

THE ETRECT OF ADDED ANINO ACIDS ON GROWTH AND RIBOFLAVIN SYNTHESIS IN A GLUTAMIC ACID - HISTIDINE - ARGININE BASE VEDIUI

\begin{tabular}{|c|c|c|c|c|c|}
\hline \multirow{2}{*}{$\begin{array}{l}\text { Medium } \\
\text { No. }\end{array}$} & \multirow[b]{2}{*}{ Base Medium } & \multicolumn{2}{|c|}{ Medium Composition } & \multirow[b]{2}{*}{ Orowth } & \multirow{2}{*}{$\begin{array}{l}\text { Pluor- } \\
\text { escence } \\
\text { (ribo- } \\
\text { rlavin) }\end{array}$} \\
\hline & & $\begin{array}{l}\text { Hitrogen Source } \\
\text { Added }\end{array}$ & $\begin{array}{c}\text { Concentration } \\
(\mathrm{g} / 100 \mathrm{ml})\end{array}$ & & \\
\hline 1 & Basal & $\begin{array}{l}\text { L-glutamic acid } \\
\text { I-histidine } \mathrm{HCl} \\
\text { L-arginine } \mathrm{HCl}\end{array}$ & $\begin{array}{l}0.210 \\
0.012 \\
0.010\end{array}$ & +3 & 0 \\
\hline 2 & Med. $\# 1$ & I-leucine & 0.025 & +2 & +3 \\
\hline 3 & Med. \#1 & DL-threonine & 0.040 & +3 & si \\
\hline 4 & Med. \#1 & DI-alanine & 0.035 & +3 & \&1 \\
\hline 5 & Med. II & Qlycine & 0.015 & +3 & s1 \\
\hline 6 & Basal & Peptone & 0.172 & +4 & +3 \\
\hline
\end{tabular}

The growth of A. gossypil was good in all media except medium number 2 where the addition of L-leucine decreased the growth alightly. However, the addition of L-Ieucine increased the riboflavin formation sharply, approximately equaling that of the peptone control. The addition of DL-throonine, DL-alanine or glycine to medium number 1 gave only a slight formation of riboflavin.

This experiment has again served to point out the interaction effects of amino acids on the growth and riboflavin synthesis by Ashbye 
gossypi1. The results seem to indicate thet ribollavin synthesis is not just the result of one or two amino acids in the medium but rather the result of the combined action of several amino acids and other factors. L-glutanic ac1d, alone or in combination with L-arginine HC1 and amall. concentrations of L-histidine HCl, has been shown to adequately serve as a nitrogen source for the growth of $\mathbf{A}$. gossypif, however, it appears to have little direct effect on the synthesis of riboflavin. I-leucine showed some relationship to riboflavin synthesis as indicated by the increased riboflavin formation when it was added to the glutemic acidhistidine-arginine medium; however, a decreased growth was noted in this medium when appreciable ribollavin was formed. The results obtained with DL-threonine, DL-alanine and gljcine indicate some relationship to riboMavin formation but the effect of these amino acids may be masked by the presence of the other anino acids in the medium. If one can ascume that threonine, alanine and glycine are related to riboflavin formation, their lack of greater effect may be due to limited production of an essential link in the riboflevin synthesizing system, this link not being limiting when leucine was the amino acid added.

\section{The Effect of Serial Transfers of Cells of A. gossypl1 on} Synthetic Media, on Growth and Riboflavin Formation. Since the Inocula for the different experiments were prepared from cells grown on yeast extract-peptone agar stock slants, there was a possibility that some substance affecting riboflavin formation was being carried over in the inoculum even though the cells were washed two times with sterile distilled water. In order to test this possibility, it was decided to see $1 f$ such substances would be diluted by serial transfer on two types of synthetic 
media, media that support growth but not riboflavin formation and media that aupport both.

Several solid media were prepared from the basal with 0.05 per cent $\mathrm{NaCl}$, by adding different nitrogen sources including peptone as a control to give the compositions shown in Table 12.

TABLE 12

THE COMPSITION OF MEDIA FOR STUDYING THE EFFLCT OF SERIAL TRANSFER OF CETIS ON GRONTH AND RIBOFLAVIN FORYATION

\begin{tabular}{|c|c|c|c|}
\hline $\begin{array}{l}\text { Nedium } \\
\text { No. }\end{array}$ & $\begin{array}{l}\text { Base } \\
\text { Nedivm }\end{array}$ & $\begin{array}{l}\text { N1trogen Source } \\
\text { Added }\end{array}$ & $\begin{array}{c}\text { Concentration } \\
\text { Witrogen Source } \\
(\mathrm{g} / 100 \mathrm{ml})\end{array}$ \\
\hline 1 & Basal & Peptone & 0.178 \\
\hline 2 & Basal & $\begin{array}{l}\text { In-glutanic acid } \\
\text { L-arginine } \mathrm{HCl}\end{array}$ & $\begin{array}{l}0.210 \\
0.010\end{array}$ \\
\hline 3 & Med. ${ }_{2}$ & I-leucine & 0.025 \\
\hline 4 & Med. $\# 3$ & L-hist1dine $\mathrm{HCl}$ & 0.012 \\
\hline
\end{tabular}

The media were made solid by adding 1.8 per cent Difco-agar and were slanted after sterilization. Two slants of each media were inoculated with cells of A. gossypili taken directly from a 48 hour yeast extract-peptone agar slant without washing and were incubated at $28^{\circ} \mathrm{C}$. In the incubstor room. After four days, cells on these slants were trensferred to fresh slants of the same medium composition and were incubated. This procecture was repeated after another 4 days, making transfers to fresh slants giving a total of three transfers including the original transfer from the yeast extract-peptone agar slant. The growth 
was examined viraally and the riboflavin formation was estimated by observing the yellow fluorescence of the vitamin under ultravlolet light on all slants after being incubated 6 or 7 days. The results of the study are shown in Table 13.

\section{TABLE 13}

THE EFFECT OF SERIAL TRANSFGR OF CETIS OF ASHBYA GOSSYPII ON OROWTH AND RIBOFLAVIN FORNATION ON PEPTONE AND SYN 2 HETIC MEDIA

\begin{tabular}{|c|c|c|c|c|c|c|}
\hline \multirow{2}{*}{$\begin{array}{l}\text { Yedium } \\
\text { Mo. }\end{array}$} & \multicolumn{2}{|c|}{ First Transfer" } & \multicolumn{2}{|c|}{ Second Transfer } & \multicolumn{2}{|c|}{ Third Transfer } \\
\hline & Growth & Fivorescence & Growth & Tuorescence & Crowth & Fuorescence \\
\hline 1 & +4 & +4 & +4 & +3 & +4 & +3 \\
\hline 2 & +4 & 0 & +4 & 0 & +4 & 0 \\
\hline 3 & +4 & +2 & +4 & +2 & +4 & +2 \\
\hline 4 & +4 & +2 & +4 & +2 & +4 & +2 \\
\hline
\end{tabular}

* Orowth and Nuorescence after 6 deys incubation. *n Growth and Iuorescence after 7 days incubation.

The results auggest that there may be some carry over in the original transfor to the peptone mediun since there appeared to be a decreased pigmentation in the PIrat and second transfers. In the other media there was little indication of a carry over effect. In medis numbers 3 and 4 the pigmentation was noticeably scattered throughout the growth on the slant rather than being generally distributed as the pigmentation on the peptone slants. Th1s may indicate a localization of ribonavin formation on these synthetic media as a result of local deposition of some Ravogenic substance carried over from the preceeding mediun when the cells were streaked on the slants; however, this spotty 
plementation was approximately equal in distribution for all transfers. There was no pigmentation with any transfers on nedium number $2 ;$ hovever, the growth was equal to that of the other media.

To investigate further the possible carry over of substances that might have effects on growth or riboflavin formation, a eimilar test was made using Ifould media instead of the solld media. The procedure was the same as that for the solld medla except the agar was omitted and incubations were carried out on the shaker. In this case there was little difference noted among the first, second and third trenefers in peptone Nlasks, both with respect to growth and pigmentation. The other media showed good growth; however, in contrast to the slants, there was no ev1dence of rboflavin formation.

Since the first test indicated that there was a possibility of a carry over, another teat was carried out on a series of solid synthetic media containing different anino acids. The andno acids, Lomlutamic acid and L-arginine $\mathrm{HCl}$, in concentrations of $0.210 \mathrm{~g}$. and $0.010 \mathrm{~g}$. , respectively, per $100 \mathrm{ml}$. of medium, were added to the basal with 0.05 per cent $\mathrm{NaCl}$ to give a completely aynthetic medium which would support good growth of A. gossypif; however, it would not allow pigmentation. For purposes of clearity and brevity this glutemic ac1d-arginine mediun will be designated "GA". The GA medium served as the base medium and was distributed Into flasks Into each of which except one was added other anino acids singly and at a concentration of $0.015 \mathrm{~g}$. per $100 \mathrm{ml}$. of base medium. Thus one flask, as a control, contalned the $\mathrm{CA}$ medium and the other Ilask contained the GA medium plus aingle anino acids. The media were made into solld form by adding 1.8 per cent agar and the steriltzed agar was slanted. 
The original inoculation of the media was made from a 48 hour old yeast extract-peptone stock agar slant and subsequent transfers of the growth on the special media vere every 48 hours onto fresh special medis of the same corposition. A total of three transfers, including the original, . were made. The growth and pigmentation were examined as previously described except that a +5 value was arbitrarily chosen as the maxdmum growth value. The composition of the media and the results are recorded In Table H. $_{4}$

In general, the results indlcated that there was decreased growth in the second and third transfers as compared with the original transfer. The ribollavin formation followed a simllar pattern, occurring approxInately 24 hours later than the appearance in the orlginal transfer on similar media. Since the media in this experiment could not be considered optinum for the growth of the organism, it vould be expected that the second transfer after the orlginal would be slower in sterting growth since the necessary conditions for a rapid initial cell growth may not be avaliable. The appearance of the growth on the synthetic medsa slants was also very much different than the growth on the peptone medium slants. On the synthetic media the growth was very often tough and wrinkled with the aycelium growing tenaceously to the agar, naking it very difficult to transfer the cells to fresh slants. In contrast, the growth on a peptone slant was very soft and spongy, making it easy to remove cells from a slant with an Inoculation loop for transfer. These results show that there wes apparently a carry over of some aubstance or substances that had a slight effect on growth and rlboflavin formation, as was ahow by the difference between the flrst and second transfers. 
总

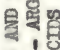

10

f

造

o

幽药

न

目年

웅

연몰

数空

연 홍

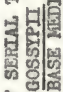

응 하

타의

越

谧

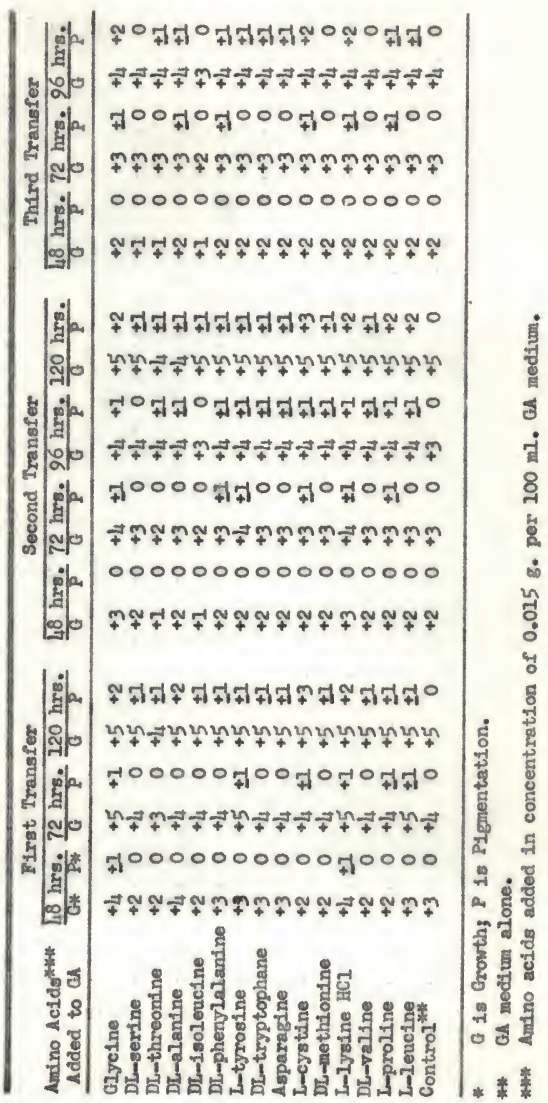


Since the growths and riboflavin formations were about the same for the second and third transfers, it seems that the substences were reduced in concentration by transfer.

On the agar slants, all of the amino acids, except valine, showed some stimulation of riboflavin formetion when they were added to the GA medium, however, there were variations in degree of effect on riboflavin formation. Of the amino acids used, Blyeine, DL-elanine, L-tyrosine, DL-tryptophane, L-cystine, L-lycine HCl, L-proline and L-leucIne exhibited the greatest stimulation of riboflavin synthesis.

In addition to the test just described, a study was made of the effect on riboflavin synthesis of serial transfers of A. gossypli cells in liquid $C A$ medium. The glutamic acid-arginine mediun was prepared from the basal medium with 0.05 per cent $\mathrm{NaCl}$ as previously described for the preparation of solld media except the 1.8 per cent Difco-agar vas amittod. The washed cells from a 48 hour culture of A. gossypif, grown on a yeast extract-peptone stock agar slant, were inoculated into the $\mathrm{GA}$ medium and shaken for 48 hours at $28^{\circ} \mathrm{C}$. Aftex this 48 hour period, the cells Irom the GA medium were removed, centrisuged, washed and resuspended as the Inoculum for the second transfer to fresh $G A$ medium which was again ahaken for 48 hours. At the end of the second 48 hour period of incubation the growth from the second transfer of cells was removed, centrifuged, washed and resuspended as the new Inoculum. These cells were inoculated into a peptone medium in which the basal had been supplemented with 0.5 per cent Difco-peptone as the nitrogen source. At the ane time that these serially trensferred cells were inoculated into the peptone mediwn, a peptone control was inoculated with washed cells from a yeast extract-peptone slent. 
The flasks were incubated for 5 days on the shaker at $28^{\circ} \mathrm{C}$. vith a set of five flaks used for each type of inoculum. The turbidimetric growth and fluorometric riboflavin deterninations were made on the flesks and the results obtained are shown in Table 15.

\section{TABLE 15}

THE GBOWTH AND RIBOFLAVIN FORMATION OF A. GOSSTPII ON A PEPTONE VIODIUS DFOCULATED WITH SERTAL TRANSFER CELLS

\begin{tabular}{|c|c|c|c|c|}
\hline \multirow{2}{*}{$\begin{array}{l}\text { Sarmple } \\
\text { Number }\end{array}$} & \multicolumn{2}{|c|}{ Control Cells } & \multicolumn{2}{|c|}{ Serial Transfer Cells } \\
\hline & $\begin{array}{l}\text { Turbidity } \\
\text { (\% trans.) }\end{array}$ & $\begin{array}{l}\text { Fitbor/ayln } \\
(\mathrm{uc} / \mathrm{ml})\end{array}$ & $\begin{array}{l}\text { Tyrbidity } \\
(\% \text { trans.) }\end{array}$ & $\begin{array}{l}\text { Riboflagt.n } \\
\text { (ug/mi) }\end{array}$ \\
\hline 1 & 8.4 & 22.1 & 8.3 & 30.0 \\
\hline 2 & 8.2 & 48.3 & 8.5 & 16.9 \\
\hline 3 & 8.2 & 31.8 & 9.5 & 22.5 \\
\hline 4 & 8.9 & 18.7 & 8.9 & 16.9 \\
\hline 5 & \multicolumn{2}{|c|}{ Contaninated } & 8.4 & 20.8 \\
\hline Average & 8.4 & 30.2 & 8.6 & 21.4 \\
\hline
\end{tabular}

The data in Table 15 show that the average growth was approxdmately the same in either case. The average gield of riboflavin was approximately 29 per cent greater in the peptone medium inoculated with the reast extractpeptone slant cells than in the peptone mediun inoculated with the serial transfer cells. The highest Individuel gield was also obteined with the yeast extract-peptone grown cells. It is to be noted, however, that although there was a large variation in the amounts of riboflavin found in the samples from elther source of inoculum, the variation was less in the medium inoculated with the serial trensfer celle. These date seem to 
Indicate that some factor or factors may be carrled over by the yeast extract-peptone agar grown cells; however, the effect would be expected to be constant throughout a particular experiment.

8. The Growth and Riboflavin Forzation of A, gossypli as

Affected by Inocula Prepared from Cells Subjected to Different Numbers of Washings. The studies on serial transfers of inocula indicated the possibility of a carry over effect on riboflevin synthesis from cells grown on the yeast extractmpeptone agar slants. If this factor vere loosely bound to the surface of the cells, It might be expected that differences in cells, obtained after a different number of washings, alght be demonstrated. This experinent was performed to see if such an effect covid be denonstrated.

The medium for this experiment was prepared from the cA medium to which was added $0.015 \mathrm{~g}$. of glyeine and $1.8 \mathrm{~g}$. of Difco-agar per $100 \mathrm{ml}$. of the mediun. The test cells were taken from a 48 hour stock slant of 1. Eossypl1 grown on yeast extract-peptone agar. Some of the cells from this stock slant were transferred to duplicate slants of the test medium. The rest of the cells vere washed with $10 \mathrm{ml}$. of distilled vater, centrifuged and resuspended in distilled water. The washings were repeated to obtain a total of four washings. Transfers of cells after each washing were made to duplicate slants of the test medium. All of the slants vere incubated at $28^{\circ} \mathrm{C}$. for 45, 72 or 102 hours. After incubations, cultures were examined for growth and riboflavin formation in the same manner as in the previous experiment. The results are given in Table 16.

The number of washings had no effect on growth or riboflavin formation. This would seem to indicate that any factor being carried over 
THE GROWTH AND PIOMTITATION ON THE GLUTAMIC ACID - AROTNTNE - GLYCINE (GAC1Y) MEDIUH TNOCULATID WITH CELIS WASHED A DIFFLRENT NUMBER OF TINES

\begin{tabular}{|c|c|c|c|c|c|c|}
\hline \multirow{3}{*}{$\begin{array}{l}\text { Number of } \\
\text { Washings }\end{array}$} & \multicolumn{6}{|c|}{ Period of Incubation } \\
\hline & \multicolumn{2}{|c|}{45 hrs. } & \multicolumn{2}{|c|}{$72 \mathrm{hrs}$} & \multicolumn{2}{|c|}{$102 \mathrm{hrs}$} \\
\hline & Growth & Pigment & Growth & PIgment & Growth & Plgment \\
\hline 0 & +3 & 0 & +4 & \pm 1 & +5 & +2 \\
\hline 0 & +3 & 0 & +4 & 0 & +5 & +2 \\
\hline 1 & +3 & 0 & +4 & 0 & +5 & +2 \\
\hline 1 & +3 & 0 & +4 & \pm 1 & +5 & +2 \\
\hline 2 & +3 & 0 & +4 & 0 & +5 & +2 \\
\hline 2 & +3 & 0 & +4 & \pm 1 & +5 & +2 \\
\hline 3 & +3 & 0 & +4 & 0 & +5 & +2 \\
\hline 3 & +3 & 0 & $+\overrightarrow{4}$ & 0 & +5 & +2 \\
\hline 4 & +3 & 0 & +4 & 0 & +5 & +2 \\
\hline 4 & +3 & 0 & $+\sqrt{4}$ & 0 & +5 & +2 \\
\hline
\end{tabular}

over by the cells from the yeast extract-peptone agar slants must be elther bound relatively tightly to the cells or contained vithin the cells.

9. The Effect of Miscellaneous N1trogen Sources on Growth and Riboflavin Formation. Several different nitrogen sources were teated to ascertain their effects on the growth and ribollavin formation by $\mathbb{A}$. gossypil. A mediun was prepared for each nitrogen source by adding $0.5 \mathrm{~g}$. of the single nitrogen source to $100 \mathrm{ml}$. of the basal, the nitrogen sources being $\mathrm{NH}_{4} \mathrm{HO}_{3}, \mathrm{KNO}_{3},\left(\mathrm{NH}_{4}\right)_{2} \mathrm{SO}_{4}$, ammonium acetate, anmonium citrate and urea. The results in all the medis showed no growth or rlboflavin formation, Indicating that A. Bossypis probably cannot grow or produce ribonlavin on simple nitrogen sources but aust require more complex organic nitrogen 
sources.

Although the inorganic nitrogen sources ald not support growth or riboflavin formation when used as the only nitrogen source in a medium, it was possible that they might have sane effect when added to a medium containing organic nitrogen sources. In order to test this possibility, a medium was prepared by adding $0.5 \mathrm{~g}$. of peptone and $0.5 \mathrm{~g}$. of $\mathrm{MH}_{4} \mathrm{NO}_{3}$ to $200 \mathrm{ml}$. of the basal. The medium was sterilized and inoculated in the usual manner and incubated on the shaker at $28^{\circ} \mathrm{C}$. After 4 days of incubation the Rlasks showed a good growth of A. Eossypli but very 1ittle riboflavin formation, as apparent from the lack of pigmentation. It was evident that the addition of $\mathrm{NH}_{4} \mathrm{NO}_{3}$ to the medium in the presence of peptone resulted in a decreased synthesis of riboflavin, since the peptone alone had been shown previously to support growth and riboflavin formation.

This effect was studied further with $\mathrm{KMO}_{3}$ and amoniun acetate. A peptone medium was prepared by adding $0.5 \mathrm{~g}$. of peptone to $100 \mathrm{ml}$. of the basal and the reoulting medium was used to prepare two other media, one containing $0.5 \mathrm{~g}$. of $\mathrm{KNO}_{3}$ per $100 \mathrm{ml}$. of the medium and the other containing $0.5 \mathrm{~g}$. of ammonive acetate per $100 \mathrm{ml}$. of the medium. The media were innculated, sterlilzed axd Incubetod in the usual manner and examined visualiy for growth and pigmentation. The growth in both media. was very good; however, in the medium containing the $\mathrm{KrO}_{3}$ there was no appreclablo plgnentation, whereas in the medium containing the amonium acetate there was a nomal yellow pigmentation preaent. From these results it appeared that the nftrate fon, at the concentration used, might act in some way to inhibit the formation of ribonlavin when the lon was 
In the presence of peptone. This fact may be of use in further studies of the ribollavin metabolism of $\mathbb{A}$. gossypil.

10. The Treatment of Peptone with Permutit. It has been shown previously in Experiment number 3 that the more basic couponents of peptone seened to be concerned with ribonavin formation in A. gossypil, rather than the other components. If these basic components could be. removed from the peptone in scme simple manner, then their relationshlp to ribolavin synthesis could be further demonstrated. Since Permutit has been used to remove ammonis in urine analysis, it might also renove the more basic courponents of peptone.

. The experiment was carried out on a solution containing $0.5 \mathrm{~g}$. of peptone dissolved in $50 \mathrm{ml}$. of distilled water. Five grans of vashed Permutit was added to the solution which was stirred for several minutes. The Permutit was renoved by filtration and the filtrate containing the unabsorbed parts of peptone wea made into a medium by adding the other component parts of the basal to the filtrate and diluting it to $100 \mathrm{ml}$. An untreated peptone medive was prepsed by adding 0.5 per cent of peptone to the standard basel. The Permutit treated and untreated media were inoculated with a washed 48 hour cell suspension of 1 . gossypis and Incubated for 4 days at $28^{\circ} \mathrm{C}$. on the shaker. The growth was then measured by obtaining the dry weight of an allquot of cells before extraction of riborlavin and the ribollavin was measured fluorometrically in the usual manner. The results of the experiment are shown in Table 17.

The date show a great contrast between the treated and the untreated peptone medie. The growth in the treated peptone medium was 


\section{TABLE 27}

THE GRONTH AND RIBOFLAVIN FOMUATION ON MEDIA CONEATNINO UNTREATED AND PERMUTIT TSEATED PIPTONE

\begin{tabular}{|c|c|c|c|c|c|c|c|c|}
\hline \multirow[t]{2}{*}{ Nedium } & \multicolumn{4}{|c|}{$\begin{array}{l}\text { Dry Weight Cells } \\
(\mathrm{mg} / 20 \mathrm{ml})\end{array}$} & \multicolumn{4}{|c|}{$\begin{array}{c}\text { Riboflavin } \\
(\mathrm{ug} / \mathrm{ml})\end{array}$} \\
\hline & $I$ & 2 & 3 & Ive. & $I$ & 2 & 3 & Ave. \\
\hline $\begin{array}{l}\text { Untreated } \\
\text { Peptone }\end{array}$ & 78.0 & 79.8 & 92.0 & 83.2 & 47.5 & 67.5 & 110.8 & 75.3 \\
\hline $\begin{array}{l}\text { Permutit } \\
\text { Treated } \\
\text { Peptone }\end{array}$ & 120.0 & 210.4 & 218.2 & 116.2 & 4.8 & 5.1 & 5.3 & 5.1 \\
\hline
\end{tabular}

now approxinately 25 per cent greater than that in the untreated peptone medium which indicated that Permutit did not remove anything from the peptone which wes essential for the growth of the organism. In fact, the treatment of the peptone may have removed something that was inhibitory to the growth of the organism.

The effect on riboflavin formation was even more pronounced than the effect on growth. The average jleld of riboflevin was 5.1 ug. per ml. for the treated peptone medium and $75.3 \mathrm{ug}$. per $\mathrm{ml}$. for the untreated peptone medium or fifteen times as much riboflavin formed in the untreated over the treated media. When Permutit was treated with a $1 \mathrm{M}$ solution of IXH, the absorbed substances from the extraction were freed into the solution. The eluate, from the Permutit, used in the peptone treatment, showed the presence of ninhydrin positive substances when spotted on filter paper and sprayed with the ninhydrin developing reagent. This verifled that something was removed from the peptone when treated with 
Permutit and the factors removed may be concerned in the synthesis of riboflavin. A circular chromatogram of the eluate from the Pernutit showed that only one wide ring was present and this heavy ring had an $R_{f}$ value of $0.30-0.31$ which corresponds vith one of the $R_{f}$ values of the components in the ribollavin stimulating combined fraction found in the colum separation of peptone.

A portion of the Permutit eluate was hydrolyzed with 6 N HCI in a sealed glass tube by autoclaving the tube at 15 pounds stean pressure for 1 hour. A sample of the eluate and hydrolyzed eluate were chromatographed by the two dimensional techriques on Whatman muber 1 sheet fllter paper with the n-butanol-acetic acid-water and pyridine-tertiary anyl alcohol-water solvents. The chromatogram of the unhydrolyzed eluate showed one large ninhydrin positive spot which had $\mathrm{P}_{I}$ values of approxdmately 0.13 and 0.21 , respectively, with the two solvents. The chromatogram of the hydrolysed eluate showed nine distinct gpots. Their Rf values were calculated and the possible amino acids identified by cormparison of the values with those for pure anino acids. The $\mathbb{R}_{\mathfrak{f}}$ values and corresponding possible amino acids are given in Table 18.

To study this absorbed fraction further, a medium was prepared from the regular CA medium by adding $70 \mathrm{mg}$. of L-lysine KCl, $20 \mathrm{mg}$. of I-histidine $\mathrm{HCl}, 15 \mathrm{mg}$. of glycine, $40 \mathrm{mg}$. of DL-threonine, $30 \mathrm{mg}$. of L-proline, $10 \mathrm{mg}$. of L-leuclne and $5 \mathrm{mg}$. of phenglalanine to $100 \mathrm{ml}$. of the medium. These amino acids were selected from those in the above table because in previous experiments all of them gave some indication of being related to riboflavin synthesis. The medium wae adjusted to pll 6.5 with a solution of KOH, sterilized and inoculated vith a 48 hour washed 
TABLE 18

THE Re VALUES AND POSSIBLE ANINO ACIDS PRESENT IN A CHRONA TOCRUPHED, HYDROLYZED PEPRUTIT EXTRACTED TRACTION OF PEPTONE

\begin{tabular}{|c|c|c|}
\hline $\begin{array}{c}\text { Butanol Solvent } \\
R_{f}\end{array}$ & $\begin{array}{c}\text { Pyridine Solvent } \\
\mathrm{R}_{\mathrm{f}}\end{array}$ & $\begin{array}{l}\text { Possible Amino Acid } \\
\text { Composition }\end{array}$ \\
\hline 0.16 & 0.17 & $\begin{array}{l}\text { Lysine } \\
\text { Arginine }\end{array}$ \\
\hline 0.17 & 0.29 & Histidine \\
\hline 0.20 & 0.39 & Serine \\
\hline 0.26 & 0.19 & $\begin{array}{l}\text { Aspartic acid } \\
\text { Glutemlc acid }\end{array}$ \\
\hline 0.24 & 0.27 & gljeine \\
\hline 0.30 & 0.38 & threonine \\
\hline 0.35 & 0.42 & proline \\
\hline 0.61 & 0.59 & valine \\
\hline 0.72 & 0.68 & $\begin{array}{l}\text { leucine } \\
\text { 1soleuc1ne } \\
\text { phenylalanine }\end{array}$ \\
\hline
\end{tabular}

cell suspension. After incubation on the shaker for 4 dars at $28^{\circ} \mathrm{C}$., the flasks were examined vigually for growth and riboflavin formation. This medium gave excellent growth of the organism but ald not show any appreciable riboflavin formation. These results indicate the strong effect due to interrelationshipa of amino acids since under other conditions these amino acids showed an effect on riboflavin synthesis; however, when they were together in these concentrations there was no appreciable effect on the formation of the vitamin. It appears that further study is necessary 
In order to determine an amino acid mediua which will give good gields of riboflavin.

11. The Growth and Ribomavin Synthesis on the Glutemic ActdArginine Kedium with Different Concentrationg of Clycine. Since glycine was one of the arino acids which stimulated the formation of mbollavin In the $\mathrm{GA}$ medium, a series of $\mathrm{GA}$ media vere prepared to determine the effect of different concentrations of glycine on growth and riboflavin formation when the glycine was added to the GA medium. The GA modia were prepared in the same way as that in Experiment number 7 except different amounts of glycine were also included in the medis. The GA mediun without added $\mathrm{g}$ lycine served os a control for the experlment. The media were sterilized and duplicate rlasks inoculated with a 48 hour washed cell auspension of 1 . gossypi1. After incubation for 4 days on the shaker at $28^{\circ} \mathrm{C}$. , the growth was deternalned tarbidimetrically and the riboflavin was determined fuorometrically as in previous experiments. The concentrations of glyeine in the media and the result of the experiment are reported in Table 19.

The addition of different concentrations of glycine had very little apparent effect on growth, as shown by the turbsdity readings for the different rlasks, even though there was a considerable Increase in the total nitrogen in the medis, as compared with the GA control medium. The addition of glycine to the $\mathrm{CA}$ medium resulted in an increased forruation of riboflavin. The increase in riboflavin was rather gradual and reached a maxdmum value of $15.2 \mathrm{ug}$. per $\mathrm{ml}$. when $30.0 \mathrm{mg}$, of glycine wes added to $100 \mathrm{ml}$. of the $\mathrm{CA}$ medium. When $40.0 \mathrm{mg}$. or $50.0 \mathrm{mg}$. of glycine was added to the $G A$ medium, there was no further increase in riboflavin 
THE GROWTH AND RIBOFLAVIN SWNTHESIS OF A. COSSTPII IN GLUTAIC ACID - ARGININE (GA) F̈EDIA WITH ADDED AMPUNTS OF GLYCINE

\begin{tabular}{|c|c|c|c|c|c|c|}
\hline \multirow{2}{*}{$\begin{array}{l}\text { Glycine Added } \\
\text { to OA Nedivm } \\
\text { (mg/100 ml) }\end{array}$} & \multicolumn{3}{|c|}{$\begin{array}{c}\text { Turbidity } \\
\text { (\% Transpittance) }\end{array}$} & \multicolumn{3}{|c|}{$\begin{array}{l}\text { Riboflavin } \\
\text { (ng/mi) }\end{array}$} \\
\hline & 1 & 2 & Ave. & 1 & 2 & Ave. \\
\hline 0 & 9.7 & 9.2 & 9.5 & 0.61 & 0.59 & 0.60 \\
\hline 1.0 & 9.9 & 10.2 & 10.0 & 1.1 & 1.1 & 1.1 \\
\hline 2.5 & 10.2 & 8.5 & 9.3 & 3.4 & 3.4 & 3.4 \\
\hline 5.0 & 21.2 & ע.2 & 12.6 & 3.8 & 3.8 & 3.8 \\
\hline 10.0 & 10.1 & 11.2 & 10.6 & 2.8 & 2.8 & 2.8 \\
\hline 15.0 & 10.9 & 12.1 & 111.4 & 7.5 & 7.5 & 7.5 \\
\hline 20.0 & 10.0 & 9.2 & 9.6 & 11.2 & 10.3 & 10.8 \\
\hline 30.0 & 10.0 & 10.8 & 10.4 & 15.3 & 15.0 & 15.2 \\
\hline 40.0 & 10.0 & 13.8 & 11.9 & 10.6 & 10.0 & 10.3 \\
\hline 50.0 & 11.0 & 12.7 & 21.8 & 12.5 & 12.5 & 12.5 \\
\hline
\end{tabular}

formation which might indicate that a limiting condition had been reached and, as a result, further increases of other substances might be necessary for further conversion of glycine to the internediate in ribolavin gynthesis.

These results indicate a relationship of glycine to ribollavin formation in the $O A$ medium; however, it appears that other substances must be necessary for further riboflavin synthesis in this wedium. This relationship of glyeine to riboflavin formation in A. gossyoil was in agreenent with the results of Plaut (67) who showed that tagged glycine 
was incorporated into the ring portion of the riboflavin molecule.

12. The Effect of Different Concentrations of Peptone on Crowth and Riboflavin Formation in a Olutemic Acid - Arginine - Glycine Medium. The preceeding experiment ahowed that glycine stimulated ribollavin formation in the OA medium but the gleld was considerably less than that which could be obtalned from peptone at approximately the sane nitrogen concentration. If peptone contalned some factor which was responsible for the formation of riboflavin, the addition of peptone to the glutemle acidarginine-glycine (GAGIy) medium should show an increased formation of ribollavin. To test this, the Gally medium vas prepared by adding $20 \mathrm{mg}$. of glycine to $100 \mathrm{ml}$. of the regular $\mathrm{GA}$ medium which has been described previously. The peptone was added to the CACly medium in amounts ranging from $0.001 \mathrm{gg}$. to $100 \mathrm{mg}$. per $200 \mathrm{ml}$. of the medium, duplicate Rlasks being set up for each amount of peptone added, as well as, a duplicate set of Nakks containing the GAGly mediun as a control. The media vere sterilized in the usual manner and 1noculated with a 48 hour washed cell suspension of $\underline{A}$. gossypili. The inoculated flasks were Ineubated on the shaker for 4 days at $28^{\circ} \mathrm{C}$. After Incubation, the nasks were removed and the rearlting growth and riboflavin vere measured using the dry weight of cells and fluorometric aralyais, respectively. The concentrations of the peptone added and the results obtained are presented in Table 20.

The addition of increasing amounts of peptone to the GACly medium resulted in a gractual increase in the growth of the organism, except for the two lower anounts of added peptone where the growth was erratic. The addition of $100 \mathrm{mg}$. Of peptone to the GAGIy medium resulted in the largest Increase in growth, amounting to approxdmately two times that of the GAGIy 
THE GROWTH AND RIBOFLAVIN SWVTHESIS IN A GLUTAMIC ACID ARGININE - GLYCIME (GACIY) MEDIUM CONTATNING

VARIOUS CONCERTTATIONS OF PEPTONE

\begin{tabular}{|c|c|c|c|c|c|c|c|}
\hline \multirow{3}{*}{$\begin{array}{l}\text { Concentration } \\
\text { of Peptone } \\
\text { (ms/100 ml) }\end{array}$} & \multirow{2}{*}{\multicolumn{3}{|c|}{$\begin{array}{l}\text { Dry We1ght Cells } \\
\text { (me/20 ml) }\end{array}$}} & \multicolumn{4}{|c|}{ Riboflavin } \\
\hline & & & & & (iml) & & Tug/ng \\
\hline & 1 & 2 & Ave. & $I$ & 2 & Ave. & $\begin{array}{c}\text { dry } \\
\text { cells) }\end{array}$ \\
\hline $0^{*}$ & 53.6 & 53.8 & 53.7 & 16.0 & 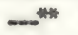 & 16.0 & 6.0 \\
\hline 0.001 & 84.2 & - & 84.2 & 7.5 & - & 7.5 & 1.8 \\
\hline 0.01 & 36.0 & 32.8 & 34.4 & 8.0 & 9.8 & 8.9 & 5.2 \\
\hline 0.10 & 53.2 & $-\infty^{*-1 * *}$ & 53.2 & 10.8 & $\ldots$ & 10.8 & 4.1 \\
\hline 1.00 & 63.0 & 74.6 & 68.8 & 16.0 & 8.6 & 12.3 & 3.5 \\
\hline 5.00 & 85.2 & 73.8 & 79.5 & 5.7 & 5.7 & 5.7 & 1.4 \\
\hline 25.00 & 97.0 & - ב-ב & 97.0 & 5.7 & - & 5.7 & 1.2 \\
\hline 50.00 & 77.4 & 85.4 & 81.4 & 5.7 & 2.8 & 14.3 & 1.0 \\
\hline 100.00 & 97.8 & 104.4 & 101.1 & 2.2 & 2.4 & 2.3 & 0.5 \\
\hline
\end{tabular}

* GAGly control.

* Lost because of breakage.

***: Contandinated Flask.

control medium.

The addition of different concentrations of peptone to the GAGLy control medium d1d demonstrate a marked effect on riboflavin forruation. The GAaly control showed the formation of 16.0 ug. of ribonavin per ml. which was the marimum produced in this experiment. The eddition of peptone to the CAOly medium resulted, in general, in a decreased forration for riboflavin, with the lowest value of 2.3 ug. per ml, being obtained 
In the medium to which $100 \mathrm{mg}$. of peptone had been added per $200 \mathrm{ml}$. of medium. The addition of the 100 mg. of peptone reduced the riboflavin formed to about one-eighth the value of the control. There appears to be an inverse relationship between growth and riboflavin formation, since the increased growth was accompanied by the decreased formation of mboravin. This is especially evident as shown by the amount of riboflavin produced per mg. dry weight of cells which decreased as the anount of peptone was increased. The addition of the peptone to the GAGIy medium might have increased the growth metabolism of the organian, therefore, decreasing the availability of those intermediates necessary for riboflavin formation. The results of this experinent serve to reiterate the importance of the interactions of nitrogen sources in the formation of ribonavin by $\mathbf{A}$. gossypil.

13. The Effect of the Components of the Clutamic Acid - Arginine Gycino Medium on the Synthesis of Ribonlarin in a Peptone Medium. The unexpected inhibition of ribollavin formation by the addition of peptone to the GAOly medium raised the question as to which part of the synthetic medium might be causing the effect, if this were the reason for the effect. This experiment was performed in an effort to obtain some information concerning the effects of the different components of the CAGIy medium on the riboflavin formation in a peptone mediun.

$\Delta$ peptone medium wes prepered by adding $100 \mathrm{mg}$. of peptone to $100 \mathrm{ml}$. of the basal, which was used for the preparation of other media. There were three media used for this experiment and their composition was as follows: Medium number 1, the control, was the peptone medium prepared as just described, Medium number 2 vas the peptone medium to which $0.21 \mathrm{~g}$. 
of glutamic acid and $0.01 \mathrm{~g}$. of arginine $\mathrm{HCl}$ had been added per $100, \mathrm{ml}$, of medium and Nedium number 3 was the peptone medium supplemented with $0.02 \mathrm{~g}$. of glyeine per $100 \mathrm{ml}$. of medium. Duplicate flasks of the media were sterllized and inoculated with a 36 hour washed cell suspension of 1. gossypi1. The inoculated nedia were incubated for 5 days on the shaker. at $28^{\circ} \mathrm{C}$. The growth was examined vieually and the miboflavin determined fuorometrically in the usual menner. The results of the experinent are given in Table 21.

\section{TABLE 21}

THE SWNTHESIS OF RIBOFLAVIN IN A PEPTONE UEDIUM CONTAINING CONPONENTS OF THE OLOTANIC ACID - AROININE - GLYCIME (GAOIY) VIBDIUM

\begin{tabular}{|c|c|c|c|c|}
\hline \multirow{2}{*}{$\begin{array}{c}\text { Amino Acids Added } \\
\text { to Peptone Medium } \\
(\mathrm{g} / 100 \mathrm{ml})\end{array}$} & & \multicolumn{3}{|c|}{$\begin{array}{c}\text { Riboflavin } \\
\text { (ug/mi) }\end{array}$} \\
\hline & & 1 & 2 & Ave. \\
\hline 0 & & 10.3 & 9.4 & 9.9 \\
\hline $\begin{array}{l}\text { I-glutanic acid } \\
\text { Lmarginine } \mathrm{HCl}\end{array}$ & $\begin{array}{l}(0.21) \\
(0.01)\end{array}$ & 0.8 & 0.8 & 0.8 \\
\hline Glyeine & $(0.02)$ & 13.1 & 10.6 & 11.9 \\
\hline
\end{tabular}

Since growth in all the media was very good, the possibility of any Inhibition effects due to the addition of components of the GACly medium was eliminated. The ribollavin formation averaged 9.9 ug. per ml. In the peptone medium which was a reasonable value for the amount of nitrogen present in the mediun. The addition of the glutamic acidarginine components of the CACly medium to the peptone mediun caused the ribcrlarly forssation to be reduced to an average of 0.8 ug. per rl., 
whereas, the addition of glycine alone produced a slight inerease in riboNavin formation as compared to that formed in the peptone medium. These results indicated that the glutanic acid-arginine portion of the Galy medium must have caused the inhibition of riboflavin formation by $A$. gossypili in the peptone medium and that this was probably the effect observed in Table 20 of the preceeding experiment. Van Lanen, et el. (105) reported that dicarboxylic acids and their derivatives interferred with the synthesis of ribolavin by A. gossypif. Under the condition of growth when peptone and glutemic acid are both present in the same medium, glutanic acid may be converted to $\alpha$-ketoglutarlc acld through deamination, and thereby giving a sufficient concentration of the dicarboxylic acid to exert an inhibitory effect on the formation of riboflavin.

14. The Iffect of a Cell Extrect of A. gossypis on Growth and Riboflavin Formation. Since the experiments on serlal transfer (Experiments 13, $1_{4}$ and 15) had indicated the possibility of a factor being carried over with the yeast extract-peptone agar slant cells, an extraction of this type cell was made. The extract was prepared from pigmenting cells of $A$. gossypis which were removed with an inoeulating loop frou several 48 to 72 hour yeast extract-peptone agar slants. The cello were placed in a mortar and ground in a smell amount of distilled water with a mixture of ground glass and sand, in order to break up the celle. The ground mixture was centrifuged and the centrifugate, about $10 \mathrm{ml}$., removed as the cells extract which was stored in the freezing compartant of a refrigerator.

Two media were prepared with the following compositionst Nedium number 1, designated $\mathrm{GA}$, contained $0.210 \mathrm{~g}$. of glutanic acid and $0.010 \mathrm{~g}$. 
of arginine HCl per 100 ml. of the basal and Nedium number 2, designated CAGly, contained $0.020 \mathrm{~g}$. of glycine per $100 \mathrm{ml}$. of the $\mathrm{GA}$ medium. Before sterilization of the GA and GAGly media, $0.1 \mathrm{ml}$. of the A. gossypil cell extract was added to each $20 \mathrm{ml}$. of the different media in Erlenmeyer Nasks. After sterilization, duplicate Rasks of the media vere Inoculated with a 36 hour washed cell suspension of A. gossypli and incubated on the shaker for 4 days at $28^{\circ} \mathrm{C}$.

At the completion of the incubation perlod growth was observed and ribomavin determined fuorometrically. Growth was very good in all but one flask which showed no growth at all, this Plask being one containing the OA medium plus the cell extract. The results of the fluorom metric deterninations of riboflevin are shown in Table 22.

\section{TABLE 22}

THE SWNTHESIS OF RIBOFLAVIN BY A. GOSSTPII IN GLUTAMIC ACID ARGIIIR (GA) AND CLUTAVIC ACID- - ARGININT - GLYCINE (GAG1y) MEDTA CONTATNING 0.1 MILLILITER OF CBLL BXTRACT

\begin{tabular}{cccc}
\hline Medium & \multicolumn{3}{c}{$\begin{array}{c}\text { Riboslavin } \\
\text { (ug/mi) }\end{array}$} \\
\cline { 2 - 4 } GA & 2.7 & No growth & 2.7 \\
GACly & 21.8 & 26.9 & 24.3 \\
\hline
\end{tabular}

The addition of the cell extract to the a mediun resulted in a riboflavin Jield which was only slightly greater than that which has been reported for the $O A$ medium in other experiments. This increased yield mey have been due to the amall anount of riboflevin added with the $0.1 \mathrm{ml}$. 
of the cell extract which did contain a small anount of the vitamin. The effect of the cell extract was very evident in the GAOLy medium where a rboflavin Fleld of $24.3 \mathrm{ug}$. per wl. of mediun was reported. This was approxdmately double that which was normally produced in this mediven vithout the presence of added extract and therefore indlcated the presence of some factor in the extract wich stimulated the formation of ribonavin. In observations of the progrees of growth in this experiment, it was noted that a perceptible anount of pigmentation had formed in Mediun number 2 after only 12 hours of incubation which was several hours sooner than previously observed. Since the cell extract was added to the medium before sterlisation, the stimalation factor must be some heat stable compound or compounds, contalned in the cell extract or resulting from the autoclaving of the cell extract, which accounts for the stimulation of riboflavin formation in the presence of glyeine. Autoclaving would also eliminate the probability that an ensyme or enzyme system in the cell extract was stimulating the synthesis of the viteutin. The relationship of glycine to ribollavin synthesis was more flrmly eatablished as a revult of these findings since the Increased riboflavin formation was noted only in the GACly mediun.

\section{The Effect of Chromatographic Fractiong of an A. gossyoli}

Ce11 Extract on Ribollavin Formation. The previous experiment had shown that the extract of A. gossypil cells stimulated the formation of riboflavin in the CA medium with added glycine. In an effort to determin if the whole extract or only part of the extract was reaponsible for the increased Mboflavin formation, the extract was chromatographed on f1lter paper strips and Iractions were tested. 
The extract was chronatographed on strips of Whatman number 1 f1lter paper with the n-butanol-acetic acid-water solvent mixture as the resolving system. After $0.05 \mathrm{ml}$. of the cell extract had been applied to each of three fliter paper strips and dried, the strips were placed in the solvent containers and chromatographed for approximately 6 hours. At this time, the strips were removed from the solvent and allowed to air dry. Two of the strips were sprayed with indicator reagents and the third was scanned with ultraviolet light. Strip number 1 was sprayed with a ninhydrin solution to test for the presence of ninhydrin positive components, such as, anino acids, peptides and some protelns. Strip number 2 was developed with a phenol red indicator solution which would locate some of the basic componente since the indicator turns red at pH values over 8.5. Strip number 3 was examined under viltravlolet light to locate any Iuorescent spots, especially riboflavin which gives a strong yellow Nuorescence. Strip mumber 3 was also used in the preparation of apecial media for determining the effects of the substances (on riboflavin formation) located at the different spots as shown by the developing agents on strips 1, 2 and 3. The results of the chromatographic excanination of the strips, together with the fractions to be incorporated into the media, are shown in Table 23.

The $G A$ and CAGly media were prepared from the basal as described in the preceeding experiment. No cell extract was added to the GA medfum or one flask of the ChGly mediun; however, $0.05 \mathrm{ml}$. of the whole extract was added to one flask of the GAGly medium, thus giving three controls for the experiment. Since only one chromatographic strip was used in this experiment, only one Plask was used for each fraction to be tested. The 
TABLE 23

THE CHROMATOGRAPHIC COMPOSITION OF AN $\wedge$. GOSSIPII CELL EXTRACT PEOM A BUTANOL - ACEIIC ACID - WATER SOLVENT SEPARATIOH

\begin{tabular}{|c|c|c|c|}
\hline Fraction Number & Developing Agent & $R_{P}$ Values & Color Forned \\
\hline$I$ (origin) & $m$ & 0 & None \\
\hline 2 & Ninhydrin & 0.23 & Light orange \\
\hline 3 & Ninhydrin & 0.31 & Purple \\
\hline 5 & Ninhydrin & 0.58 & P1nk \\
\hline 6 & Ninhydrin & 0.75 & Light pink \\
\hline 3 & Phenol Red & 0.28 & Red \\
\hline 3 & WV light & 0.30 & Blue fluor. \\
\hline 4 & UV 11ght & $0.45^{*}$ & Yellow fluor. \\
\hline $7^{* *}($ top $)$ & $-m$ & $-\infty$ & - \\
\hline
\end{tabular}

\section{* Riborlavin.}

* Portion of strip Irom last spot to solvent front.

chromatographic fractions, mmbered according to Table 23, were cut from strip number 3 and placed Into separate Rlasks of the CACIy nedium. These redia, together with the GA and GAGIy controls, were sterilized and the sterile media inoculated with a 4 h hour old washed cell suspension of A. gossypil. After an incubation period of 108 hours on the shaker at $28^{\circ} \mathrm{C}$., the Iuorometric determination of the ribollavin was made. The results are shown in Table 24 .

Since rilter paper had been Introchuced into the Rasks with the chromatographic fractions, the dry weight of cells was not determined, 
TABLS 24

THE ERTECT OF CHRONATOGRAPHIC CEIL EXTRACT FRACTIONS ON RIBOFLAVIN SWTHESIS BY A. GOSSYPII IN A GLUTAMIC ACID AROININE- - GLYCINE (GAOIY) MEDIUM

\begin{tabular}{|c|c|c|c|}
\hline $\begin{array}{l}\text { Mediun } \\
\text { Number }\end{array}$ & Principel Mediun & $\begin{array}{c}\text { Added } \\
\text { Extract Fraction }\end{array}$ & $\begin{array}{c}\text { Riboflavin } \\
(u g / m I)\end{array}$ \\
\hline 1 & $G A^{*}$ & - & 0.6 \\
\hline 2 & GACly" & - & 4.3 \\
\hline 3 & $\begin{array}{l}\text { GAGIy plus } \\
0.05 \mathrm{ml} \text {. extract* }\end{array}$ & - & 19.4 \\
\hline 4 & GAGIJ & $I$ & 16.9 \\
\hline 5 & GAGIY & 2 & 5.3 \\
\hline 6 & GAGIy & 3 & 3.8 \\
\hline 7 & GAGIy & 4 & 2.5 \\
\hline 8 & GACly & 5 & 4.7 \\
\hline 9 & GAGIy & 6 & 2.8 \\
\hline 10 & GACIY & 7 & 4.1 \\
\hline
\end{tabular}

* Control redia.

however, observations of growth Indicated that it was excellent in all of the medis. The routine daily examination of the progress of the experiment shoved that pigmentation had appeared in Media 3 and 4 after 36 hours of Incubation. As would be expected, the ribollavin formed in the GA medium was rather amall, while that formed in the AAGly medium, although less than had previously been reported, was noticeably greater than the GA medium control. The stimulation of mboflavin fortiation was again apparent when only $0.05 \mathrm{ml}$. of the whole cell extract waa added to the 


\section{2}

GAGIy mediun before sterilization. An examination of the results when the chromatographic fractions were added to the GAGIJ medium showed that Fraction number 1 stimulated riboflavin formation to approximately the same extent as the whole cell extract. This was unexpected since $1 t$ was felt that the stimulation would probably come from ninhydrin positive portions of the cell extract. Since only $0.05 \mathrm{ml}$. of the cell extract was applied to the origin of the paper strip, the amount of substances remaining at the point of application after the finish of the chromatogran must have been very gmall because the density of the ninhydrin color developed on the spots would indicate a rether heavy concentration of substances, especially at the $R_{f}$ values of 0.31 and 0.58 . Tractions numbered 4 and 6 gave some sllght indication of being inhibitory to riboIevin formation in the GAGly nedium. The remainder of the fractions seemed to shov IIttle effect on riboflavin synthesis. Fraction number 1 may have contalned some of the larger molecular cell components, such as, proteins, nucleotides, etc., which would shov little, if any, migration in the n-butanol-acetic acid-water solvent system.

16. A Further Study of the Effect of Cell Extracts of A. gossypil on Growth and Riborlavin Formation. The date presented in the two preceeding experiments, showed that the extract of 1 . gossroil cells from geast extract-peptone agar slants stimulated the formation of riborlavin In the presence of glycine. Whether this sane stimulatory effect could be shown with extracts from shaker cells grown on the yeast extractpeptone medium, remained to be demonstrated. A large flask was set up as a fernenter in order to grow a large number of ㅅ․ gosssoli under aerated conditions. Three 11ters of mediun were prepared by adding $1.5 \mathrm{~g}$. of 
Difco-peptone, $1.5 \mathrm{~g}$. of Difco-yeast extract and $6.0 \mathrm{~g}$. of glucose to 3 liters of distilled water. The sterilized mediun was inoculated with a 48 hour old cell auspension of $A$. gossypli and Incubated at room temperature with continuous aeration by a stream of sterile diffused air.

After 84 hours of growth, a portion of the medium was removed and the cells filtered off to give $18.4 \mathrm{~g}$. of wet cells. These cells were ground In a small anount of distilled water with sand and powdered glass to disrupt the cells and the resulting extract of the cells was obtained by centrifugation. This extrect will be referred to as the 84 hour aqueous cell extract.

The remainder of the medium was removed after 132 hours and the cells removed by filtration to yleld $58.8 \mathrm{~g}$. of wet cells. A $15 \mathrm{~g}$. portion of the cells wes dried with cold acetone to yleld $2.8 \mathrm{~g}$. of acetone dried cells and an acetone extract of the cells. The remaining $43.8 \mathrm{~g}$. of cells was extracted in the same manner $2 \mathrm{~s}$ the 84 hour cells to give a 132 hour aqueous cell extract. The aqueous extracts of the different age cells were made in order to deternine at which phase of growth the stimulatory factor or lactors were most predominate. $\mathbf{1 1 1}$ extracts were stored in the refrigerator when not in use. A 20 ml. portion of the 132 hour aqueous cell extract was lyophilized to give $0.17 \mathrm{~g}$. of drled sollds or $8.5 \mathrm{mg}$. per ml. of extract. The GA and GAGly media for testing the extracts were prepared from the basal according to previous procedures. The other media for the experiment were prepared by the addition of the cell extracts and dried cells, to the GAGly mediusn. After the addition of the cell extracts and dried cells, the media vere sterilired, inoculated with a 24 hour old washed cell suspension of 1 . gossvopi 
84

and incubated on the shaker for 4 days at $28^{\circ} \mathrm{C}$. The results of the ory weight of cells and the fluorometric riboflavin deterninations are shown in Table 25. In addition, the riboflevin content of each of the added extracts was determined and the average yields corrected for the ribonavin added initially, although much of the riboflavin would have been destroyed in autoclaving the media at a near neutral pH.

\section{TABLE 25}

THE GROVTH AND RIBOFLAVIN FORMATION IN A GLUTAMIC ACID - ARGININE GLYCINE VEDIUY WITH ADDED CELL EXTRACTS AND ACETONE DRIED CELLS

\begin{tabular}{|c|c|c|c|c|c|c|c|}
\hline \multirow[t]{2}{*}{ Yedium Used } & \multirow[t]{2}{*}{$\begin{array}{l}\text { Component } \\
\text { Added/20 ml. }\end{array}$} & \multicolumn{3}{|c|}{$\begin{array}{l}\text { Dry Weight Cells } \\
(\mathrm{mg} / 20 \mathrm{ml})\end{array}$} & \multicolumn{3}{|c|}{$\begin{array}{c}\text { Riborlavin } \\
\text { (ug/ml) }\end{array}$} \\
\hline & & 1 & 2 & Ave. & 1 & 2 & Ave. \\
\hline $\mathrm{CA}^{*} *$ & - & 46.4 & 91.6 & 69.0 & 1.1 & 3.7 & 2.4 \\
\hline 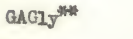 & $-\infty$ & 50.4 & 72.8 & 61.6 & 10.7 & 16.2 & 13.5 \\
\hline GAGIy & $\begin{array}{l}0.1 \text { ml. of } 84 \\
\text { hr. extract }\end{array}$ & 66.4 & 63.6 & 65.0 & 16.5 & 10.0 & $\begin{array}{l}13.1 \\
12.5^{*}\end{array}$ \\
\hline GAGIy & $\begin{array}{l}0.1 \text { ml. of } 132 \\
\mathrm{hr} \text { extrect }\end{array}$ & 50.8 & 44.8 & 47.8 & 38.1 & 44.3 & $\begin{array}{l}47.2 \\
39.2^{*}\end{array}$ \\
\hline GAGIy & $\begin{array}{c}0.1 \mathrm{ml} \text {. acetone } \\
\text { extract }\end{array}$ & 44.2 & 35.4 & 39.8 & 5.5 & 10.5 & $\begin{array}{l}8.0 \\
6.4^{*}\end{array}$ \\
\hline CAOIy & $\begin{array}{l}1.0 \text { mg. acetone } \\
\text { dried cells }\end{array}$ & 76.5 & 62.4 & 69.0 & 5.5 & 11.7 & 8.5 \\
\hline
\end{tabular}

- Corrected averages for riboflavin present in the extracts. * Control media

The results of this experiment verified the previous findings concerning the stimulation of riboflavin synthesis by aqueous extracts of 1 . gossyoil cells and showed that cells grown on a liquid yeast extract-peptone 
medium could procuce the riboflavin stimulating factor. The date showed that the stimulation factor was present only in the 132 hour squeous cell extract which may indicate that it wes formed in the older cells after appreciable riboflavin had been produced. This does not eliminate the posaibility that it could be in the 84 hour aqueous cell extract but if there, the concentration must be less than that which could be demonstrated under the conditions employed. The acetone cell extract and the acetone dried cells apparently did not contein the stirulation factor but rather appeared to contain factors which were inhibitory to the synthesis of Fboflevin in the GACly medium. Although the 132 hour aqueous cell extrect increased the formation of riboflevin, it prociuced a decressed growth of the organism, again showing the inverse relationship between growth and riboflevin formation.

\section{The Colorimetric Analysis of PHboflavin. Since the Iuoro-} metric method reguired a considerable amount of time, it seemed desirable to make an effort to develop a colorimetric assay method to rechuce the time necessary to make an anelysis of the riboflevin produced in a set of experimental media. On this besis some of the accuracy of the Inorometric determinations could be sacriflced in order to gain speed through the colorimetric detemination. A colorimetric method would be especially suited to these studies since the Mboflavin produced by cells in Itquid media was comparatively free from interferring substances. The use of a colorimetric method for the assay of riboflavin had been reported by $\mathrm{Yan}_{\mathrm{a}}$ but no details were given for the procedure. To test the colorimetric method a standard curve was prepared, different sise allquoto of a ground coll extract were assayed and the recoveries of riboflavin added to 
allquots were checked.

An Evelyn colorimeter, which was fltted with a 420 millimicron I1ter, was standardised at 100 per cent transalttance with a distilled water - dithionite solution which contained approrimately $30 \mathrm{mg}$. sodium dthionite per $10 \mathrm{ml}$. of distilled vater. An alr blank was then recorded and the instrument adjusted to this blank throughout the remainder of any test determinations. The riborlavin samples or standard soIutions of 11 to $12 \mathrm{ml}$. volume were added to callbrated colorimeter tubes and the tubes inserted into the colorimeter. The per cent transmisaion of the sample was read to the nearest 0.25 per cent transittance unit and recorded as the sample reading. After the sample was read, approxtmately $30 \mathrm{mg}$. of granular sodiun dithionite was added to the tube, the solution mixed thoroughly and the mixed solution allowed to stand for 30 to 60 seconds. While one tube was standing, another tube in the assay was read and treated in a similar manner, thus no time was lost in waiting for reduction of the ribollevin. After reduction, the dithionite treated sample was also read on the galvanometer scale to the nearest 0.25 per cent transmittance unit and recorded as the correction reading. The sample and correction readings were then converted to absorbance values and the correction subtracted from the sample to give the corrected absorbance value produced by the ribonlavin in the sample. The ribollavin in the sample was determined from a stendard curve which related the absorbance value to known concentrations of riboflavin. AII riboflavin deterwinations that were accomplished colorimetrically in succeeding experiments followed the above procecture. The data in Table 26 was obtained from a colorimetric analysis of a series of standerd 
riboflavin solutions by the above procechure. The data are plotted as a standard curve in Figure 4.

\section{TABLE 26}

ABSORBANCE VALUES FOR KNOWN RIBOFLAVIN SOLUTIONS

\begin{tabular}{|c|c|c|c|c|c|}
\hline \multirow{2}{*}{$\begin{array}{l}\text { Riboflavin } \\
\text { (ug/mi) }\end{array}$} & \multicolumn{2}{|c|}{ Per Cent Transant ttance } & \multicolumn{3}{|c|}{ Absorbance } \\
\hline & Sample & Correction & Sample & Correction & $\begin{array}{l}\text { Corrected } \\
\text { Value }\end{array}$ \\
\hline 0 & - & 100 & $-\cdots$ & $-\cdots$ & 0 \\
\hline 5 & 58.75 & 87.00 & 0.2310 & 0.0605 & 0.171 \\
\hline 10 & 34.75 & 78.75 & 0.459 & 0.104 & 0.355 \\
\hline 15 & 21.00 & 70.00 & 0.678 & 0.155 & 0.523 \\
\hline 20 & 13.75 & 62.75 & 0.862 & 0.202 & 0.660 \\
\hline 25 & 9.25 & 55.75 & 1.034 & 0.254 & 0.780 \\
\hline
\end{tabular}

An examination of Figure 4 show a linear relationship between absorbance and rboflavin concentrations up to 15 ug. per ml., beyond which the curve falls off slightly. However, the relationships are sufficiently linear throughout the curve to allow for a reasonable estimate of the riboflavin concentration.

In order to test this method further, the ribonlavin content of a cell extract, obtained by grinding cells of A. gossypil in a small amount of distilled vater with ground glass and sand, was determined using different aliquots of the cell extract. The aliguots of the cell extrect were tested to check the reprocucibility of the wothod in the presence of increasing concentrations of interferring substances which 
FICURE h

A STAMARO CUEV FOR TAE COLORTIETRIC ANALTSIS of RLBOFLAVIN 
89

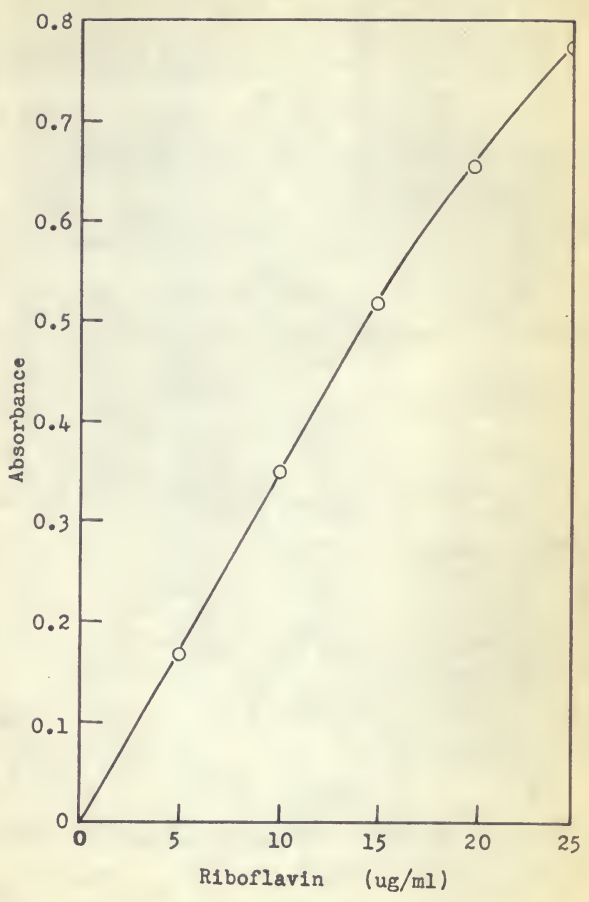


were introduced by the addition of the aliquots of the cell extract. Four unknom samples vere prepared, by adding $0.1,0.3,0.5$ and $1.0 \mathrm{ml}$. of the cell extract to approximately $15 \mathrm{ml}$. of distilled water, and autoclaved in the presence of sodium acetate buffer, as prevlously described, In order to solubilize any bound riboflavin in the cell extract. After autoclaving, the samples were diluted to $25 \mathrm{ml}$. with distilled water before being tested.

A second set of four samples was prepared as just described, except $1 \mathrm{ml}$. of atandard riboflavin solution, containing 25 ug. of riboPlevin per ml., was added to each aliquot sample of the cell extract before autoclaving. This second set of samples was usod to test the method for recoveries of known mounts of mboflavin which were added to the unknovn samples. The resurts for the deterninations are given in Table 27.

The data show good agreement between different allquots of the unknown cell extriact and adequate recoveries of added riboflavin. When the values for the riboflavin content of the original cell extract were averaged, a value of 34.4 ug. of rlboflavin per $\mathrm{ml}$. was obtalned.

Twenty days prior to the colorimetric deterninations on the cell extract, this same extract had been assayed fluorometrically and found to contain $40.5 \mathrm{ug}$. of ribollavin per mil. A comparison of these two values Indicates the colorimetric method gave results about $\mathcal{U}_{4}$ per cent below the fluorometric method. Considering the storage perlod of 20 days in the refrigerator and the fact that some ribollavin was destroyed during storage, the colorimetric assay of the cell extract was in satisfactory agreement with the fluorametric determination, at least for maleing 
娄

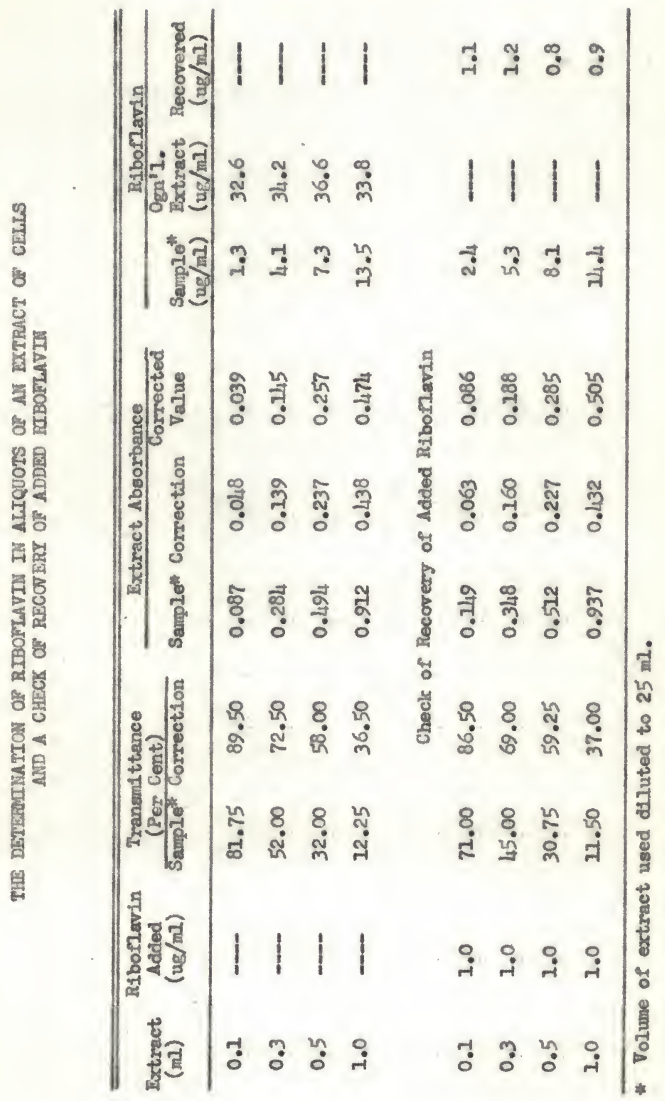


approxdmate assays. The rearlts of the assay above Indicate that the colorimetric determination of riboflavin is feasible by this method, eøpecially where approxdmate measurements are of interest rather than small accurate quantitative determinations. It is belleved that the method could be reflned to a point where It courd be used as a more quantitative method of assay for ribollavin in culture media.

\section{The Effect of Glycine, L-serine and DL-threonine on Growth} and Riborlavin Synthesis when Added to Different Synthetic Media. Giycine, when added to the synthetic glutanic acld-arginine medium, has been shown to be effective in stimulating the formation of riboflavin by $\mathbf{A}$. gossypif (Experiment number 9). The interrelationships of glycine and serine have been reported in the netabolisas of milcroorganisms, therefore, the subatitution of I-serine for glycine might be expected to stimulate riboIlevin formation also. DL-threonine vas used because of its structural similarity to serine and the slight effect on mboflavin synthesis it had previously shown.

The media were prepared from the basal as follows: the glutaric acid-arginine $(\mathrm{GA})$ mediun, $0.210 \mathrm{~g}$. of Lmglutanic acld and $0.010 \mathrm{~g}$. of L-arginine HCI per $100 \mathrm{ml}$. of basal, the aspartic acld-arginine (AR) medium, $0.210 \mathrm{~g}$. of I-aspartic acld and $0.010 \mathrm{~g}$. of L-arglnine HCI per $100 \mathrm{ml}$. of basel, and the asparagine-arginine (Asph) medium, $0.210 \mathrm{~g}$. of asparagine and $0.010 \mathrm{~g}$. of Lmarginine $\mathrm{HCl}$ per $100 \mathrm{ml}$. of basal. The other media were prepared by the addstion of $20.0 \mathrm{mg}$. of glycine, $28.0 \mathrm{mg}$. of L-serine or $63.5 \mathrm{mg}$. of DL-threonine to each of the $\mathrm{CA}, \mathrm{MA}$ and $\mathrm{AgpA}$ medie, the amino aclis being added on the basie of the same L-alpha amino acid nitrogen content. The media vere adjusted to pll 6.5 with $\mathrm{NaOH}_{\text {and }}$ sterillized in 
the usual manner. After sterliliation duplicate flasks of each media wero inoculated with a 36 hour washed cell suspension and incubated for 4 deys at $28^{\circ} \mathrm{C}$. on the shaker. The dry weights of cells and colorimetric mibollavin deterninations on the different media were made; these values are show in Table 28.

The growth was approxdmately the same in the case of the OA and AA medie without added amino aclds but the jlelds of riboliavin were very smoll. The fact that the vitamin synthesis in the AA medium was twice that in the $O A$ modium, may or may not be signiflcant. However, in the Asph medium without added amino acids appreciable riborlavin was synthesized although there was decreased growth of the organism. It has been observed that there was usually less growth in a medium conpared with the control, when riboflavin was produced. When glycine was added at a concentration of $20 \mathrm{mg}$. per $100 \mathrm{ml}$. to each of the three medis, a noticeable increase in the riboflavin formed was observed, especially in the $\mathrm{MA}$ and $\mathrm{Asph}$ media. This would further substantiate the relationship of glycine to riboflavin synthesis with aspartic acid being probably more closely related to the synthesis than glutanic acid. The results with asparagine would seem to agree with this, since asparagine is known to be metabolically related to espartic acid. The increase in riboflavin synthesis shown by asparagine without glyclne may be due, in part at leagt, to the amide nitrogen which is present. Again in the $O A$ and $M$ media, there was decreesed growth when appreclable ribollavin was formed. The subetitution of L-serine or DL-threonine for glycine failed to stimulate vitamin synthesis to the same extent as the glycine. This may indicate that serine and threonine are not as directly involved in ribollavin 
TABLE 28

THE EMFECT OF GLYCINE, L-SERTYE OR DLMTHREONINE ON GROATM AND RIBOFLAVTN SWNTHESIS II GLUTANIC ACID - AROININE, (GA) ASPARTIC ACID - ARGININE (AA) AND ASPARAGINE - ARGININE (AפgA) MEDIA

\begin{tabular}{|c|c|c|c|c|c|c|c|}
\hline \multirow[t]{2}{*}{ Medium } & \multirow{2}{*}{$\begin{array}{l}\text { Amino Acid } \\
\text { Added }\end{array}$} & \multicolumn{3}{|c|}{$\begin{array}{l}\text { Dry Woight Colls } \\
(\mathrm{mg} / 20 \mathrm{ml})\end{array}$} & \multicolumn{3}{|c|}{$\begin{array}{c}\text { Riborlavin } \\
(\mathrm{ge} / \mathrm{ml})\end{array}$} \\
\hline & & 1 & 2 & Ave. & 1 & 2 & Ave. \\
\hline $\mathrm{OA}$ & None & 113.6 & 99.6 & 106.6 & 1.3 & 1.0 & 1.2 \\
\hline GA & Glycine & 97.6 & 96.0 & 96.8 & 10.5 & 16.0 & 13.3 \\
\hline CA & L-serine & 102.2 & 91.6 & 96.9 & 2.5 & 0.5 & 1.5 \\
\hline GA & DL-threonine & 126.4 & 123.6 & 125.0 & 2.8 & 2.0 & 2.4 \\
\hline$M$ & Uone & 109.6 & 104.8 & 107.2 & 2.8 & 2.0 & 2.4 \\
\hline$M$ & Oljeine & 89.8 & 80.2 & 85.0 & 20.2 & 28.8 & 24.5 \\
\hline AA & L-serine & 103.8 & 99.2 & 101.5 & 4.8 & 4.3 & 4.6 \\
\hline $\mathbf{M}$ & DL-threonine & 136.8 & 83.4 & 110.1 & 4.3 & 2.8 & 3.6 \\
\hline Aspd & None & 57.8 & 67.0 & 62.4 & 7.8 & 12.2 & 10.0 \\
\hline A врА & Glycine & 73.4 & $-m^{*}$ & 73.4 & 30.5 & - $^{*}$ & 30.5 \\
\hline Aspa & L-serine & 91.2 & 65.6 & 78.4 & 17.5 & 10.5 & It:0 \\
\hline Aspal & DL-threonine & 66.6 & Q4.8 & 65.7 & 9.5 & 9.5 & 9.5 \\
\hline
\end{tabular}

- Contaninated rlask.

synthesis or it may be due to the fact that under the conditions of the experiment they were not utilized as readily as glycine. If glycine is required for riboflavin formation, the rate of 1ts formation may be a factor; therefore, serine might not stimulate the formation of ribonavin, even though it is thought that glycine is dexived from serine in many microorganisms, because the glycine night not be formed fast enough. 
Serine and threonine have been reported by Goodvin and Pendlington to be related to riboflavin synthesis in E. eshbyil, whereas, glycine had no effect. The data from this experiment would indicato that the reverse may be the case with A. gossyp11.

19. The Iffect of L-histidine HCI on Growth and Riboflavin Formation in Glutardc Ac1d-Arginine and Glutamic Acid-Arginine-Clycine Media. Yaw had reported that histidine was effective in atimulating mboflavin synthesis in E. ashbyis but the addition of histidine to experinental modia in previous experiments of this study failed to show any appreciable effect on riboflevin formation with A. gossmpil. Since oniy one concentration of histidine had been used in the previous experiment, the effect of histidine might not have been apparent; therefore, tests were performed using different concentrations of histidine in the fiA medium and the $\mathrm{GA}$ mediun with glycine (GACIy) of the preceeding experiment. The GAOIy medium contained $20 \mathrm{mg}$. of glycine per $100 \mathrm{ml}$. of the $\mathrm{GA}$ medium. In the first of two tests, the Inoculum was prepared fron a 36 hour washed cell suspension of A. gossmpif which was added to the sterile media and incubated on the shaker for 4 days at $28^{\circ} \mathrm{C}$. After incubation the dry weight of cells and colorimetric riboflavin deterilinations were made. These values and the mounts of histidine added are reported in Table 29.

The lower concentrations of hidtidine showed a stimulation of growth in both media and an inhibition on riboflavin synthesis in the GAGly medium. At higher concentrations of histidine there was a decreased growth of the organian. Histidine may have some effect on ribollavin syntheris in the GA medium especially at high concentrations where a slight stinulation of synthesis was shown on the basis of riboflavin per 


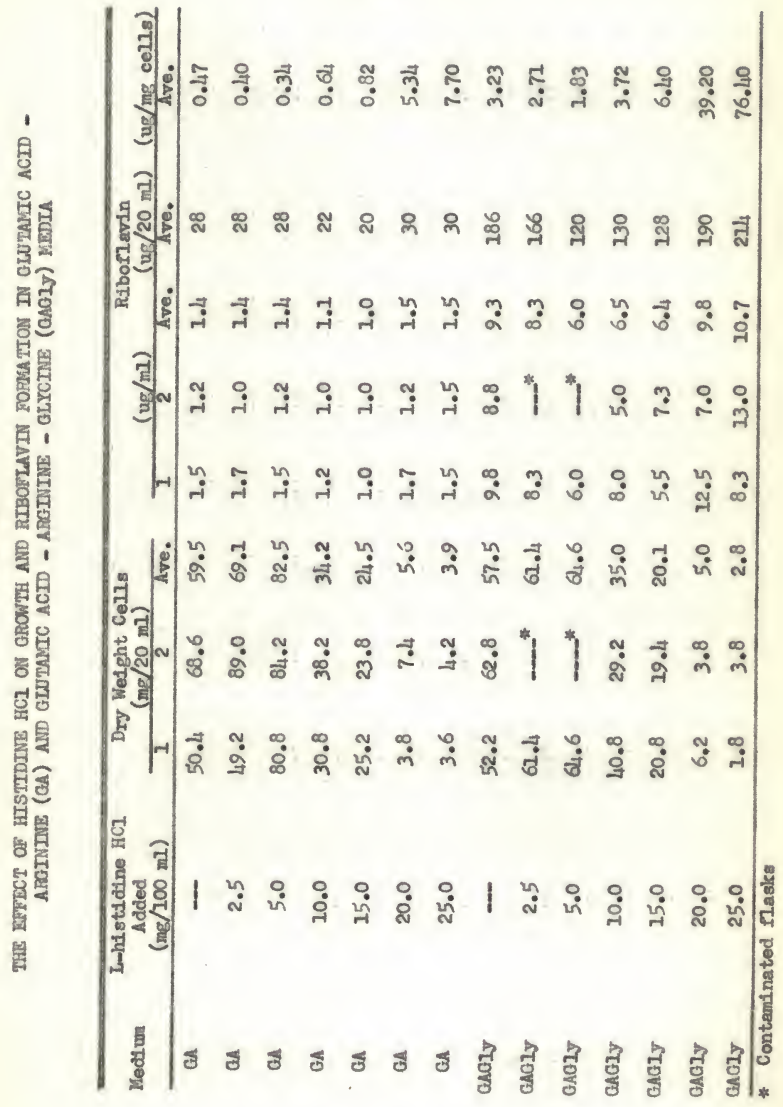


unit dry weight of cells. The effect was also shown at higher concentrations of histidine in the GAGIy medium. The data geen to indicate that there may be two conditions under which riboflavin was aystheaized, namely, synthesis after cells had reached maximum growth and synthesis by histidine Inhibited cells which show only negligible growth. With the lower histidine concentrations, there appeared to be an increased growth accompanied by ribolavin synthesis. It has been shown previously that ribollavin synthesis under conditions of rapid growth occured efter cells had reached mexdmun growth, that is to say, in this experiment riboflavin was synthesized by a relatively large number of cells for a relatively short period of time with the lower hlstidine concentrations. $A_{s}$ the concentration of Mistidine was increased, inhibition of growth occured and less ribomavin was formed by the decreased number of cells that had reached the maxdmum growth phase. At the higher concentration of hiatidine, growth was inh1bited further; however, appreciable riboRavin was synthesized by a relatively amall muber of inhibited cells during the entire incubation period. It has been noted that pigmentation appeared earlier in the media containing the higher concentration of histidine. At the histidine concentration of $25 \mathrm{ag}$. per $100 \mathrm{ml}$., the growth was inhibited in the CAGly mediun to the extent of one-twentieth of the control but the synthesis of the riboflevin was not reterded, as might be expected. The high synthetic rate of the inhibited cells is shown by the ratio of ribollavin synthesized to the dry weight of cells. The other test concerning the ef fect of histidine on growth and riborlavin formation was performed in the same way as the first test, using the same GACly mediun as just described; however, higher concentrations 
of histidine vere used to confir the Inhibition by histldine and to observe any other effects of the higher concentrations, Control media of $\mathrm{GA}$ and CAOIy without histidine were also included. In this test, a 28 hour washed cell suspension was inoculated Into duplicate rlasks of the media and the inoculated rlaeks incubated for 4 days at $28^{\circ} \mathrm{C}$. on the shaker. The amounts of added histidine, the dry weight of cells and the colorimetric deterninations of ribollavin are shown in Table 30.

The results indicate an even stronger inhibition on growth by hlgher concentrations of I-histidine HCl. At concentretions of histidine greater than $30 \mathrm{mg}$. per $100 \mathrm{ml}$. of medium, there seems to be leas total ribolavin aynthesis but this may not be signiflcant. A concentration of $40 \mathrm{mg}$. per $\mathrm{ml}$. seems to be about the maximun concentration necessary, since $50 \mathrm{mg}$. per $100 \mathrm{ml}$. showed only a amell difference in effect on growth or riboflavin formation over the $40 \mathrm{mg}$. concentration. However, there was a steady increase in the amount of riboflavin produced per ng. dry weight of cells, Indicating the sane high rate, if not higher, of riboflavin biosynthesis in the small maber of inhibited cells. Since Inhibition of growth can be shown without stopping' riboflavin synthesis, this effect mey provide a means of separating the growth and riboflavin synthesizing metabolisms of $\underline{\mathbf{A}}$. gossypli.

20. The Effect of Initial pll of the Nedium on Growth and Riboflavin Formation in the Glutemic Ac1d-Arginine Medium and the Glutamic Ac1dArginine-Glycine-Histidine Vedium. The inhibition of the growth of $\mathbf{A}$. gossypis by histidine in the glutamic acid-arginine (GA) and glutamic acld-arginine-glycine (CAGIy) media without accompanying inhibition of ribollavin synthesis, presented a very interesting problen since no 
99

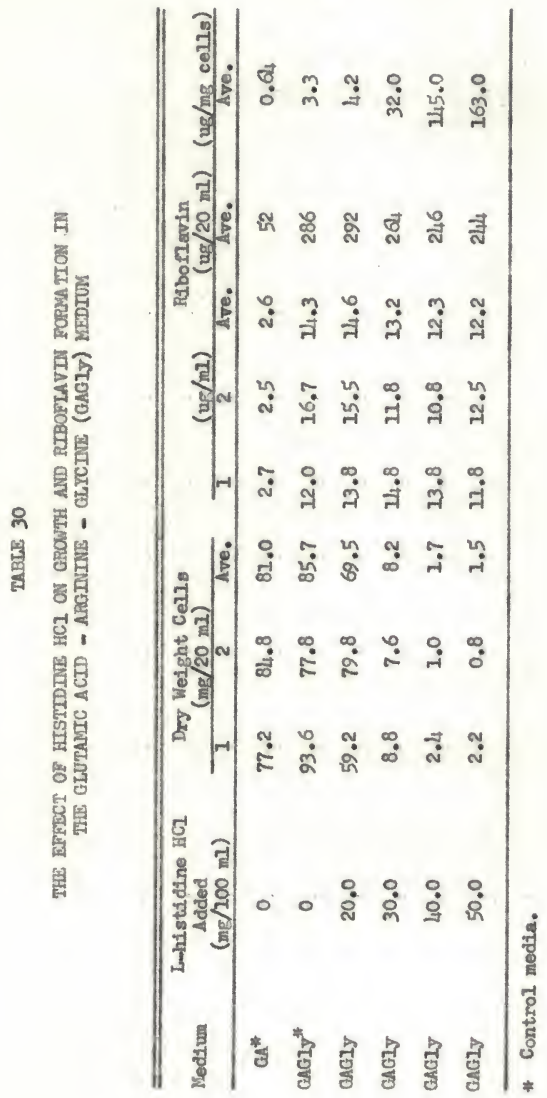


report of this inhibition effect had been noted in the ilterature. Since many inhibitions are a function of the pll at wich they occur, the effect of different initial pll values, on the histiaine inhibition effect, together with growth and rlboflavin formation, were studied. The effect of pll on growth and riboflavin was studied in the CA mediur; however, the histidine inhibition, as affected by pH, was studied only in the GAGI mediun. The GA and CAGIJ media were prepared in the experiment as preVlously described. The glutamic acid-arginine-glycine-histidine (GMGlyil) medium, used in this experiment, was prepared by adding 25 mg. of Lhistldine HCI to $100 \mathrm{ml}$. of the GAGIy medium. The media were adjusted to the different inftial pll values with a solution of $\mathrm{NaOH}$ and duplicate flesks of each nedium were sterilized in the urual nanner. After sterlitzation the media were inoculated with a 24 hour washed cell suspension and incubated for 4 days on the shaker at $28^{\circ} \mathrm{C}$. After Incubation, growth and colorimetric mbollavin determinations were made in the usual manner. These resulte and the inftial pH values are presented in Table 31.

The growth of $\mathbf{A}$. gossxpifi was moderately affected by different inftial pll values in the $\mathrm{CA}$ medium; however, the changes were not large. In the $\mathrm{GA}$ medium, the data show a silght increased growth from pH 6.0 to a maximum growth at pH 6.4 which was followed by decreased growth to pH 6.8. The initial pll of the nedium exhibited a more pronounced effect on growth in the GaGlyil medium. At the initiel ph of 6.0 in the Gaciyll medium, the inhibitory effect of histidine vas completely elininated and growth of A. Eossypis was considerably higher than even the mextunes growth in the $G A$ mediun. Mis might Indicate that at this initial plil the histidine was in a form which decreased its active concentration and 
THE EFFECT OF INITIAL PH OF KEDIA ON GROWTH AND RIBOFLAVIN FORNATION IN THE GLUTANIC ACID - AROININE (GA) AND GLUTAMIC

ACID - AROININE - GLYCINE - HISTIDINE (GAGIYH) NEDIA

\begin{tabular}{|c|c|c|c|c|c|c|c|c|}
\hline \multirow[t]{2}{*}{ Medium } & \multirow[t]{2}{*}{$\underset{\mathrm{pH}}{\text { Indial }}$} & \multicolumn{3}{|c|}{$\begin{array}{l}\text { Dry Weight Cells } \\
(\mathrm{mg} / 20 \mathrm{ml})\end{array}$} & \multicolumn{4}{|c|}{$\begin{array}{l}\text { Ruborlavin } \\
\text { (ug/mi) (ug/mg cells) }\end{array}$} \\
\hline & & 1 & 2 & Ave. & 1 & 2 & Ave. & ive. \\
\hline$a A$ & 6.0 & 53.6 & 46.4 & 50.0 & 1.0 & 0.5 & 0.8 & 0.3 \\
\hline GA & 6.2 & 52.0 & 42.4 & 47.2 & 1.3 & 0.5 & 0.9 & 0.4 \\
\hline $\mathrm{GA}$ & 6.4 & 53.6 & 65.2 & 59.4 & 1.3 & 0.8 & 3.0 & 0.4 \\
\hline$Q A$ & 6.6 & 50.2 & 47.2 & 48.8 & 2.0 & 1.3 & 1.7 & 0.7 \\
\hline$G A$ & 6.8 & 40.0 & 42.4 & 41.2 & 3.5 & 3.5 & 3.5 & 2.7 \\
\hline GAGLyH & 6.0 & 78.0 & 80.0 & 79.0 & 6.3 & 7.5 & 6.9 & 1.7 \\
\hline GAGIyH & 6.2 & 21.2 & 10.6 & 15.9 & 7.8 & 8.5 & 8.2 & 11.7 \\
\hline CAClyH & 6.4 & 5.6 & 4.0 & 4.8 & 6.3 & 8.0 & 7.2 & 31.3 \\
\hline GAGIYII & 6.6 & 10.2 & 10.4 & 10.3 & 16.7 & 15.0 & 15.9 & 30.9 \\
\hline GAGlyHI & 6.8 & 8.4 & 4.8 & 6.6 & 11.8 & 12.0 & 11.9 & 39.1 \\
\hline
\end{tabular}

therefore it acted to stimulate growth as was ahown in Foxperiment number 19. It could also Indicate that glycine was more readily used in the growth metabolism of the organiam at this phi. When the initial pli was ratsed to 6.2 , the inhibition effect once again was apparent and the growth was decreased to approxtmately one-fifth of that obtained at the initial pil 6.0. The inhibition increased further at pll 6.4 but was slightly less at the initial pil values of 6.6 and 6.8 . The data would indicate a pil dependency for the meximum inhibitory effect by histidine on the growth of A. gossypif. 
The effect of the initial pH of the medis on riboflavin formation was evident in both serles of media. In the $\mathrm{GA}$ medium, the normal values for ribollavin formation, in the range of 0.8 ug. to 2.0 ug. per ml., were noted at initial pil values of 6.0 to 6.6 , which included the normal Initisl pll range around pil 6.5 used in most of the previous experiments. At the Initial pll of 6.8 , the ribollavin formed in the $\mathrm{C}$ medium rose to $3.5 \mathrm{ug}$. per ml. which was a rather high value for this mediun without additional anino acids. It is possible that pll 6.8 was approaching the optimumi pll for the synthegis of riboflavin and even on the $\mathrm{OA}$ medium the metabolism may shift somewhat to the synthesis of the vitamin. It shovld be pointed out, that the growth in the GA medium was least at the initial $\mathrm{pH}$ where the highest value of mbollavin was produced in the GA medium. Once again, notice is made of the formation of riboflavin at the expense of the growth of the organiam. The riboflavin which was formed In the CAGIJH medium with the infitial pll values of 6.0 through 6.4 , was slightiy below the normal values usually found in this medium; however, at the Initial pll of 6.6 , the riboflavin formed was approximately twice the value of Jields in the CAGlyll mealum at lower inftial pH values. The infilal pH of 6.6 seems to be the optimum for ribonlavin synthesis In the GAClyll medium which is in contrast to the pH 6.8 optimum for the GA medium.

\section{The Effect of Imidazole on Growth and Riboflavin Synthesis.}

Imidazole is a chemical compound which is structurally related to histidine in that 1 makes up the ring poition of the amino acid molecule. Because of this relationship, imidazole wes used to determine whether this portion of the hietidine molecule contributed to any of the inhibition 
effect produced by histidine. The $\mathrm{CA}$ and $\mathrm{CACL}$ media were propared as previously described and served as controls for the experiment. The effect of inidarole vas tested in media, prepared by adding $20.0 \mathrm{mg}$. and $30.0 \mathrm{mg}$. of imidarole, regipectively, to separate $100 \mathrm{ml}$. volumes of the GAGIy medium. For a comparison with hiatidine, two other media were prepared in the same manner as the inidazole media, except In histioine HCI was used in the place of imidasole. All media were adjusted to pH 6.5 with NaOH and duplifeate Masks of each medium were sterilized in the usual manner. The sterile media were inoculated with a 28 hour washed cell suspension and incubated for 4 days on the shaker at $28^{\circ} \mathrm{C}$. The dry weight of cells and the colorimetric riboflavin values were determined. These values are shown in Table 32.

The controls were run in addition to the inidasole medis in order to give a better comparison of some of the factors involved. The effect of imidazole was different than expected, for the addition of either concentration used, to the CAGly mediun produced an increased growth which was approxisately 20 per cent greater than the growth on the GA or the GAOIy control media. It is evident that imidarole does not demonstrate any of the Inhibition effect shown by histidine on 1. gossypil.

A milcroscoplc examination of the cells in the imiderole media showed that a large percentage of the cells were the "bulb forms" reported by Pridham and Raper (72) who showed the presence of riboflavin crystals within these cells. The number of this type cell in the inidazole media vould approximate the number of the same type cells found in $a .5$ per cent peptone medium. In the other synthetic media, where good growth occurred, there was only a small percentage of these swollen cells 
A COMPARISON OF THB EFFECT OF IMIDAZOLE WITH THAT OF HISTTDINE OA OROWTH AND RIBOFLAVIN SYITHESIS IN THE GLUTAMIC ACID - ARGININE - GLTCINE (GAOIY) MEDIUL

\begin{tabular}{|c|c|c|c|c|c|c|c|}
\hline \multirow[t]{2}{*}{ Medium } & \multirow{2}{*}{$\begin{array}{l}\text { Campound } \\
\text { Added } \\
(\mathrm{mg} / 100 \mathrm{ml})\end{array}$} & \multicolumn{3}{|c|}{$\begin{array}{l}\text { Dry Weight Cells } \\
(\mathrm{me} / 20 \mathrm{ml})\end{array}$} & \multicolumn{3}{|c|}{$\begin{array}{l}\text { Riboflavin } \\
(\mathrm{ug} / \mathrm{ml})\end{array}$} \\
\hline & & 1 & 2 & Ave. & 1 & 2 & Ave. \\
\hline $\mathrm{GA}^{*}$ & 0 & 77.2 & 84.8 & 81.0 & 2.7 & 2.5 & 2.6 \\
\hline CAGLy" & 0 & 93.6 & 77.8 & 85.7 & 12.2 & 16.7 & 14.3 \\
\hline GAGIy & $\begin{array}{l}\text { I-histidine HCI } \\
\qquad(20,0)\end{array}$ & 59.2 & 79.8 & 69.5 & 13.8 & 15.5 & 14.6 \\
\hline CACly & $\begin{array}{c}\text { I-histidine } \mathrm{BCl} \\
(30.0)\end{array}$ & 8.8 & 7.6 & 8.2 & 14.8 & 11.8 & 13.2 \\
\hline GAGIy & $\begin{array}{l}\text { Inldazole } \\
(20.0)\end{array}$ & 110.0 & 96.0 & 103.0 & 13.8 & 28.0 & 15.9 \\
\hline GACIy & $\begin{array}{l}\text { Imldezole } \\
(30.0)\end{array}$ & 114.0 & 102.0 & 108.0 & 20.8 & 21.0 & 20.9 \\
\hline
\end{tabular}

* Control media.

present, with the lower ribollavin ylelding medio having the fewer number of the cells. There were a very few of these ribonovin producing cells In the histidine inhibited mecila; however, those present were 5 to 10 times larger than the norral "bulb form" cells, which may account, to some extent, for the formation of reasonably large amounts of riboflavin under the inhibition condrtions.

There was increased riboflavin formation in the imidazole media as compared to the other media but this was probably due to the Increased number of cells present. As a result of these deta, it is apparent that more than the imidarole portion of the histidine molecule is necessary 
In the inhibition effect of histidine on the growth of $\underline{h}$. gossypif.

22. The Bffect of Different Concentrations of Glutamic Acid or Aspartic Ac1d on Growth, Ribollavin Formation and Histidine Inhibition In Synthetic Yedia. Some of the earlier experiments using the peptone medium indicated that ribonavin wes formed principally after the growth of the organiam had reached the maximum growth phase. Among other things, this could indicate that riboflavin was not formed until the nitrogenous nutrients had been nearly metabolized, thereby producing a nitrogen deficient condition in the medium. Most of the synthetic media uscd in these studies contained an appreciable amount of the main nitrogen source, namely glutaric ac1d or aspartic acid, which night prevent. a physiologically suitable condition for riboflavin synthesis after maximum growth. This experiment was perfomed to determine if lower concentrations of the main nitrogen source would have any effects on the metabolism of $\hat{A}$. gosspit in non-riboflavin producing medie and in ribollavin producing inhibition media.

The media were prepared from the basal, containing $0.01 \mathrm{~g}$. of L-arginine HCI per $100 \mathrm{ml.,}$ and by the addition of L-glutanic acid or L-espartic acid in different concentrations to form the GA or AA media. Three GA media were prepared by the addition of $0.21 \mathrm{~g} ., 0.10 \mathrm{~g}$. or $0.05 \mathrm{~g}$. of I-glutamic acid, respectively, to three different $100 \mathrm{ml}$. volumes of the basal plus arginine. Two $M$ media were prepared in a olmilar manner using $0.19 \mathrm{~g}$. or $0.10 \mathrm{~g}$. of L-aspartic acid. The glutanic acid-arginine-glycine-histidine ( $\mathrm{AACl}$ jil) and the aspartic acid-arginineglycine-histidine (AGIyi) media were prepared from each individual GA or $\mathrm{AA}$ medium by the addition of $20 \mathrm{mg}$. of glycine and $40 \mathrm{mg}$. of 
L-histidine $\mathrm{BCl}$ to $100 \mathrm{ml}$. of each Individual medium. The pll of each medium was adjusted to 6.5 with $\mathrm{NaOH}$ and duplicated Masks oterillized in the usual manner. The sterile media vere inoculated with a 28 hour washed cell suspension and Incubated for 4 days on the shaker at $28^{\circ} \mathrm{C}$. Neter incubation, the dry weight of cells and colorimetric riborlavin values were determined. These values and the concentrations of glutemic and aspartic acids are given in Table 33.

TABLE 33

THE ETFECT OF DIFTERENT CONCENTRATIONS OF L-CLUTARIC ACID AND LASPARTIC ACID ON GROWTH AND RIBOFLAVIN SWTHESIS II SWITHETIC MEDTA

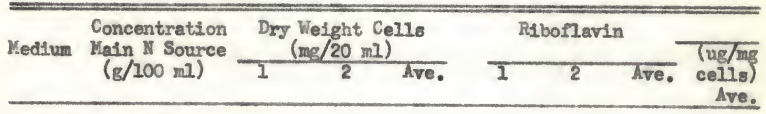

GA Cluteanic Acid

GA

$\begin{array}{llllllll}0.21 & 75.0 & 78.0 & 76.5 & 2.0 & 1.8 & 1.9 & 0.4 \\ 0.10 & 35.6 & 40.0 & 38.8 & 1.5 & 0.5 & 1.0 & 0.1 \\ 0.05 & 25.4 & 24.0 & 24.7 & 0.3 & 0.3 & 0.3 & 0.3\end{array}$

$\begin{array}{lllllllll}\text { GACLyH } & 0.21 & 2.2 & 3.4 & 2.8 & 7.5 & 8.5 & 8.0 & 2.6 \\ \text { GACLyH } & 0.10 & 1.4 & 2.6 & 2.0 & 4.5 & 5.3 & 4.9 & 3.4 \\ \text { CACLyH } & 0.05 & 1.4 & 1.2 & 1.3 & 9.5 & 7.5 & 8.5 & 7.6\end{array}$

A. Aspartic Acid

$\begin{array}{lllllllll}M & 0.19 & 73.4 & 83.4 & 78.4 & 2.3 & 1.8 & 2.1 & 0.4\end{array}$

$\begin{array}{lllllllll}\text { A } & 0.10 & 40.4 & 37.8 & 39.1 & 1.5 & 1.8 & 1.7 & 0.2\end{array}$

$\begin{array}{lllllllll}\text { MAlyli } & 0.19 & 2.2 & 2.8 & 2.5 & 9.0 & 8.5 & 8.8 & 7.2\end{array}$

\begin{tabular}{lllllllll} 
AAG1yH & 0.10 & 1.0 & 1.2 & 1.2 & 4.0 & 4.5 & 4.3 & 5.3 \\
\hline
\end{tabular}


The reduction of the amount of the main nitrogen source in the media produced a decreased growth approximately equal in degree to the reduction of the nitrogen source. In the $\mathrm{GA}$ and $M$ media, a reduction of the concentrations of glutanic and aspartic acids by one-half produced approximately one-half of the growth obtalned at the higher concentrations of $0.21 \mathrm{~g}$, and $0.19 \mathrm{~g} .$, respectively, for the amino acids. A further decrease in glutanic acid concentration to $0.05 \mathrm{~g}$. per $100 \mathrm{ml}$. of media did not produce as great a reduction in growth; however, a moderate reduction was evident.

A reduction in the riboflavin synthesized occured in the $G A$ and GAGIyll media, as weIl as the $M$ and AAGIyll media, when the concentrations of the main nitrogen sources were reduced to $0.10 \mathrm{~g}$. per $100 \mathrm{ml}$. of medis. At a glutanic acid concentration of $0.05 \mathrm{~g}$. per $100 \mathrm{ml}$. of redium in the CAClyil medium, the amount of riboflavin produced was approximately the same as that produced at the highest concentration of glutamic acid in the experiment. It is possible that at this low level of glutamic acid, the products of the glutamate metabolism may not have been at a high enough concentration to interfere with the formation of ribollavin, assuming the Inhibitory effect of dicarboxylic scid derivatives on riboflavin formation is a causative factor as was previously reported. The stimulatory effect of aspartic acid on riborlavin synthesis in the presence of glycine, which was noted in a previous experiment, did not mantfest itself under the inhibited condition of growth in the Maciyil medium. This may indicate that the aspartic acid was not metabolized as readily under these conditions to the necessary intermediates for riboflavin synthesis. However, on the basis of the amount of riboflavin per 
mg. dry weight of cells, the AA medie did show a slightly greater effect on riboflavin formation than the corresponding a media of the same relative composition.

23. Studies on Growth and Ribollavin Formation with the Addition of Glyeine to Synthetic Media at Different Times During Incubation. In studies on metabolic pathrays of biosynthesis for biologlcal compounds, It often becomes necessary to resort to tracer techniques to follow the progress of a certain compound which may be thought to be related to the pathway. The development of the synthetic GA mediwa has increased the possibility of using such techniques to study riboflavin formation under defined conditions, egpectally since a compound, such as glycine, stimulates the formation of riboflavin when added to the mediun. If a tagged compound were to be used, it would be helpful if it could be added to the medium after the growth of the organism had progressed for a period of time, and thus decrease the scattering of the tagged atom into other pathways which would be probably functioning more extensively during the early pheses of growth than would the ribonlavin synthesiging metabolisan. With this idea in mind, 1t was decided to study the effect of adding glycine to several synthetic media at different times during incubstion.

The base medium for the fIrst test was prepared from the basal by the addition of $0.21 \mathrm{~g}$. of I-glutanic acid and $0.01 \mathrm{~g}$. of Lmarginine $\mathrm{HCl}$ per $100 \mathrm{ml}$. to give the $\mathrm{GA}$ medium. The other media were prepared as follows: the GAGly medium, by adding $20 \mathrm{mg}$. of glycine per $100 \mathrm{ml}$. of GA medium; the GAGlyll medium, by adding $40 \mathrm{mg}$. of L-histIdine HCI per 100 ml. of the GAGly medium, and the glutramic acid-arginine-histidine (GAH) medium, by adding $40 \mathrm{mg}$. of L-histidine $\mathrm{BCl}$ per $100 \mathrm{ml}$. of the GA medium. 
411 medis were then sterilized, inoculated with a 28 hour washed cell suspension and incubated for 4 days on the shaker at $28^{\circ} \mathrm{C}$. For the delayed action Masks of media, a sterile glyeine solution, containing $4 \mathrm{mg}$. of glycine per ml. of distilled water, was added to the cultures in the GA and CAH media to give a concentration of $20 \mathrm{mg}$. of glycine per $100 \mathrm{ml}$. of media, the same concentration $8 \mathrm{~s}$ that in the GAGIy and GAGIyI medis. After incubation, the dry welght of cells and the colorimetric riboflavin values were determined in the usual maner. These velues and the times of the additions of glycine are given in Table 34.

\section{TABLE 34}

THE EFFECT OF GLYCINE ON GRONTH AND RTBOFLAVIN FORMATION DURING FOUR DAYS INCUBATION IN SYNTIETIC MEDIA WITH GLYCINE ADDED AT DIFFERENT TDES DURING INCUBATION

\begin{tabular}{|c|c|c|c|c|c|c|c|}
\hline \multirow[t]{2}{*}{ Mediun } & \multirow{2}{*}{$\begin{array}{l}\text { Tine Glycine } \\
\text { Added } \\
\text { (hours) }\end{array}$} & \multicolumn{3}{|c|}{$\begin{array}{l}\text { Dry Welght Cells } \\
(\mathrm{mg} / 20 \mathrm{ml})\end{array}$} & \multicolumn{3}{|c|}{$\begin{array}{l}\text { Ribollavin } \\
(\mathrm{ag} / \mathrm{ml})\end{array}$} \\
\hline & & 1 & 2 & Ave. & 1 & 2 & Ave. \\
\hline $\mathrm{GA}$ & 0 & 57.4 & 66.8 & 62.1 & 2.5 & 2.0 & 2.3 \\
\hline GAGIy & 0 & 57.8 & 64.2 & 61.0 & 15.5 & 16.5 & 16.0 \\
\hline GA & 24 & 51.4 & 60.0 & 55.7 & 5.3 & 6.0 & 5.7 \\
\hline $\mathrm{GA}$ & 48 & 66.8 & 87.6 & 77.2 & 8.8 & 5.5 & 7.2 \\
\hline GAH & 0 & 6.8 & 4.4 & 5.1 & 5.5 & 5.5 & 5.5 \\
\hline GAGIyH & 0 & 14.1 & 12.8 & 13.5 & 16.3 & 14.3 & 15.3 \\
\hline GAH & 24 & 8.4 & 12.1 & 10.3 & 5.8 & 8.3 & 7.1 \\
\hline $\mathrm{CAH}$ & 48 & 7.2 & 6.2 & 6.7 & 6.0 & 6.8 & 6.4 \\
\hline
\end{tabular}

The data show that riboflavin was synthesized in the GA nasks 
to which glycine was adied after 24 hours, or 48 hours' incubation, to approximately the same extent for either time of addition of the compound. The yield of riboflavin resulting from the late addition of glyeine was considerably lower than that obtained for the GAGly medium in which the glyeine was present from the beginning of the incubation. This could be explained if the glycine was necessary in the early stages of growth in order to make some intermediate in riboflavin synthesis which could not be formed in an effective concentration in the GA medium alone. However, on this basis the medium with glycine added at 24 hours would be expected to yleld more riboflavin than the medium where the glycine was added at 48 hours, but thils was not the case according to the results. The 48 -hour addition of glycine to GA medium produced an increased growth which may indicate a more direct incorporation of glycine into growth when added to this mediun after appreciable growth was already present.

This test of additions of Blycine to the $G A$ and $G A B$ media after growth had been underway for a time was repeated, using more controls in order to obatin a clearer picture of the effect of added glycine at different times during incubation. In addition, longer incubation times after the addition of glycine were used. The sterile GA, GACly, GACIyH and GAH medila and the sterile solution of glycine used for additions of glycine to the $\mathrm{GA}$ and $\mathrm{GAH}$ media during growth were prepared as described above. The sterlie media were inoculated with a 28-hour-washedcell suspension and incubated on the shaker at $28^{\circ} \mathrm{C}$. After the addition of glycine to the incubated GA and GAH medis at 24 and 488 hours, the growth was allowed to contimue until a full 96 hour incubation period had been attained after each addition, which meant that there were 120 hours 
and 14,4 hours total incubation periods, respectively, for the flasks with glycine added during growth. Some of the flasks of $\mathrm{CA}$ and CAH media to which glycine had been added were renoved after 96 hours total incubation in order to give short period incubations to compare with those media where glyeine was added indtially. After incubation, the dry cell weight and the colorimetric riboflavin values were determined in the usual manner. These values and the times of the additions of glycine are reported in Table 35.

The delayed addition of glycine to the GA medium showed approximately the same yield of ribollavin for either the 24 hour or the 48 hour addition of the glycine. The riboflavin produced in these media was less than that produced in the GACIy medium incubated for 96 hours even though the media with delayed addition of glycine did have the same incubation time with glycine in the media. This may indicate that glycine, which was added after the growth had pro ressed, entered into the growth metabollam of the organiam rather than into the synthesis of riboflavin since the growth in the 96 hour GA medium after delayed addition of glycine wes greater than that of the 1011 I4 hour incubation of the GAGly medium. Some of the inhibition of the synthesis of riboflavin in the GA medium with delayed addition of glycine mey have been due to the formation of some ribolavin inhibitory metabolic products during the early growth of the orgentsm.

In the histidine inhtbited GAH medium, there was a slight increase in ribollavin over the $G A$ control which may indicate a relationship of histidine to riboflavin synthesis; howerer, due to the inhibition of growth, the metabolism of glutamic acid and arginine may be forced into 
TABLE 35

THE EFFECT OR DRLAYED ADDITION OF GLYCINE ON GBOWTY AND RIBOFLAVIN FOPUATTON IN SMNTHETIC MEDIA

\begin{tabular}{|c|c|c|c|c|c|c|c|c|}
\hline \multirow[t]{2}{*}{ Nedi um } & \multirow{2}{*}{$\begin{array}{l}\text { Hour } \\
\text { Giycine } \\
\text { Added }\end{array}$} & \multirow{2}{*}{$\begin{array}{c}\text { Incubation } \\
\text { TIme } \\
\text { (hours) }\end{array}$} & \multicolumn{3}{|c|}{$\begin{array}{c}\text { Dry Weight Cells } \\
(\mathrm{mg} . / 20 \mathrm{ml}) \\
\end{array}$} & \multicolumn{3}{|c|}{$\begin{array}{l}\text { Rtboflavin } \\
\text { (ug/mi) }\end{array}$} \\
\hline & & & 1 & 2 & Ave. & $I$ & 2 & Ave. \\
\hline $\mathrm{GA}$ & - & 96 & 54.3 & 36.0 & W.7 & 2.5 & 3.2 & 2.9 \\
\hline $\mathrm{CA}$ & - & 124 & 31.4 & 33.8 & 32.6 & 2.5 & 3.2 & 2.9 \\
\hline GACly & 0 & 48 & 29.6 & 27.4 & 28.5 & 2.8 & 3.0 & 2.9 \\
\hline GAOIy & 0 & 72 & 34.2 & 34.2 & 34.2 & 8.3 & 9.0 & 8.7 \\
\hline GAGZy & 0 & 96 & 34.0 & 39.8 & 36.9 & 7.5 & 20.3 & 8.7 \\
\hline GACly & 0 & 144 & 37.6 & 42.6 & 40.1 & 8.0 & 12.5 & 10.3 \\
\hline GA & 24 & 72 & 35.4 & 33.2 & 34.3 & 5.8 & 5.5 & 5.6 \\
\hline $\mathrm{GA}$ & 24 & 120 & 49.0 & 24.2 & 36.6 & 6.0 & 4.0 & 5.0 \\
\hline $\mathrm{GA}$ & 48 & 48 & 35.4 & 37.2 & 36.3 & 4.8 & 5.3 & 5.1 \\
\hline $\mathrm{GA}$ & 48 & 1144 & 43.6 & 54.8 & 49.2 & 5.3 & 5.8 & 5.6 \\
\hline $\mathrm{GAH}$ & - & 96 & 3.4 & 3.6 & 3.5 & 5.3 & 3.5 & 4.4 \\
\hline GAH & - & $\mathrm{N}_{14}$ & 2.8 & 4.8 & 3.8 & 5.3 & 5.8 & 5.6 \\
\hline GAOLyH & 0 & 48 & 7.2 & 6.4 & 6.8 & 3.4 & 3.5 & 3.4 \\
\hline GAOlyil & 0 & 72 & 5.0 & 4.0 & 4.5 & 12.5 & 21.4 & 11.4 \\
\hline GAGlyd & 0 & 96 & 4.4 & 4.2 & 4.3 & 7.5 & 9.3 & 8.4 \\
\hline OralyH & 0 & 14,4 & 3.8 & 3.8 & 3.8 & 20.0 & 11.3 & 10.7 \\
\hline GAH & 24 & 72 & 4.8 & 4.2 & 4.5 & 9.3 & 9.5 & 9.4 \\
\hline GAH & 24 & 120 & 5.6 & 2.6 & 4.1 & 8.3 & 8.5 & 8.4 \\
\hline GAH & 48 & 48 & 3.2 & 6.0 & 4.6 & 6.5 & 8.0 & 7.3 \\
\hline GAH & 48 & 144 & 8.2 & 7.4 & 7.8 & 7.8 & 11.0 & 9.4 \\
\hline
\end{tabular}


the direction of riboflavin formation. In the GAH media where glycine was added at 24 and 48 hours, the riboflavin formed was approximately equal to that produced in the GAClyH medium where glycine was present at the time of inoculation. This would indicate that the late addition of glycine to the hratidine inhibited media had little effect on the extent of riborlavin synthesis.

The amall yields of riboflavin obtained after the delayed addition of glycine to the $O A$ medium would make difficult the use of tagged compounds in studies on the biosynthesis of riboflavin under these conditions unless ylelds could be increased; however, their use In the histidine inhibited media might have possibilities.

24. Studies on Growth and Riboflavin Synthesis in the Glutamic Acid-Arginine-listidine Nedium with Different Concentretions of Amino Acids. The discovery of the Inhibition effect of histidine offered an opportunity to study the effects of amino acids on ribonavin gynthesis by eliminating, to a large extent, the growth metabolisan of $\mathbb{A}$. gossypil while ribollavin synthesis continued. Under these conditions, the addition of precursors or other compounds may be studied with the hope that a clearer pattern of the compounds which are related to the synthesis of riboflavin would appear. The following serles of tests was such an attempt, in which a number of anino acids were studied for their effect on riboflavin formation in a histidine inhibited cell system. CA medium was prepared from the basal and contained $0.05 \mathrm{~g}$. of Inglutamic acld and $0.01 \mathrm{~g}$. of Larginine $\mathrm{HCl}$ per $100 \mathrm{ml}$. of the basal. The lower concentration of glutamic acld as compared v1th $0.21 \mathrm{~g}$. per $200 \mathrm{ml}$. In previous media was used to eliminate possible inhibitory effects on 
riborlavin synthesis that might result from the higher concentration usually used. The lower concentration of glutanic acid was shown in a previous experiment to be satisfactory for the formation of riboflavin in the histidine inhibition medium. The GAH medium was prepared from the GA medium by adding $40 \mathrm{mg}$. of Lmistidine $\mathrm{HCl}$ to $100 \mathrm{ml}$. of the $\mathrm{CA}$ mediuse just described. The GA and GAH media and the GAH medium plus 20 mg. of glycine per $100 \mathrm{ml}$. were used as controls throughout the experiment. Other speciel media except that with methionine were prepered from the GAll medium by the addition of $5.0,10.0,20.0$ and $40.0 \mathrm{mg}$. quantities of the Individual amino acidg to be studied and were sterilized. The methionine, which was used in one part of the experiment, was prepared as a solution and sterilized by Seitz filtration before the eddition to the sterile media. A 28 hour washed cell suspension of A. gossypil was used for each inoculation throughout the experiment. Because of space Iimitations on the shaker, the experiment was carried out with three amino acids and controls for each test. The inoculated media were shaken for 4 days at $28^{\circ} \mathrm{C}$., after which they were removed from the shaker and the dry weight of cells and colorimetric determination of ribonavin made in the usuel manner. The results along with the anino acids used, with their concentrations, are presented in Table 36.

In all of the experiments, the riborlavin produced in the GA mediun controls was of a low level as had been expected. The growth in the $\mathrm{GA}$ medium controls was within reasonable agreement among the different experiments, ranging from $22.9 \mathrm{mg}$. to $36.6 \mathrm{mg}$. dry weight of cells per $20 \mathrm{ml}$. of medium. The GAH control gave the expected inhibition of growth in all of the experiments with the dry weight of cells ranging from less 
TABLE 36

THE GROWTH AND RIBOFLAVIN FORMATION IN THE GLUTAMIC ACID - ARGININE HISTININE (GAH) MEDIUM WITH DIFFERENT CONCENTRATIONS

\section{OF DIFFERERT AMINO ACIDS}

\begin{tabular}{|c|c|c|c|c|c|c|c|c|}
\hline \multirow[t]{2}{*}{ Medium } & \multirow{2}{*}{$\begin{array}{l}\text { Amino Acld } \\
\text { Added } \\
\text { (mg/100 ml) }\end{array}$} & & \multicolumn{3}{|c|}{$\begin{array}{l}\text { Dry Welght Cells } \\
(\mathrm{mg} / 20 \mathrm{ml})\end{array}$} & \multicolumn{3}{|c|}{$\begin{array}{c}\text { Riborlavin } \\
\text { (ug/ml) }\end{array}$} \\
\hline & & & 1 & 2 & Ave. & 1 & 2 & Ave. \\
\hline $\mathrm{CA}^{*}$ & $-\infty$ & & 31.8 & 30.1 & 30.9 & 1.5 & 3.5 & 1.5 \\
\hline GAH" & $-\infty$ & & 1.0 & $<1.0$ & $<1.0$ & 5.3 & 4.7 & 5.0 \\
\hline GAH & Clyeine & $\begin{array}{r}5.0 \\
10.0 \\
20.0 \\
40.0\end{array}$ & $\begin{array}{r}<1.0 \\
1.4 \\
3.0 \\
<1.0\end{array}$ & $\begin{array}{r}1.2 \\
1.8 \\
1.4 \\
<1.0\end{array}$ & $\begin{array}{r}<1.1 \\
1.6 \\
2.2 \\
<1.0\end{array}$ & $\begin{array}{r}6.8 \\
6.8 \\
7.8 \\
10.8\end{array}$ & $\begin{array}{r}6.0 \\
7.0 \\
9.2 \\
10.3\end{array}$ & $\begin{array}{r}6.4 \\
6.9 \\
8.5 \\
10.5\end{array}$ \\
\hline GAH & L-proline & $\begin{array}{r}5.0 \\
10.0 \\
20.0 \\
160.0\end{array}$ & $\begin{array}{r}1.4 \\
<1.0 \\
<1.0 \\
1.0\end{array}$ & $\begin{array}{l}1.8 \\
3.2 \\
1.0 \\
4.0\end{array}$ & $\begin{array}{r}1.6 \\
<1.1 \\
<1.0 \\
2.5\end{array}$ & $\begin{array}{l}6.5 \\
4.5 \\
4.5 \\
4.4\end{array}$ & $\begin{array}{l}6.0 \\
5.0 \\
5.0 \\
5.2\end{array}$ & $\begin{array}{l}6.2 \\
4.8 \\
4.8 \\
4.8\end{array}$ \\
\hline GAH & L-leucine & $\begin{array}{r}5.0 \\
10.0 \\
20.0 \\
40.0\end{array}$ & $\begin{array}{l}1.6 \\
1.8 \\
5.8 \\
5.4\end{array}$ & $\begin{array}{l}1.4 \\
1.0 \\
2.6 \\
5.8\end{array}$ & $\begin{array}{l}1.5 \\
1.4 \\
4.2 \\
5.6\end{array}$ & $\begin{array}{r}4.0 \\
6.2 \\
11.8 \\
12.5\end{array}$ & $\begin{array}{r}4.5 \\
5.8 \\
7.8 \\
14.5\end{array}$ & $\begin{array}{r}4.3 \\
6.0 \\
9.8 \\
13.5\end{array}$ \\
\hline$-\cdots$ & $\ldots-$ & & - & - & $\cdots$ & $\cdots$ & $-\cdots$ & -- \\
\hline$G A^{*}$ & $-\infty$ & & 22.4 & 23.4 & 22.9 & 0.5 & 0.8 & 0.7 \\
\hline $\mathrm{CAHI}^{*}$ & $-\infty$ & & $<1.0$ & $<1.0$ & $<1.0$ & 3.3 & 4.8 & 4.1 \\
\hline GAH & Olycine & 20.0 & 1.2 & 1.0 & 1.1 & 8.5 & 8.3 & 8.4 \\
\hline GAH & L-tyrosine & $\begin{array}{r}5.0 \\
10.0 \\
20.0 \\
40.0\end{array}$ & $\begin{array}{r}<1.0 \\
<1.0 \\
1.0 \\
<1.0\end{array}$ & $\begin{array}{r}1.0 \\
<1.0 \\
<1.0 \\
1.0\end{array}$ & $\begin{array}{l}<1.0 \\
<1.0 \\
<1.0 \\
<1.0\end{array}$ & $\begin{array}{l}5.3 \\
6.5 \\
5.8 \\
6.0\end{array}$ & $\begin{array}{l}6.5 \\
6.0 \\
5.8 \\
7.3\end{array}$ & $\begin{array}{l}5.9 \\
6.3 \\
5.8 \\
6.7\end{array}$ \\
\hline GAH & $\begin{array}{l}\text { DL-trypto- } \\
\text { phane }\end{array}$ & $\begin{array}{r}5.0 \\
10.0 \\
20.0 \\
40.0\end{array}$ & $\begin{array}{r}<1.0 \\
1.2 \\
4.0 \\
3.8\end{array}$ & $\begin{array}{r}<1.0 \\
1.0 \\
7.6 \\
3.0\end{array}$ & $\begin{array}{r}<1.0 \\
1.1 \\
5.8 \\
3.4\end{array}$ & $\begin{array}{l}5.3 \\
6.0 \\
8.5 \\
8.5\end{array}$ & $\begin{array}{r}7.3 \\
5.8 \\
10.0 \\
8.0\end{array}$ & $\begin{array}{l}6.3 \\
5.9 \\
9.3 \\
8.3\end{array}$ \\
\hline GAH & In-lysine & $\begin{array}{r}5.0 \\
10.0 \\
20.0 \\
40.0\end{array}$ & $\begin{array}{l}4.8 \\
1.2 \\
1.0 \\
1.2\end{array}$ & $\begin{array}{l}2.8 \\
2.6 \\
1.0 \\
1.4\end{array}$ & $\begin{array}{l}3.8 \\
1.9 \\
1.0 \\
1.3\end{array}$ & $\begin{array}{l}7.0 \\
7.0 \\
7.0 \\
7.3\end{array}$ & $\begin{array}{l}5.8 \\
7.8 \\
7.0 \\
8.8\end{array}$ & $\begin{array}{r}6.4 \\
3.4 \\
8.0 \\
8.1\end{array}$ \\
\hline
\end{tabular}


TABLE 36 (continued)

\begin{tabular}{|c|c|c|c|c|c|c|c|c|}
\hline \multirow[t]{2}{*}{ Medium } & \multirow{2}{*}{\multicolumn{2}{|c|}{$\begin{array}{l}\text { Amino Acid } \\
\text { Added } \\
(\mathrm{mg} / 100 \mathrm{ml})\end{array}$}} & \multicolumn{3}{|c|}{$\begin{array}{l}\text { Dry Weight Cells } \\
(\mathrm{mg} / 20 \mathrm{ml})\end{array}$} & \multicolumn{3}{|c|}{$\begin{array}{c}\text { Riboravin } \\
(\mathrm{ug} / \mathrm{ml})\end{array}$} \\
\hline & & & 1 & 2 & ave. & 1 & 2 & Ave. \\
\hline $\mathrm{GA}^{*}$ & $\cdots$ & & 32.2 & 26.4 & 29.4 & 0.5 & 0.8 & 0.6 \\
\hline $\mathrm{GAH}^{*}$ & - & & 3.8 & 1.8 & 2.8 & 3.8 & 5.0 & 4.4 \\
\hline $\mathrm{CAH}^{*}$ & Giycine & 20.0 & 1.2 & 3.4 & 2.3 & 8.3 & 9.0 & 8.7 \\
\hline GAH & I-eystine & $\begin{array}{r}5.0 \\
10.0 \\
20.0 \\
40.0\end{array}$ & $\begin{array}{r}7.8 \\
19.8 \\
21.4 \\
22.4\end{array}$ & $\begin{array}{l}19.0 \\
23.4 \\
21.6 \\
21.2\end{array}$ & $\begin{array}{l}13.4 \\
21.6 \\
21.5 \\
21.8\end{array}$ & $\begin{array}{l}9.3 \\
4.8 \\
3.0 \\
3.0\end{array}$ & $\begin{array}{l}8.5 \\
8.3 \\
4.0 \\
3.0\end{array}$ & $\begin{array}{l}8.9 \\
6.6 \\
3.5 \\
3.0\end{array}$ \\
\hline GAH & Ineerine & $\begin{array}{r}5.0 \\
10.0 \\
20.0 \\
40.0\end{array}$ & $\begin{array}{l}2.8 \\
1.8 \\
3.6 \\
4.4\end{array}$ & $\begin{array}{l}5.2 \\
2.2 \\
3.4 \\
5.4\end{array}$ & $\begin{array}{l}4.0 \\
2.0 \\
3.5 \\
4.9\end{array}$ & $\begin{array}{r}8.8 \\
11.0 \\
9.3 \\
8.5\end{array}$ & $\begin{array}{l}11.0 \\
11.0 \\
13.0 \\
11.8\end{array}$ & $\begin{array}{r}9.9 \\
11.0 \\
11.2 \\
10.2\end{array}$ \\
\hline GAH & I-threonine & $\begin{array}{r}5.0 \\
10.0 \\
20.0 \\
40.0\end{array}$ & $\begin{array}{l}3.0 \\
3.0 \\
5.8 \\
5.2\end{array}$ & $\begin{array}{l}5.2 \\
4.2 \\
4.8 \\
4.4\end{array}$ & $\begin{array}{l}4.1 \\
3.6 \\
5.3 \\
4.8\end{array}$ & $\begin{array}{r}7.0 \\
6.8 \\
10.0 \\
11.0\end{array}$ & $\begin{array}{l}7.3 \\
6.8 \\
9.5 \\
9.3\end{array}$ & $\begin{array}{r}7.2 \\
6.8 \\
9.8 \\
10.2\end{array}$ \\
\hline $\mathrm{CA}^{*}$ & $\ldots$ & & 37.8 & 35.4 & 36.6 & 1.0 & $0 . \overline{8}$ & 0.9 \\
\hline GAH $^{*}$ & $-\infty$ & & 2.6 & 3.0 & 2.8 & 3.8 & 4.3 & 4.1 \\
\hline $\mathrm{GAI}^{*}$ & Gyjeine & 20.0 & 2.8 & 4.2 & 3.5 & 5.8 & 6.5 & 6.2 \\
\hline CAH & I-alanine & $\begin{array}{r}5.0 \\
10.0 \\
20.0 \\
40.0\end{array}$ & $\begin{array}{l}4.3 \\
2.8 \\
2.2 \\
1.4\end{array}$ & $\begin{array}{l}2.6 \\
2.4 \\
1.8 \\
2.0\end{array}$ & $\begin{array}{l}3.0 \\
2.6 \\
2.0 \\
1.7\end{array}$ & $\begin{array}{l}3.8 \\
3.8 \\
3.8 \\
4.5\end{array}$ & $\begin{array}{l}2.8 \\
3.8 \\
4.0 \\
4.8\end{array}$ & $\begin{array}{l}3.3 \\
3.8 \\
3.9 \\
4.6\end{array}$ \\
\hline CAH & $\begin{array}{l}\text { DL-phenyl- } \\
\text { alanine }\end{array}$ & $\begin{array}{r}5.0 \\
10.0 \\
20.0 \\
40.0\end{array}$ & $\begin{array}{l}2.0 \\
1.8 \\
1.6 \\
4.0\end{array}$ & $\begin{array}{l}4.8 \\
1.4 \\
2.4 \\
3.0\end{array}$ & $\begin{array}{l}3.4 \\
1.6 \\
2.0 \\
3.5\end{array}$ & $\begin{array}{l}4.0 \\
4.5 \\
4.5 \\
4.3\end{array}$ & $\begin{array}{l}4.5 \\
4.5 \\
4.5 \\
5.3\end{array}$ & $\begin{array}{l}4.3 \\
4.5 \\
4.5 \\
4.8\end{array}$ \\
\hline GAH & $\begin{array}{l}\text { DL-iso- } \\
\text { leucine }\end{array}$ & $\begin{array}{r}5.0 \\
10.0 \\
20.0 \\
40.0\end{array}$ & $\begin{array}{l}2.6 \\
3.0 \\
3.0 \\
3.2\end{array}$ & $\begin{array}{l}3.0 \\
1.8 \\
2.4 \\
1.8\end{array}$ & $\begin{array}{l}2.8 \\
2.4 \\
2.7 \\
2.5\end{array}$ & $\begin{array}{l}4.0 \\
4.5 \\
5.3 \\
5.3\end{array}$ & $\begin{array}{l}5.0 \\
4.3 \\
5.3 \\
5.3\end{array}$ & $\begin{array}{l}4.5 \\
4.4 \\
5.3 \\
5.3\end{array}$ \\
\hline
\end{tabular}

(Table continued on following page) 


\begin{tabular}{|c|c|c|c|c|c|c|c|c|}
\hline \multirow[t]{2}{*}{ Medium } & \multirow{2}{*}{$\begin{array}{c}\text { Added } \\
\text { Amino Ac1d } \\
\text { (mg/100 ml) }\end{array}$} & & \multicolumn{3}{|c|}{$\begin{array}{l}\text { Dry Weight Cells } \\
(\mathrm{mg} / 20 \mathrm{ml})\end{array}$} & \multicolumn{3}{|c|}{$\begin{array}{c}\text { Riboflavin } \\
(\mathrm{ug} / \mathrm{ml})\end{array}$} \\
\hline & & & 1 & 2 & Ave. & 1 & 2 & Ave. \\
\hline$G A^{*}$ & $--\infty$ & & 30.8 & 32.8 & 31.8 & 1.0 & 1.0 & 1.0 \\
\hline $\mathrm{OAH}^{*}$ & - & & 2.6 & 2.0 & 2.3 & 5.0 & 5.0 & 5.0 \\
\hline $\mathrm{CAH}^{*}$ & Glycine & 20.0 & 1.6 & 1.8 & 1.7 & 10.8 & 9.7 & 10.3 \\
\hline GAH & $\begin{array}{l}\text { L-methio- } \\
\text { nine }\end{array}$ & $\begin{array}{r}5.0 \\
10.0 \\
20.0 \\
40.0\end{array}$ & $\begin{array}{l}18.0 \\
22.2 \\
35.4 \\
50.4\end{array}$ & $\begin{array}{l}15.8 \\
15.0 \\
30.1 \\
45.2\end{array}$ & $\begin{array}{l}16.9 \\
18.6 \\
32.8 \\
47.8\end{array}$ & $\begin{array}{l}4.8 \\
4.5 \\
3.5 \\
4.5\end{array}$ & $\begin{array}{l}4.5 \\
4.8 \\
5.0 \\
4.3\end{array}$ & $\begin{array}{l}4.7 \\
4.7 \\
4.3 \\
4.4\end{array}$ \\
\hline GAH & Luraline & $\begin{array}{r}5.0 \\
10.0 \\
20.0 \\
40.0\end{array}$ & $\begin{array}{l}3.0 \\
3.0 \\
2.0 \\
3.2\end{array}$ & $\begin{array}{l}3.6 \\
3.2 \\
2.0 \\
3.6\end{array}$ & $\begin{array}{l}3.3 \\
3.1 \\
2.0 \\
3.4\end{array}$ & $\begin{array}{l}5.0 \\
6.0 \\
5.8 \\
5.8\end{array}$ & $\begin{array}{l}5.3 \\
5.3 \\
5.5 \\
6.3\end{array}$ & $\begin{array}{l}5.2 \\
5.7 \\
5.7 \\
6.1\end{array}$ \\
\hline CAH & $\begin{array}{l}\text { Beta- } \\
\text { alanine }\end{array}$ & $\begin{array}{r}5.0 \\
10.0 \\
20.0 \\
40.0\end{array}$ & $\begin{array}{l}1.8 \\
2.2 \\
4.2 \\
2.6\end{array}$ & $\begin{array}{l}2.6 \\
2.4 \\
2.2 \\
2.6\end{array}$ & $\begin{array}{l}2.2 \\
2.3 \\
3.2 \\
2.6\end{array}$ & $\begin{array}{l}6.5 \\
7.5 \\
7.5 \\
7.0\end{array}$ & $\begin{array}{l}5.8 \\
8.3 \\
8.0 \\
9.0\end{array}$ & $\begin{array}{l}6.2 \\
7.9 \\
7.8 \\
8.0\end{array}$ \\
\hline
\end{tabular}

* Control media.

than $1.0 \mathrm{mg}$. to $2.8 \mathrm{mg}$. per $20 \mathrm{ml}$. of medium. The riboflavin formed in the GAH control medium was in the range of 4.1 to 5.0 ug. per ml. which was an average of $3.5 \mathrm{ug}$. per nl. higher than the riborlavin produced in the GA control medium. This would indicate that hiatidine, at the concentration used in the CAH medium, may have some effect on riboflavin gynthesis. If the growth metabolism of A. gossyp11 is considerably disturbed under these inhibited conditions, the metabolison of glutanic acid and arginine may bo forced Into other pathways than those for growth, thus some riboflavin may be formed as a result of theis changed metabolle products. If such were the case, it would indicate an indirect function of histidine on riboflavin synthesis; however, under these same 
conditions histidine may also be assumed to be more directly involved in ribollavin formation.

A total of 15 anino acids vere studied, in this serles of tests, with reapect to their effects on formation of riboflavin in the histidine inhibited cell system. In keeping with the other experiments, grovth was also determined in conjunction with riborlavin synthesis. The growth inhibition by histidine was not signiflcently affected by the saino aclds, glycine, Lmproline, L-tyrosine, L-alanine, DL-phenylalanine, DLwisolescine, Luvaline or Beta-alanine when added to the GAH media. Assuming the concentration of these anino acids is high enough to overcome any histidine Inhibition of their metabolisms, the data would seem to indicate that histidine was not inhibitory to the growth of A. gossyoif by blocking the metabolims of any of these amino aclds.

I-leucine, DL-tryptophane, I-verine or L-threonine showed a slight effect in the histidine inhibition when the $20.0 \mathrm{mg}$. or $40.0 \mathrm{mg}$. concentrations were added to the $\mathrm{GAH}$ medium as shown by the slightly increesed growth over the CAH control medium. When only $5.0 \mathrm{mg}$. of I-lysine HCI was added to the GAH medium, there was a sIlght increase in growth over the GAH control, but at the higher concentrations of Iysine there was no longer any such effect noted.

The sulfur containing amino acids had a large effect on the histiatine inhibition of A. gossypif cell growth. The addition of $5.0 \mathrm{ng}$. or $10.0 \mathrm{mg}$. of Imcystine to $100 \mathrm{ml}$. of the $\mathrm{GAH}$ medius realted in $13.4 \mathrm{mg}$. or $21.6 \mathrm{mg}$. dry welght of cells, respectively, which was approxinately one-half or two-thirds, of the uninhibited cell growth in the GA control medium. L-methionine was even more effective in relieving the histidine 
inhibition of growth. The growth in the GAH medium when $20 \mathrm{mg}$. of I-methionine per $100 \mathrm{ml}$. was added, equalled that forned in the $\mathrm{GA}$ control mediun. At the concentration of $40 \mathrm{mg}$. of methionine per 100 ml. of the GAH medivm, the growth in the CAAl mediun exceeded that of the uninhibited GA control medium by approximately 50 per cent. This strongly suggests that the histidine inhibition may be due to a blocking of the sulfur metabolism of $A$. gossypii as related to either the formation of methionine or the function of methionine in the growth metabolism.

An examination of the effects on riboflavin synthesis showed that the amino acids L-alanino, DL-phenylaranine, DL-isoleucine, L-valine and L-methionine apparently had no stimulating effect on the synthesis of riboflavin in the GAH medium. It is of interest to note that methionine did not stimulate ribollavin synthesis even though it relfeved the histidine inhibition of growth. This would create a condition similar in some respects to growth in the GA mediun vithout histidine; however, the yield of riboflavin is considerably higher than that in the GA control which seems to indicate an effect by histidine on formation of ribollavin. Thus, it would appear that histidine might have a dual effect, one as a growth inhibitor and the other as a stimulator for riboflavin synthesis.

Luproline and L-tyrosine appeared to show a slightly increased riborlavin synthesis over the GAil control when 5.0 mg. of the amino acids was added to $100 \mathrm{ml}$. of the medium. At higher concentrations of these amino acids, tyrosine showed no further effect but in the case of proline there was a reduction to the value of the control. These anino 
acids showed no significant effect on histidine inhibition.

There was a moderate but significant increase in riboflavin formation when L-lysine HCI, Beta-alanine or DL-tryptophane was added to the GAH med1um. In the cases of 1 yolne and tryptophane, the synthesis increased as the anount of the anino acld added was increased; however, in the case of Betamalanine, the raximun anount of riboflavin was formed when $10.0 \mathrm{mg}$. of the amino ac1d was added to $100 \mathrm{ml}$. of the CAH medium and further additions produced no increase.

One of the most striking anino acld effects was shown by Irocystine which stimulated both growth and formation of riboflavin when $5.0 \mathrm{mg}$. of the amino acld was added to $100 \mathrm{ml}$. of the GAH medium. As the concentration of cystine was increased the amount of riboflavin formed was ahown to decrease, accompanied by an Increase in growth of the organism. At the higher concentrations of cystine, the conditions in the mediun, with respect to riboflavin synthesis, becane similar to those in the GAH control which indicates again the possible dual function of histidine as discussed in the case of methionine.

Large effects on riboflavin formation were denonstrated by the addition of the anino acids gljcine, L-leucine, L-serine or L-threonine to the GAH medium. Gycine, leucine or threonine showed a gradual increased synthesis of riboflavin with increasing amounts of the amino ac1ds to the GAH medium. Serine showed increased ribollavin fornation at concentrations up to and including $10.0 \mathrm{mg}$. per $100 \mathrm{ml}$; however, at higher concentrations of the amino acid no further stinulation or $\mathrm{Mbo-}$ Mavin synthesis was show. Of all the amino acids leucine showed the largest amount of riboflavin formed when it was added at a concentration 
of $40.0 \mathrm{mg}$. per $100 \mathrm{ml}$. of the GAH medium.

The interrelationships of these amino acids with regpect to riboflavin formation and/or growth offer a conslderable fleld for speculation. The effect of cygtine and methionine on the histidine inhibition has already been discussed; however, it is worth noting in Figure I, page 18 , that these two aminn acids can be related to each other in the anino acid metabolic scheme. The fact that cystine vas less effective than methionine in relieving the histidine inhibition may indicate only a partial. conversion of cystine to whatever is necessary to completely relieve the histidine inhibition. The initial addition of $5.0 \mathrm{mg}$. of cystine per $100 \mathrm{ml}$. nay give rise to increased riboflavin because of the possible formation of serine which has been shown to stimalate riboflavin formation; however, the rate of the formation of serine may be a limiting step which would allow only a certain conversion of cystine to serine. Therefore, when increased anounts of cyatine are added the large excess present forces the formation of the inhibition relieving substance which in turn Inhibits the formation of any miborlavin. This secms to be verified by the fact that increased concentrations of cystine produced an increased Inhibition of ribonlavin synthesis even though appreciable growth had occured. On the other hand, nethionine probably went directly into the system which relieved the histidine inhibition and as a reault riboflavin formation was inhibited as a result of the processes involving the growth of the organism.

The other amino acids, which had a slight relieving effect on the histidine inhibition, have no direct interrelationships with one another or with methionine (see Figure 1). Threonine may have been able to show 
its slight rellef of Inhibition through methionine due to the relationshtp of the former to homoserine which in turn may form a small mount of methionine.

$A_{\mathbf{s}}$ a result of the effects of the amino acids on the synthesis of riboflavin, scme Interesting facts were brought to Iight. Tyrosine and tryptophane, which are related in Figure 1, did show a stimulating effect on riborlevin formation, with tryptophene being more readily metabolized than the tyrosine. The limited solubility of tyrosine may have been another factor which linited 1ts effectiveness toward riboRavin formation.

The stinulation of ribollavin synthesis by $5.0 \mathrm{mg}$. of L-proline and the reversal, on the addition of $10.0 \mathrm{mg}$. of the amino acid was rather difficult to explain. However, in the case of cystine, if proline, at low concentrations, did metabolize to some precursor by a slow reaction, the presence of higher concentration of proline may force the reaction back to glutanate with the resultant formation of inhibitory metabolites of the dicarboxylic acid type reported by Van Lanen, which would effectively recuce the formation of ribollavin.

Iysine and Beta-alanine also showed a moderate stimulation of riboflavin formation which is of interest since both have been shown to be related to aspartic acid which, as has been pointed out previously, may be closely related to riboflavin synthesis. Another possible explanation might be based on the fact that Iysine and Beta-alanine have a terninal anino group which might be a factor in ribonlavin synthesis. This appears to be the flrst time that Beta-alanine has been reported in connection with riborlavin synthesis. 
Threonine showed an appreciable effect on riboflavin forvation and this may result from 1ts relationship to aspartic acid, $\mathrm{Fla}$ homoserine. This was further verifled by the slight effect it had on reversing the histidine inhibition since some homoserine may be metabolized to methionine. The fact that isoleucine showed no stimulation of riboflavin synthesis tends to eliminate the formation of 1soleucine from threonine as a pathway of effect on ribollavin formation.

In the histidine inhibition mediun, the amino acids, serine and glycine, showed a stirulating effect on riboflevin formation which was rather curprising, since in previous experiments serine had not shown any effect on riboflavin synthesis in the GA medium. These data appear to substantiate the fact that serine and glycine are related in their metabo1isms. The effect of glycine or serine may indicate a closer relationship to riboflavin formation since the other anino acids which can be formed from glycine and serine do not show any signtflcant stimulation of rboflavin synthesis.

leucine showed the greatest stimulation of riboflavin formation, with an effect which seems to be separate from any of the other amino ac1ds, since there were no relationships with riboflavin stimulating amino acids noted. The effect of leucine on riboflavin formation may be more closely related to riboflavin aynthesis than any effects shown by the other riboflavin stimulating anino acids since it exerted the greatest effect.

An examination of the data seems to show that the amino acids, studied with respect to riboflavin synthesis, can be classified into three groups on the basis of their metabolic interrelationships and effect on 
riboflavin formation, namely, those related to aspartic acid, the glycine and serine group and the individual amino acid, leucine. It might be assumed that more than one amino ac1d may be involved in the formation of the larger amounts of riboflavin.

25. A Study of Special Anino Acld Media. The study of the effect of amino acids on riboflavin formation in the GAll medium offered information which might be used as a guide to develop a synthetic medium containing several anino acids. In prevlous experiments, the atternpts to combine a number of amino acids usually led to a noderate formation of mlboflavin or no appreciable yield at all, even though the growth was atisfactory. It was declded to test media containing almost all of the amino acids used in the preceeding experiment using concentrations generally based on those that appeared to be most efflcient for riboflavin formation. Since the actual stimulation of riboflavin formation caused by an amino acid is usually based on an increase over a control, the amounts of riborlavin produced above that in the CAll control mediun were used In the calculations. From the rields of mboflavin above that in the GAH mediun obtained by the addition of each concentration of amino acid to the CAll medium, a yield of riboflavin per $\mathrm{mg}$. of amino acid added vas calculated, to determine at which coneentration the added anino acid was most efficiently converted to ribollavin. The results of these calculations are shown in Table 37.

An anino acid base medium was prepared from the basal by adding certain concentrations of the antino acids listed in Table 37 as well as concentrations of L-arginine $\mathrm{HCl}$, Imalstidine $\mathrm{HCl}$ and L-methionine. The concentrations of the amino acids to be added were chosen, in most cases, 


\section{5}

TABLE 37

THE RESULTS OF CALCUIATIONS TO DETEFIINE THE RIBOHAVIN SYNTHSIZED PER MIIIIGRAM OF ANINO ACID ADDED TO THE GLUTAMTC ACID AROININE - HISTIDINE MIBDIUN

\begin{tabular}{|c|c|c|c|}
\hline \multirow[t]{2}{*}{ Amino Acid } & \multirow{2}{*}{$\begin{array}{c}\text { Concentration } \\
\text { Added } \\
(\mathrm{mg} / 100 \mathrm{ml})\end{array}$} & Riboflavin ${ }^{*}$ & \multirow{2}{*}{ of anino ac1d) } \\
\hline & & $(\mathrm{ug} / 100 \mathrm{ml})$ & \\
\hline Glyeine & $\begin{array}{r}5.0 \\
10.0 \\
20.0 \\
40.0\end{array}$ & $\begin{array}{l}140 \\
190 \\
350 \\
550\end{array}$ & $\begin{array}{l}28.0 \\
19.0 \\
17.5 \\
13.7\end{array}$ \\
\hline I-proline & 5.0 & 120 & 24.0 \\
\hline Ir-leucine & $\begin{array}{l}10.0 \\
20.0 \\
40.0\end{array}$ & $\begin{array}{l}100 \\
380 \\
850\end{array}$ & $\begin{array}{l}10.0 \\
19.0 \\
21.2\end{array}$ \\
\hline L-tyrosine & $\begin{array}{r}5.0 \\
10.0 \\
20.0 \\
40.0\end{array}$ & $\begin{array}{l}180 \\
220 \\
170 \\
260\end{array}$ & $\begin{array}{r}36.0 \\
22.0 \\
8.5 \\
6.5\end{array}$ \\
\hline DL-tryptophene & $\begin{array}{r}5.0 \\
10.0 \\
20.0 \\
40.0\end{array}$ & $\begin{array}{l}220 \\
180 \\
520 \\
420\end{array}$ & $\begin{array}{l}44.0 \\
18.0 \\
26.0 \\
10.5\end{array}$ \\
\hline L-lysine HCI & $\begin{array}{r}5.0 \\
10.0 \\
20.0 \\
40.0\end{array}$ & $\begin{array}{l}230 \\
330 \\
290 \\
400\end{array}$ & $\begin{array}{l}46.0 \\
33.0 \\
14.5 \\
10.0\end{array}$ \\
\hline L-cystine & $\begin{array}{r}5.0 \\
10.0\end{array}$ & $\begin{array}{l}450 \\
220\end{array}$ & $\begin{array}{l}90.0 \\
22.0\end{array}$ \\
\hline L-serine & $\begin{array}{r}5.0 \\
10.0 \\
20.0 \\
40.0\end{array}$ & $\begin{array}{l}550 \\
660 \\
680 \\
580\end{array}$ & $\begin{array}{r}110.0 \\
66.0 \\
34.0 \\
14.5\end{array}$ \\
\hline
\end{tabular}

(Table continued on following page) 
TABLE 37 (contimed)

\begin{tabular}{|c|c|c|c|}
\hline \multirow{2}{*}{ Amino Acld } & \multirow{2}{*}{$\begin{array}{c}\text { Concentration } \\
\text { Added } \\
(\mathrm{mg} / 100 \mathrm{mI})\end{array}$} & \multicolumn{2}{|c|}{ RIboflavin } \\
\hline & & (ug/100 ml) & (ug/mg of mino acid) \\
\hline L-threonine & $\begin{array}{r}5.0 \\
10.0 \\
20.0 \\
40.0\end{array}$ & $\begin{array}{l}280 \\
240 \\
540 \\
580\end{array}$ & $\begin{array}{l}56.0 \\
24.0 \\
27.0 \\
14.5\end{array}$ \\
\hline Lnalanine & 40.0 & 50 & 1.3 \\
\hline DL-phenylalanine & $\begin{array}{r}5.0 \\
10.0 \\
20.0 \\
40.0\end{array}$ & $\begin{array}{l}20 \\
40 \\
40 \\
70\end{array}$ & $\begin{array}{l}4.0 \\
4.0 \\
2.0 \\
1.8\end{array}$ \\
\hline DL-isoleucine & $\begin{array}{r}5.0 \\
10.0 \\
20.0 \\
40.0\end{array}$ & $\begin{array}{r}40 \\
30 \\
120 \\
120\end{array}$ & $\begin{array}{l}8.0 \\
3.0 \\
6.0 \\
3.0\end{array}$ \\
\hline L-valtine & $\begin{array}{r}5.0 \\
10.0 \\
20.0 \\
40.0\end{array}$ & $\begin{array}{r}20 \\
70 \\
70 \\
110\end{array}$ & $\begin{array}{l}4.0 \\
7.0 \\
3.5 \\
2.8\end{array}$ \\
\hline Beta-alanine & $\begin{array}{r}5.0 \\
10.0 \\
20.0 \\
40.0\end{array}$ & $\begin{array}{l}120 \\
290 \\
280 \\
300\end{array}$ & $\begin{array}{r}24.0 \\
29.0 \\
u_{1} .0 \\
7.5\end{array}$ \\
\hline
\end{tabular}

* Riborlavin in excess of GAH controls in Table 36.

from the data in Table 37 which shoved the concentrations giving the highest yield of mborlavin per mg. of amino acid, as recorded in the last colurn of the table except that none were used above $20 \mathrm{mg}$. per $100 \mathrm{ml}$. Certain deviations were mede with some amino acids because of prior knowledge of their effect on riboflavin formation and other information related to them. Glycine was added at a concentration of $10 \mathrm{mg}$. per $100 \mathrm{ml} .$, although the calculations in the above table indsate 
that $5.0 \mathrm{mg}$. per $100 \mathrm{ml}$. 18 more efricient, because it wes felt that this amino acid was truly involved in ribollavin formation. The concentration changes from the apparently most efficient values of any of the other andno acids were for somewhat aimilar reasons. The concentration of arginine HCl was increased to $20 \mathrm{mg}$. per $100 \mathrm{ml}$. because of the apparent importance of the basic amino acids in the riboflavin synthesizing metabolisn. The concentration of histidine HCl and methionine for the base medium was $5.0 \mathrm{mg}$. per $200 \mathrm{ml}$. since, in experiments mumber 19 and 24 , respectively, both of these amino acids showed some effect on growth at these concentrations and It was believed that concentrations higher than these might have proved detrimental to riboflavin formation. The composition of the amino acid base medium is shown in Table 38.

\section{TABLE 38}

THE MMINO ACIDS ADDED TO THE BASAL IN THE AMTHO ACID BASE MDIUS

\begin{tabular}{lclc}
\hline \multicolumn{1}{c}{ Amino Acid } & $\begin{array}{c}\text { Concentration } \\
(\mathrm{mg} / \text { /OO mI) }\end{array}$ & Amino Acid & $\begin{array}{c}\text { Concentration } \\
(\mathrm{mg} / 100 \mathrm{mI})\end{array}$ \\
\hline L-arginine HCI & 20.0 & L-leucine & 20.0 \\
L-alanine & 10.0 & L-Iysine HCI & 10.0 \\
Beta-alanine & 10.0 & L-methionine & 5.0 \\
L-cystine & 5.0 & L-proline & 5.0 \\
Glycine & 10.0 & DL-phenylalanine & 5.0 \\
L-histidine HCI & 5.0 & L-serine & 5.0 \\
L-threonine & 5.0 & DL-tryptophane & 2.5 \\
L-tyrosine & 5.0 & & \\
\hline
\end{tabular}


Eight media were prepared by adding different concentrations of the principal nitrogen sources, Inglutamic ac1d, L-espartic acld or asparagine to the amino acid base medium without methionine. A peptone control medium was prepared by adding $200 \mathrm{mg}$. of peptone to $100 \mathrm{mll}$. of the basal. A solution of methionine, for addition to the media after sterilization, was prepared and sterilized by Seltz filtration. Duplicate flask of media were sterilized, the required amount of methionine added to all flasks but the peptone controls and all Masks were Inoculated with a 28 hour washed cell suspension. The Inoculated Masks were incubated on the shaker for 4 days at $28^{\circ} \mathrm{C}$. After incubation, the dry velght of cells and colorimetric ribollavin values were obtained. These results and the concentrations of the principel nitrogen sources are shown in Table 39.

At the higher concentrations of the principel nitrogen sources, the riboflavin formed was lower in amount than the peptone medium in all except Nedium number 3 which contained agparagine only as the principal nitrogen source. When lower concentrations were used, the jleld of ribonavin was approximately the same as that in the peptone mediun, except again the asparagine medium, ledium number 6 , which showed considerably more riboflavin than the control. The data appear to show that the amino acids closely related to the citric acid cycle caused a decreased synthesis of riboflavin, at the higher concentrations. At the lower concentrations of these amino acids, the riboflavin could be synthesized more readily because there might be a lesser concentration of inhibitory products resulting from excesses of the principal nitrogen aources, since there was little differences in growth. Even though the principal 
窟

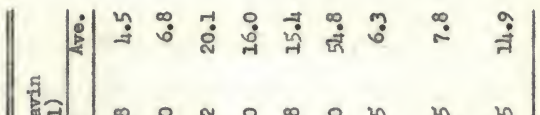

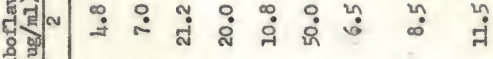

舫

㩆

본

밥ㅂ

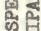

응

国

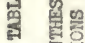

这鼠

늘

息

동

首

볼

是毸

똘봄

홍본

果

苞

|

:

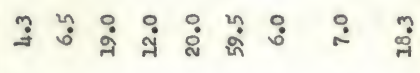

ผ.

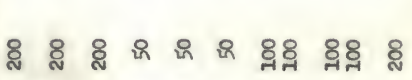

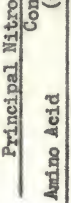

ซี 
nitrogen source was reduced by one-fourth in three of the media, there was no corresponding growth decrease which had been noted in an earlier experiment when the nftrogen supply was decreased in a medium which lacked anino acids. This was very good evldence that many of the anino acids were being effectively used for the synthesis of cellular material.

The highest yield of riboflavin occured in Hediun number 6 where $0.05 \mathrm{~g}$. of asparagine per $100 \mathrm{ml}$. of medium was the principal nitrogen source. This yield was more than three times that of the peptone control, even though they both contained approxdmately the same amount of total nitrogen. In these studies, this was the first instence that riboflavin was produced in a synthetic medium to give a higher yleld than the corresponding peptone medium of approximately the sane nitrogen content.

26. The Effect of L-serine on Riborlavin Synthesis in Glutemic Acid-Arginine and Gutemic Acid-Arginine-Hiatidine Media. Previous experiments had shown that serine had no effect on riboflavin formation in the CA mediu whereas in the GAH medium it stimulated riboflavin synthesis. Because these results were unexpected, this experiment was performed to verify the previlous results. The regular GA and GAll media were prepared with $0.21 \mathrm{~g}$. of glutanic acid per $100 \mathrm{ml}$. In the $\mathrm{GA}$ medium and $40 \mathrm{mg}$. of histldine $\mathrm{HCl}$ per $100 \mathrm{mll}$. of the $\mathrm{CA}$ medium to give the GAll medium. In addition, a second set of media were prepared in which the glutanic acid concentration was reduced to $0.05 \mathrm{~g}$. per $200 \mathrm{ml}$, which was the concentration in the histidine medium when serine stimuleted riboflavin formation. A concentration of $0.01 \mathrm{~g}$. of arginine HCl per $100 \mathrm{ml}$. was used for all the media. Other media were prepared by adding 28.0 mg. of serine per $100 \mathrm{ml}$. of the $\mathrm{GA}$ and GAH media of both glutantc 
acld concentrations. Glycine controls were also prepared by adding 20.0 mg. of glycine per $100 \mathrm{ml}$. of each $\mathrm{CA}$ and $\mathrm{GAH}$ media. Duplicate flasks of sterile media were inoculated with a 28 hour washed cell suspension and Incubated for 4 days at $28^{\circ} \mathrm{C}$. on the shaker. The dry weight of cells and the colorimetric determinations of riboflavin that were made and the concentrations of glutamic acid are shown in Table 40 .

TABLE 40

THE ETFECT OF SERTNE ON RTBOFLAVIN FOHNATION IN GLUTAMIC ACID ARGIHINE (GA) AMD GLUTANIC ACID - AROININB - HISTIDINE (GAH)

MEDIA WITH DIFFERTI CONCENTEATIOHS OF GLUTAMIC ACID

\begin{tabular}{|c|c|c|c|c|c|c|c|}
\hline \multirow[t]{2}{*}{ Medium } & \multirow{2}{*}{$\begin{array}{l}\text { Glutenic Ac1d } \\
\text { Added } \\
\text { (g/100 ml) }\end{array}$} & \multicolumn{3}{|c|}{$\begin{array}{c}\text { Dry Weight Cells } \\
(\mathrm{mg} / 20 \mathrm{ml})\end{array}$} & \multicolumn{3}{|c|}{$\begin{array}{c}\text { RiborIevin } \\
\text { (ug/ml) }\end{array}$} \\
\hline & & 1 & 2 & Ave. & 1 & 2 & Ave. \\
\hline $\mathrm{CA}$ & 0.21 & 72.8 & 62.4 & 67.6 & 1.0 & 1.2 & 1.1 \\
\hline GAA & 0.21 & 1.6 & 2.4 & 2.0 & 4.0 & 4.5 & 4.3 \\
\hline GAOIy & 0.21 & 67.0 & 55.6 & 61.3 & 111.0 & 9.3 & 10.2 \\
\hline GAHEIy & 0.21 & 1.6 & 2.4 & 2.0 & 11.8 & 10.0 & 10.9 \\
\hline GASerine & 0.21 & 50.2 & 46.2 & 48.2 & 1.2 & 1.2 & 1.2 \\
\hline GAHSerine & 0.21 & 2.6 & 1.8 & 2.2 & 6.8 & 6.5 & 6.7 \\
\hline GA & 0.05 & .22 .9 & 12.2 & 12.6 & 0.5 & 0.5 & 0.5 \\
\hline CAAB & 0.05 & 1.4 & 1.0 & 1.2 & 4.3 & 4.0 & 4.2 \\
\hline GAOLy & 0.05 & 12.1 & 9.9 & 111.0 & 5.0 & 8.5 & 6.8 \\
\hline CAHCIy & 0.05 & 2.0 & 1.0 & 1.0 & 7.5 & 8.3 & 7.9 \\
\hline CASerine & 0.05 & 21.4 & 5.0 & 8.2 & 0.5 & 0.8 & 0.7 \\
\hline GAHSerine & 0.05 & 1.0 & 1.0 & 1.0 & 5.3 & 5.3 & 5.3 \\
\hline
\end{tabular}


The results of this experiment conflrm the previous findings and did show that serine stimulated riboflevin formation in the GAH medium, whereas, it did not show this effect under growth conditions In the GA medium. The data showed that glycine was more effective than serine in stimulating riboflavin formation in either media which may Indicate that in the GAF mediun with serine, the serine was converted to glycine rather than the reverse. In the rapldly growing medium the concentration of glycine that may be formed from serine may nevor reach the value necessary for riboflavin formation but in the inhibition mediun, a sufficlent concentration of glycine may be reached since the glycine can not be used for growth and thus is avallable for riboflavin synthesis. These results further establish the usefulness of the histidine inhibited medium for studies of riboflavin synthesis, and that the addition of serine to media may also be helpful.

\section{The Effect of Different Concentrations of Asparagine on} Growth and P1boflavin Formetion in a Peptone Nedium. Asparagine, the amide of aspartic acid, may be associated with the biosynthesis of riboflavin since previous experiments have shown that the greatest atimulation of riboflavin formation occured in media containing this corrpound. In order to test this possibility further, different concentrationa of asparagine were added to a peptone mediun composed of $0.2 \mathrm{~g}$. of peptone per $100 \mathrm{ml}$. of the basal. Duplicate flasks of the sterilized media were Inoculated with a 28 hour washed cell suspension and incubated on the shaker for 4 days at $28^{\circ} \mathrm{C}$. The dry weight of cells and the colorimetric ribohavin values were deterroined. These values and the concentrations of asparagine added are shown in Table 47. 
TABLE 41

THE EFFECT OF DIFFERET CONCENTRATIONS OF ASPARAGTNE ON GROWTH AND RIBOFTAVIN FORMATION IN A PEPTONE MEDIUI

\begin{tabular}{|c|c|c|c|c|c|c|}
\hline \multirow{2}{*}{$\begin{array}{l}\text { Asparagine } \\
\text { Added } \\
(\mathrm{mg} / 100 \mathrm{ml})\end{array}$} & \multicolumn{3}{|c|}{$\begin{array}{c}\text { Dry Woight Cells } \\
(\mathrm{mg} / 20 \mathrm{ml})\end{array}$} & \multicolumn{3}{|c|}{$\begin{array}{l}\text { Biboflavin } \\
\text { (ug/ml) }\end{array}$} \\
\hline & 1 & 2 & Ave & 1 & 2 & Ave. \\
\hline $0^{*}$ & 88.2 & 78.4 & 83.3 & 18.5 & 13.0 & 15.8 \\
\hline 2.5 & 82.8 & 79.6 & 81.2 & 36.3 & 33.5 & 34.9 \\
\hline 5.0 & 83.0 & 84.8 & 83.9 & 34.6 & 30.0 & 32.3 \\
\hline 10.0 & 65.0 & 80.2 & 72.6 & 27.6 & 22.0 & 24.8 \\
\hline 20.0 & 94.2 & 66.6 & 80.0 & 17.0 & 25.6 & 21.3 \\
\hline 40.0 & 86.2 & 78.2 & 82.2 & 111.0 & 8.8 & 9.9 \\
\hline
\end{tabular}

* Peptone control.

The addition of only $2.5 \mathrm{mg}$. of asparagine per $100 \mathrm{ml}$. of the peptone mediun resulted in riboflavin yleld which was more than double thet found in the peptone medium alone. These data further substantiate the relationship of asperagine to the formation of miborlavin in $A$. gossypif. Asparagine may itself be related to the synthesis or it may be involved in the formation of some other compound which is involved In the synthesis process. The formation of riboflavin was inhibited when $40 \mathrm{mg}$. of asparagine was added to $100 \mathrm{ml}$. of the peptone medium, which was probably the same sort of an effect which was noted when the glutamic acid medium was adied to peptone. The addition of even high concentrations of asparagine to the peptone mediun fafled to cause any significant change in the growth of the organism which was further 
evidence that asparagine must function very closely to the riboflavin synthesizing metabolism of A. gossypic. In studyling biosynthesis pathways for riboflavin in media supporting growth and riboflavin formation, further research on addition of asparagine might yield useful information. 


\section{SUDAARY AND CONCLUSTONS}

Studies on the growth and riboflavin metabolism of Ashbye gossypil were undertaken in an effort to galn more facts pertaining to the mechanism of riboflevin synthesis in microorganiams and thereby bring about a more complete understanding of the pathway and intermediates participating in the synthesis.

During these studies the circular chromatographic technigue was Introduced and its utility demonstrated in conjunction with the rapid, qualltative chromatographic separation of unknown mixtures. The observed $R_{P}$ values of anino acids and peptides were reported for the n-butanolacetic acid-water and pyrldine-tertiary anyl alcohol-water solvents enploying the circular chromatographic technique. The use of this technique in relation to further studies on the metabolism of $\mathrm{A}$. gossypif is indicated.

A colorimetric method for the analysis of riboflavin was developed in order to provide a more rapid assay of the results obtained in the different experiments. This method, although not as accurate as the fluorometric method, did give indications that it covld be refined further, for use as a quantitative method for riboflavin determinations, especially in culture media for the study of rboflavin synthesis, where there is only a mell amount of Interferring substances present. A check of the method showed reasonable recoveries of added riboflavin in unknown samples could be obtained, further deronstrating that the method could be used 
for approximate est1 ations of rboflavin formation.

The ribolavin formation by A. gossypli in a yeast extract-peptone nediun was shown to occur almost entirely after the organtsm had reached meximum growth. The formation of riboflavin. in the medium was also accompanied by an increase In pH of the medium, the pH having reached a minimum value at approximately the age of maxdrum growth. During the Initial pheses of growth, the organism must epparently have to procuce some special conditions andor intermediates for the formation of ribom flavin, since the morphology of the organism showed marked changes during this period.

The complex nftrogen source, peptone, was frectionated on a powdered cellulose column, using a n-butanol-acetic acld-water solvent, and the resulting fractions tested for growth and ribollavin formation with A. gossypi1. AII, except one, of these fractions gave good growth of the organian; however, only one fraction gave good growth and allowed the formation of appreciable riboflavin. The chromatographic analysis of the hydrolyzate of this riboflavin stimulating fraction indicated that there was a predominance of basic anino acids present, as well as dicarboxylic amino acids. A study of the possible amino acids present in this fraction resulted in the development of a synthetic medium, containing glutamic acid and arginine as the nitrogen sources, which sup-

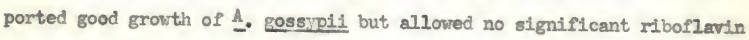
formation.

Since the inocula for these studies were prepared from cells grown on yeast extract-peptone stock agar slants, the possibility of substances being carried over in the inoculations was investigated by a series of 
studies involving the serial transfer of cells, on solid and in 11quid, natural and synthetic media. It was apperent that some factor or factore were being carrled over from the yeast extract-peptone agar slent in the first transfer; however, in subsequent transfers the factor or factors seemed to have been diluted out to a point where there was little effect. Although this carry over effect cannot be overlooked, the effect of $1 t$ should be rather constent under any one particular set of experimental conditions and the results of a particular experiment can be discussed with respect to added known factors.

Aqquecus cell extracts of A. gossypil, obtained by grinding the cells in a mall amoust of distilled water with ground glass and sand, were shown to stirulate miboflavin synthesis in a synthetic medium containing glycine. This stimulation effect was shown to be present principally in older cells, since the effect was demonstrated with 132 hour cells but could not be demonstrated with 84 hour cells from the same growth medium. The possibility of enzymes or enzyme systems being introduced in the aqueous cell extract was ellminated by autoclaving of the media to which the extracts had been added. The chromatographic separation on filter paper strips and the subsequent testing of the fractions found indicated that the factor or factors in the aqueous cell extract, which stimulated riborlavin formation, did not migrate in the butanol-acetic acid-water solvent system.

The addition of relatively large concentrations of glutamic acid. or asparagine to a peptone medium resulted in the decreased formation of mboflavin and a corresponding 1ncreased growth. The results of many of the experiments show this inverse relationship between growth and 
riboflavin formation which probably indicates that conditions for good growth of the organism might not be conditions for good riboflavin synthesis.

Other nitrogen sources were tested for growth and riboflavin formation with $\mathrm{A}$. gossypil and 1t was found that $\mathrm{NH}_{4} \mathrm{NO}_{3}, \mathrm{KNO}_{3},\left(\mathrm{NH}_{4}\right)_{2} \mathrm{SO}_{4}$, amonium acetate, armonium cltrate and urea would not serve as single nitrogen sources for elther growth or riboflavin formation. The presence of relatively high concentrations of nitrate ions in a peptone medium was found to be inhibitory to the formation of riboflavin by 1 . gossypis, but apparently had no effect on the growth of the organdson.

In synthetic media with glutamic acid, aspartic acid or agparagine as the principal nitrogen sources, the addition of glycine resulted in an increased formation of riboflavin, especially in the presence of aspartic acid or asparagine. The addition of L-serine or DL-threonine, Instead of glycine, to the same media resulted in no increased riboflavin formation. Under the conditions used, it appeared that the synthesis of rlboflavin was more closely associated with aspartic acid than glutamic acid and that glycine vas associated in some way with the formation of ribonavin.

The addition of L-histidine HCI to a synthetic medium contrining glyeine had a varied effect on growth and riboflavin formation by 1 . gossypil. In low concentrations, $2.5 \mathrm{mg}$. to $10.0 \mathrm{mg}$. per $100 \mathrm{ml}$., it had a stimulatory effect on growth which was accompanied by a slight decrease In formation of riboflavin; however, at higher concentrations, $25.0 \mathrm{gg}$. to $40.0 \mathrm{mg}$. per $100 \mathrm{ml}$., It Inhibited the growth of the organism but ald not inhibit the formation of riboflavin. By this inhibition effect, 
the growth metabolisn of the organism and the ribollavin gynthesizing metabolism had been apparently separated. When imidarole, a compound making up part of the histidine molecule, was added, in the same approxdmate concentrations as histidine, to the synthetic media without histidine, no inhibition of the organism was noted.

A system of histidine inhibited cells of 1 . gossypil was used to study the effects of 15 amino acids on riboflavin synthesis and growth. The amino acids, glyeine, proline, tyrosine, alphamalanine, betamalanine, phenylalanine, isoleucine or valine had no effect on the growth of the organism In the presence of histidine; however, the amino acids leucine, tryptophane, lysine, serine and threonine did relleve the histidine inhibition slightly, usually at the highest concentrations used. The anino aclds cystine and methiontne relieved the inhibition of histidine which seemed to relate the inhibition by histidine to the metabolism of the sulfur containing anino acids. The arino acids alphamalanine, phenylalanine, 1soleucine, valine and methionine showed no effect on riboflavin synthesis in the histidine inhibited cell aystem, whereas proline and tyrosine showed a slight effect and cystine, lysine, tryptophene and beta-alanine showed a moderate effect. The greatest effect on riboflevin formation was shown by the amino acids glycine, serine, threonine and leucine, with leucine showing the most effect of the four amino acids listed.

A synthetic medium containing 17 different anino acids was found to allow the production of considerable riboflavin and permitted good growth of $\Lambda$. gossipi1. The riboflavin formed was over three times that formed in a peptone medium of approximately the sane percentage nitrogen. 
140

This study of the metabolism of riboflavin in Ashbya gossyoli has pointed out that the biosynthesis of riboflavin is related to many factors. It appears that the synthesis of mbollavin can be placed into three different group functions as followss one, aspartic acid and those conpounds related to 1t, two, glyelne and serine, and three, leucine.

Various conditions have been developed which permit the study of the netabolism of $\mathbb{\Lambda}$. gosspil under different circumstances, namely, growth with iftle or no riboflavin formation, growth with different degrees of riboflavin formation and no growth with riboflavin formation. It is evident that further work, auch $a$, studies of radio active tracers, short time chromatographic analyses, amino acid antagonists, the mechanisus of histidine Inhibition, etc., must be done in order to more completely understand the pathways of riboflavin synthesis in microorganiams. 


\section{BIBLIOGRAPIIY}

1. Abelson, P. H., J. Blol. Chem., 206, 335 (1954).

2. Abelson, P. H., Bolton, E. T., Aldous, E., J. B101. Chenn., 198, $173(1952)$.

3. Abelson, P. H., Vogel, H. J., J. Biol. Chem., 213, 355 (1955).

4. Ames, B. N., M1tchell, H. K., J. Am. Chem. Soc., IL, 252 (1952).

5. Anderson-Kotto, I., Ehrensvard, G., Hogstrom, G., Relo, L., Seluste, B., J. Blol. Chem., 210, 455 (1952).

6. Association of Vitamin Chemists, METHODS OF VIMAMIN ASSAY, Intersclence Publishers, Inc., New Tork, (19;1) 2nd Ld. p. 166.

7. Black, S., Gray, N. H., J. Am. Chem. Soc., 75, 2271 (1953).

8. Black, S., Wright, N. G., J. Am. Chen. Soc., 75,5766 (1953).

9. Broquist, II. P., Snell, E. E., J. Biol. Chem., 180, 59 (1949).

10. Brom, E. G., Goodvin, T. W., Pendlington, S., Biochem. J., G],

11. Buston, H. W., Kasinathkn, S., Wylie, S. K., Am. Botany N. S., 2. 373 (1938).

12. Buston, H. W., Pramanik, S. N., Blochen. J., 25, 1656 (1931).

13. Chin, C. J., Fermentation Technol. (Japan), 25, I40 (1947).

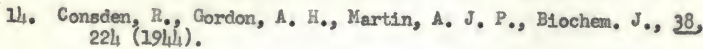

15. Cutinelli, C,, Ehrensvard, O., Redo, L., Saluste, E., Stjernholm, R., Acta Chem. Scand., 5, 353 (1951).

16. Davls, B. D., J. Biol. Chem. 191, 315 (1951).

17. Dav1s, B. D., Nature, 169, 534 (1952).

18. Davis, B. D., Science, 138, 251 (1953). 
19. Davis, B. D., Adv. Enzymology, 16, 24,7 (1955).

20. Delusk, A, O., Wagner, R, P., J. Am. Chem. Soc., 75, 5131 (1953).

21. Deseive, E., Milchwissenschaft, 2, 1/4 (1947).

22. Dilkanshaya, E. M., Mikrobiologiya, 22, 256, 525 (1953).

23. Dikanshaya, E. N., Trudy Inst. Mikrobiol., Akad, Nauk. S. S. S. R., 3. 35 (1954).

24. Dulaney, E. L., Grutter, F. H., Myeologia, 42, 717 (1950).

25. Ehrensvard, G., Reio, I., Saluste, R., Stjernholn, R., J. Blol. Chem., 189, 93 (1951).

26. Elinger, P., Koschara, W., Ber., 66, 315 (1933).

27. Farries, E. H. M., Bell, A. F., Ann. Botany, 岁, L,23 (1930).

28. Fries, N., Symbolee Botan. Upealienses III, 2 (1938).

29. Fries, N., Proc. IV, Intern. Congress Microbiol., Copenhagen 385 (1949).

30. Gale, E. F., Blochem. J., 32,1583 (1938).

31. Gale, E. F., Adv. Enzymology, 6, 1 (1946).

32. Gilvarg, C., Davis, B. D., Fed. Proc., 13, 24?, (1954).

33. Airi, K. V., Krishnaswamy, P. R., J. Bact., 67, 309 (1954).

34. Goldberger, J., Lillie, R. D., U. S. Publie Health Fot., 4l, 1025 (1926).

35. Coodwin, T. W., Pendilington S., Blochen. J., 57, 631 (1954).

36. Green, D. E., Leloid, I. F., Nocito, V., J. B1ol. Chem. 161, 559 $(1945)^{\circ}$.

37. Gut1lermond, A., Fontaine, M., Raffy, A., Compt. rend., 201, 1077 (1935).

38. Haas, F., Mitchell, K. B., Anes, B. N., Lichell, H. K., Genetics, 37. $215(1952)$.

39. Hodson, A, Z., Norris, L. C., J. B101. Chem., 131, 621 (1939).

40. Horowitz, N. H., J. B101. Chem., 171, 255 (1947). 
41. Lampen, J. O., Roepke, R. R., Jones, M. J., Arch. Biochen., 13, $55(1947)$.

42. Levintow, L., Meister, A., J. Biol. Chem., 209, 265 (1954).

43. Low, B. W., Acta Chem. Scand., 4, 294 (1950).

44. Karrer, P., Schopp, K., Benz, F., Helv. Chtm. Acta, 18, 426 (1935').

45. Klungsoyr, L., Acta Chem. Scand., 8, 723 (1954).

46. Mungsoyr, I., Acta Chem. Scand., 8, 1292 (1954).

47. Kogl, F., Fries, N., Z. physiol. Chem., 24, 93 (1937).

48. Kritrmann, M. G., J. Biol. Chem, , 167, 77 (1947).

49. Kohn, R., Gyorgy, P., Wagnex-Jauregg, T., Ber., 66, 317, 576 (1933).

50. Maciaren, J. A., J. Bact., 63, 233 (1952).

51. Nellutt, W. S., J. Biol. Chem., 210, 511 (1954).

52. Mcliutt, W. S., J. Blot. Chem., 219, 365 (1956).

53. Meyer, R. L., Rodbart, M., Arch. Biochem., 11, 49 (1946).

54. Keister, A., Adv. Enzymology, 16, 185 (1955).

55. Meister, A., Fraser, P. E., J. B1ol. Chem., 210, 37 (1954).

56. Xinoura, K., J. Fermentation Technol. (Japan), 28, 186 (1950).

57. Minoura, K., J. Fermentation Technol. (Japan), 22, 44L (1951).

58. Kinoura, X., Vitamins (Japan), 6, 62 (1953).

59. Mirimanoff, A., Raffy, A., Compt. rend., 206, 1507 (1938). 60. Noore, $\mathrm{H}_{\text {. N N. }}$, deBecze, O., Schraffenberger, E., J. Bact., 53

61. Nielsen, N., Ljungdahl, L., Sandegren, E., Nature, 164, 1055 (1949).

62. Peltier, A. S., Borchers, R., J. Bact., 近 519 (19L7).

63. Phelps, A. S., U. S. Patents 2,473,817; 2,473,818 (1949).

4. Plerpoint, W. S., Hughes, D. E., B1ochen. J., 56, 130 (1954). 


\section{4}

65. Pinl, A., Fritzson, P., J. B101. Chem., 215, 345 (1955).

66. Plaut, G. V. E., Fed. Proc., 13, 274 (1954).

67. Plaut, G.W. F., J. B1ol. Chem, , 208, 513 (1954).

68. Plaut, G. W. E., J. Biol. Chem., 211, 111 (1954).

69. Plaut, G. W. E., Broberg, P. L., J. Biol. Chem., 212, 131 (1956).

70. Pontorich, V. E., Biokhimiya, 8, 297 (1943).

7. Pridhan, T. G., U. S. Patent 2,578,738 (1951).

72. Pridham, T. A., Raper, K. B., Mycologia, 42, 603 (1950).

73. Pridham, T. G., Raper, K. B., Mycologia, 44,452 (1952).

74. Rafelaon, K. E., Ehrenevard, G., Bashford, N., Saluzte, E., Heden, c. G., J. Biol. Chem., 217, 725 (1954).

75. Raffy, A., Compt. rend. soc. biol., 126, 875 (1937).

76. Raffy, A., Fontaine, M., Compt. rend., 205, 1005 (1937).

77. Ratner, S., Mdv. Enzymology, 15, 319 (1954).

78. Ratner, S., Anslow, W. P., Petrack, B., J. Biol. Chen., 204, 115 (1953).

79. Ratner, S., Petrack, B., Rochovansky, O., J. B101. Chem $v \underline{201}, 951$ (1953).

80. Ravel, J, M., Felsing, B., Shive, W., J. Biol. Chem., 206, 791 $(1954)$.

81. Reneud, J., Lachaux, K., Compt. rend., 219, 498 (1944).

82. Renaud, J., Lechaux, M., Compt. rend., 221, 18i (1945).

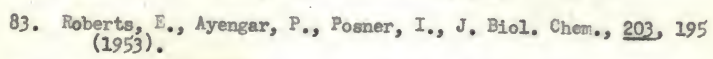

84. Rose, W. C., Osterling, M. J., Womack, $\mathrm{H}_{\bullet}, \mathrm{J}$. B1ol. Chem., 175 ,
753 (1948).

85. Rothotein, K., Kinler, L. L., J. BLol. Chem., 208, 243 (1954).

86. Iudert, I. J., U. S. Patent 2,347,503 (1945).

87. Rutter, L., Nature, 161, 435 (2948). 
88. Rutter, L., Analyst, 25, 37 (1950).

89. Schopfer, W. H., Helv. Chim. Acta, 27, 1017 (1944).

90. Schopfer, W. H., Z. V1taminforsch., 16, 106 (1945).

91. Schopfer, W. H., Gullloud, N., Experientia, 1, 22 (1953).

92. Shemin, D., Russell, C. S., J. Am. Chem. Soc., 75, 4873 (1953).

93. Slotte, K. H., Primosigh, J., Nature, 168, 696 (1951).

94. Snell, I. I.., Strong, F. M., Ind. End. Chen., Anal. Ed., II, 346 (1939).

95. Srb, A, N., Horowitz, N. H., J. Blol. Chenn, 154, 129 (1944).

96. Srinivasan, P. R., Sprecher, M., Sprinson, D. B., Fed. Proc., 13, $302(1954)$.

97. Strassman, $M_{\text {, }}$ Welnhouse, 8., J. Am. Chem. Soc., 75, 1680 (1953).

98. Sutton, W. B., Werknan, C. H., Arch, Blochem. B1ophys., 47, 1 (1953).

99. Tanner, F. W., Vojnovich, C., Van Lanen, J. Y., Sclence, 101, 180 (19l.5):

100. Tanner, F. W., Vojnovich, C., Van Lanen, J. M., J. Bact., 58, 737 (1949).

101. Tatum, E. I., Schemin, D., J. Biol. Chem., 209, 671 (1954).

102. Tatum, E. L., Gross, S. R., Ehrensvard, G., Garnjobst, L., Proc. Mat1. Acad. Sc1. U. S., L0, 271 (1954).

103. Tswett, M., Ber. deut, bot. Ges., 24, 384 (1906).

104. Van Eekelen, M., Emerie, A., Acts Brevla Neerland., 6, 136 (1937).

105. Van Lanen, J. X., Smiley, K. I., Stone, I., U. S. Patent 2,666,014 $\left.(195)^{4}\right)$.

106. Vogel, J. J., Abelson, P. H., Bolton, E. T., Blochem, Blophys. Acta, 11, 584 (1953).

107. Vogel, H. J., Davls, B. D., J. Am. Chem. Soc., Il, 109 (1952).

108. Von Fuler, H., Karrer, P., Nalmberg, M., Schopp, K., Benz, F., Fre1, P., Helv. Chim. Acta, 18, 522 (1935). 
109. Von Euler, B., Malmberg, M., Z, physiol. Chem., 250, 158 (1937). 110. Wahbe, A. J., Shive, W., J. Biol. Chem., 211, 155 (1954). 111. Wang, C. H., Christensen, B. E., Cheldelin, V. H., J. Biol. Chem., 213, $365^{\circ}$ (1955).

112. Webster, G. C., Varner, J. E., J. Am. Chem. Soc., 76, 633 (1954). 113. Wickerham, L. J., Neckinger, M. H., Johneton, R. M., Arch. Blochem., 2, 95 (1946).

114. Windsor, E., J. Blol. Chem., 192, 607 (1951).

115. Wolf, 0., J. B101. Chem., 200, 637 (1953).

116. Woods, L., Ravel, J. K., Shive, W., J. B101. Chem., 209, 559 (1954). 117. Tamasakt, I., Yositome, W., B1ochem. 2., 297398 (1938).

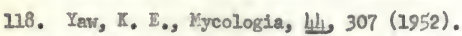


The writer was born on July 12, 1921 in Cincinnati, Ohio. His early education was obtalined through the Public School System of Cincinnati, Ohio. He served as a comnissioned officer with the United States Korine Corps during World War II. He pursued his undergraduste studies at the Univeraity of Cincinnati, The University of Tampa and the University of Florida, receiving the Bachelor of Sclence Degree, with honors, from the Unitersity of Florida in August, 1949.

He contimued graduate studies in Biochemistry at the University of Florida and received the Degree of Master of Science In February, 1951. He attended Purdue University Proin February, 1951 to August, 1952, Aoing graduate work in bacteriology. He returned to the University of Florida In September, 1952; as an Assistant in Regearch at the Engineering and Industrial Experiment Station. He becane a teaching assistant in the Chenistry Department of the University of Florida in February, 195h, serving in that capacity unt11 he wes awerded the Tennessee Eastman Kodak Research Fellowship in September, 1955. After his return to the University of Florlda in 1952, he pursued graduate studies in biochemistry leading to the Degree of Doctor of Philosophy in Chemistry.

He is a member of Phi Kappa Phl, Phl Sigma Blological Society, Sigma $X_{1}$, the Anerican Chemical Society and the Americen Association for the Advancement of Science. 
Th1s dissertation was prepared under the direction of the chairman of the candidate's supervisory comnittee and has been approved by all members of the comittee. It was submitted to the Dean of the College of Arts and Sciences and to the Gractuste Council and was approved as partial fulfiliment of the requirements for the degree of Doctor of Philosophy.

June 4,1956

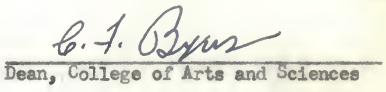

Dean, Graduate School

SUPERISORY COMITTEE:
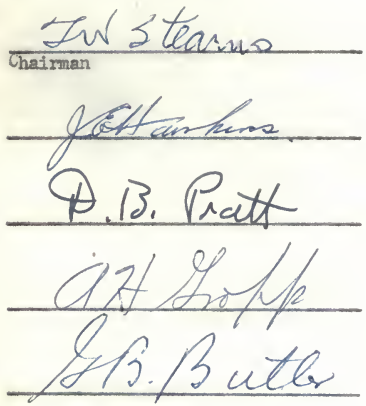